Aus dem Institut für Humangenetik

(Prof. Dr. med. Dr. h. c. W. Engel)

im Zentrum Hygiene und Humangenetik

der Medizinischen Fakultät der Universität Göttingen

\title{
Molekulargenetische Untersuchungen des SPG31-Gens bei der Hereditären Spastischen Paraplegie
}

\author{
Inaugural-Dissertation \\ zur Erlangung des Doktorgrades \\ der Medizinischen Fakultät \\ der Georg-August Universität zu Göttingen
}

vorgelegt von

Saskia Wedegärtner

aus Bad Driburg

Göttingen 2013 
Dekan:

1. Berichterstatter:

2. Berichterstatter:

Tag der mündlichen Prüfung:
Prof. Dr. rer. nat. H. K. Kroemer

Prof. Dr. med. Dr. h.c. W. Engel

Prof. Dr. med. E. Wilichowski

21.10.2014 


\section{Inhaltsverzeichnis}

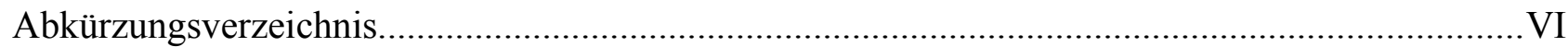

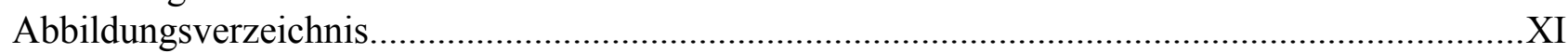

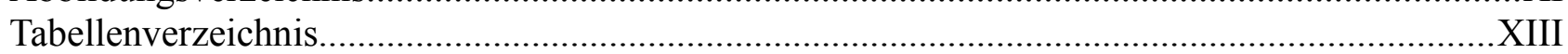

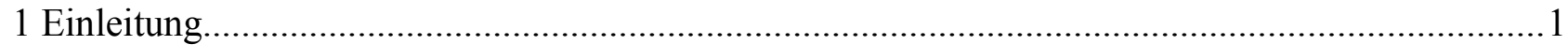

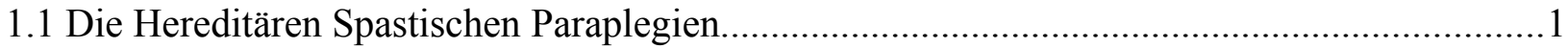

1.2 Genetik der Hereditären Spastischen Paraplegien............................................................

1.3 Pathomechanismen der Hereditären Spastischen Paraplegien..............................................5

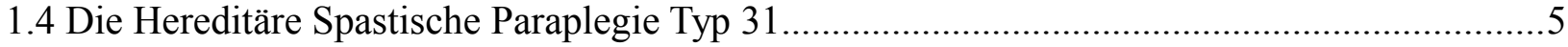

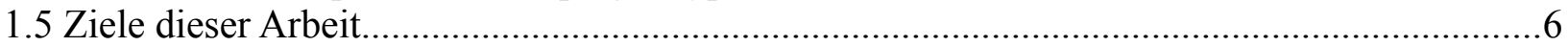

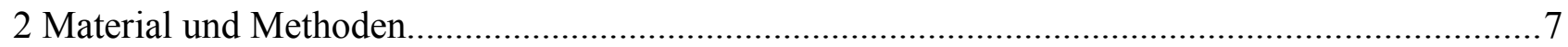

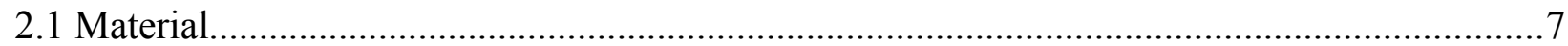

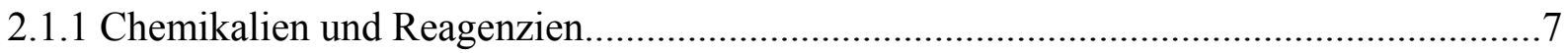

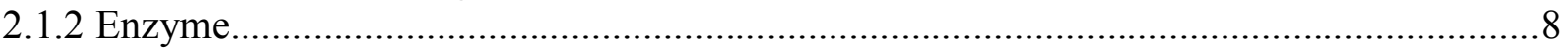

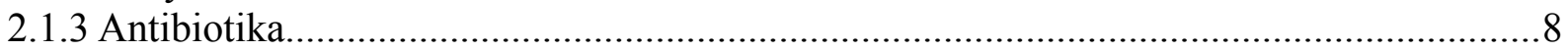

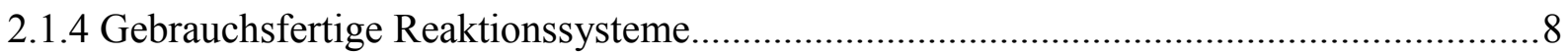

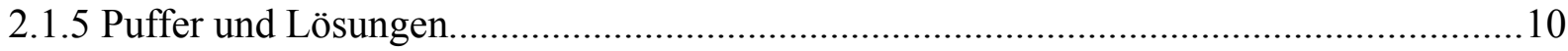

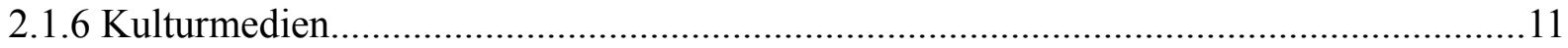

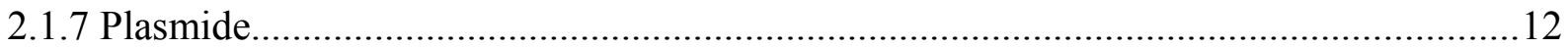

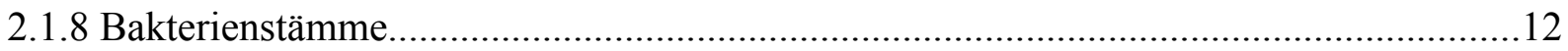

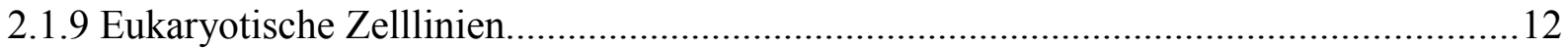

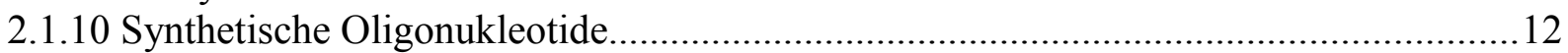

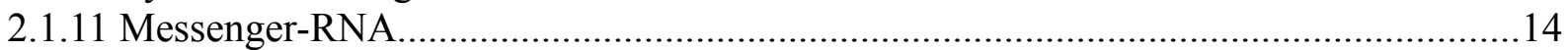

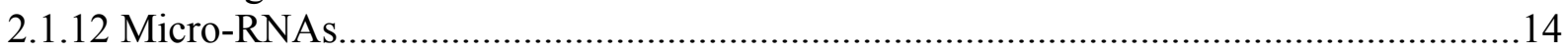

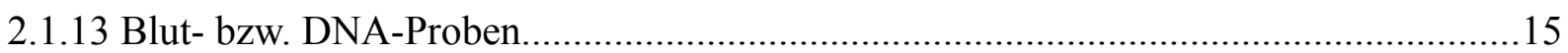

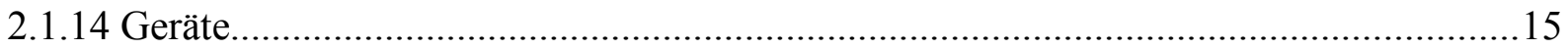

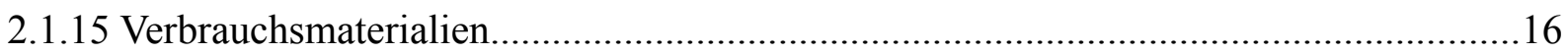

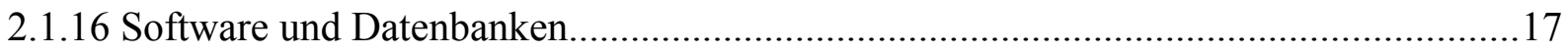

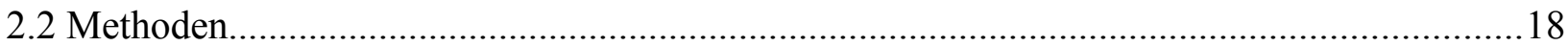

2.2.1 DNA-Präparation aus Leukozyten des peripheren Blutes..........................................18

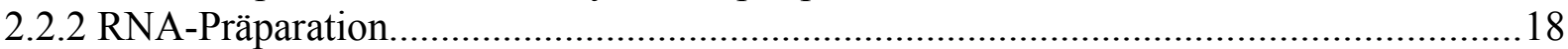

2.2.2.1 Isolation von Gesamt-RNA aus Leukozyten des peripheren Blutes mithilfe der

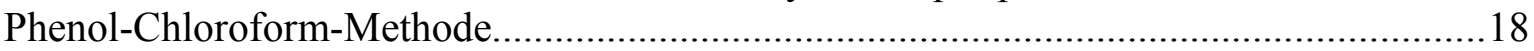

2.2.2.2 Isolierung von Gesamt-RNA aus Zellen der Mundschleimhaut und des Speichels. 19

2.2.2.3 Isolierung von Gesamt-RNA aus Epithelzellen im Urin......................................20

2.2.2.4 Isolierung von Gesamt-RNA aus Haarwurzeln...............................................20

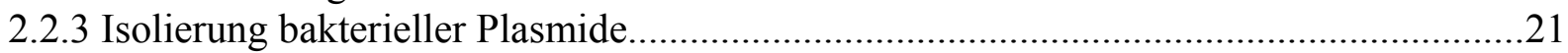

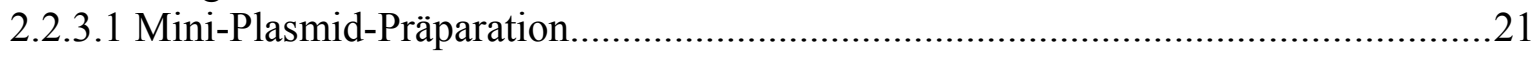

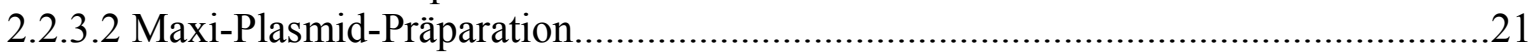

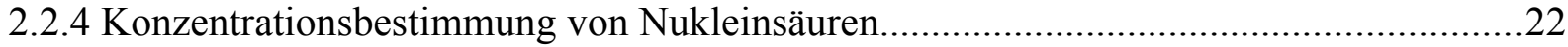

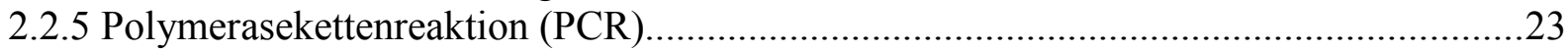

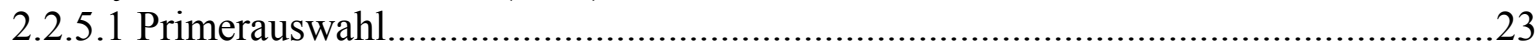

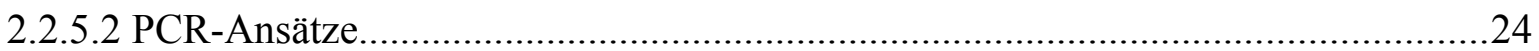

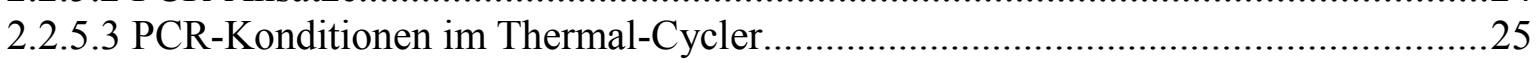

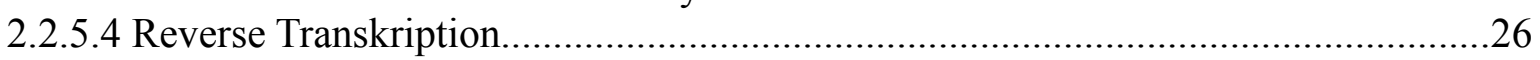

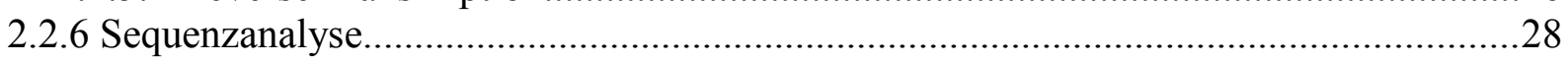

2.2.7 Multiplex Ligation-dependent Probe Amplification (MLPA) .....................................29

2.2.8 Auftrennung von DNA-Fragmenten mittels Agarosegel-Elektrophorese ........................30 


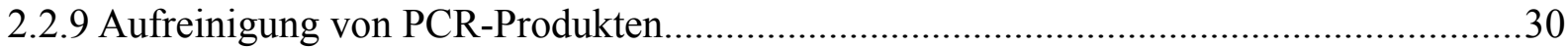

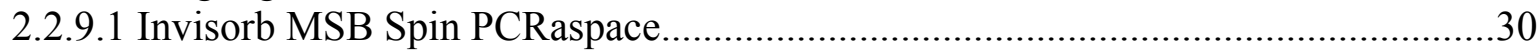

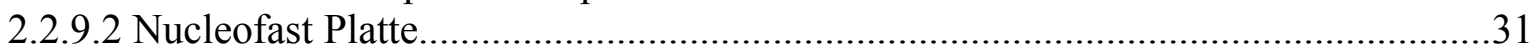

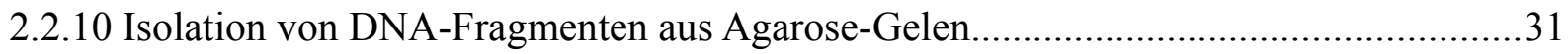

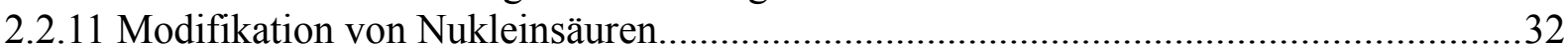

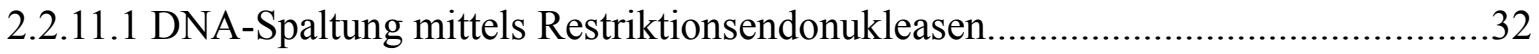

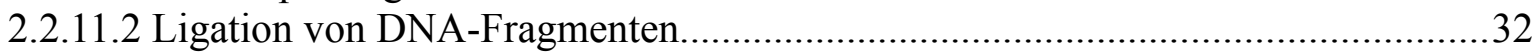

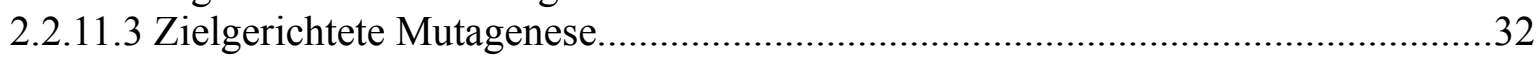

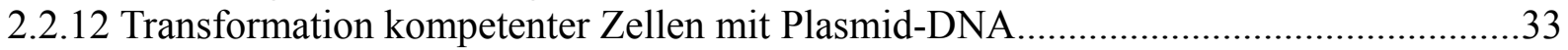

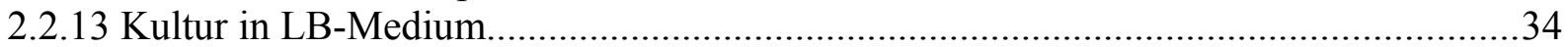

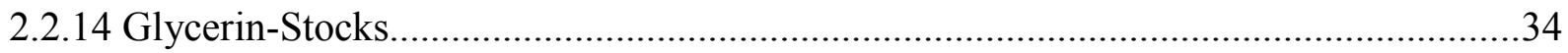

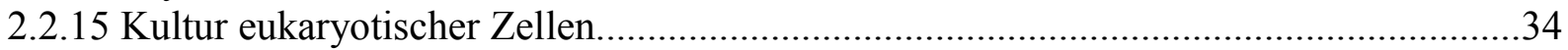

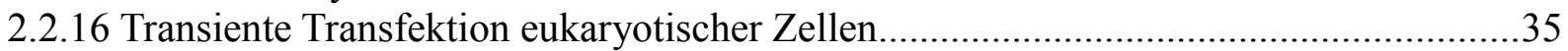

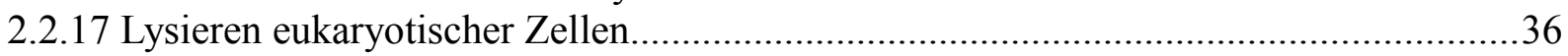

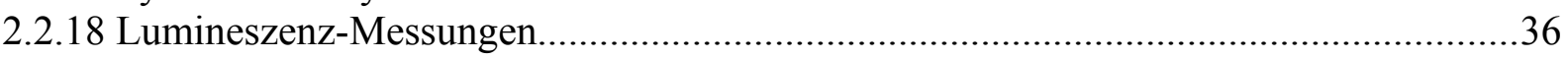

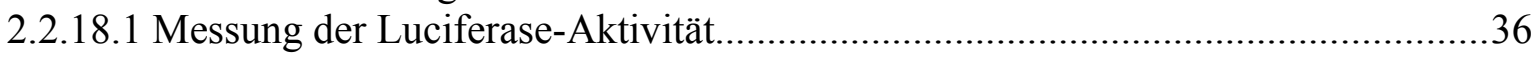

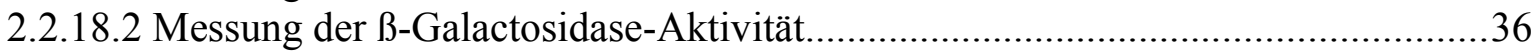

2.2.18.3 Auswertung der Lumineszenz-Messergebnisse......................................................37

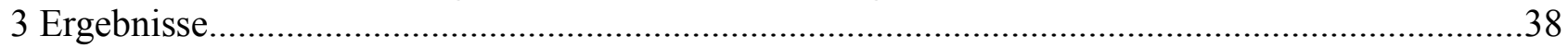

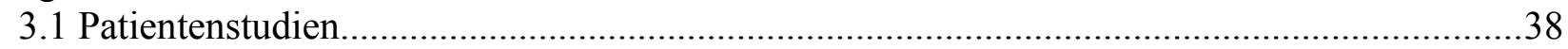

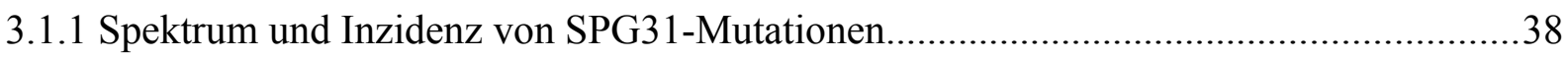

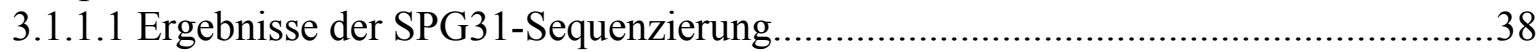

3.1.1.2 Detektion von Deletionen/ Duplikationen mittels „Multiplex Ligation-dependent

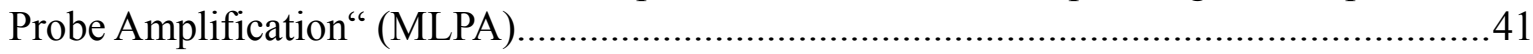

3.1.2 Charakterisierung der betroffenen Familien...........................................................42

3.1.2.1 Charakterisierung des Indexpatienten 30213 und seiner Familie.........................42

3.1.2.2 Charakterisierung der Indexpatientin 28103 und ihrer Familie............................44

3.2 Expressionsanalyse von REEP1 in verschiedenen humanen Geweben.................................45

3.2.1 Mundschleimhaut und Zellen der Speicheldrüsen und -ausführungsgänge.....................46

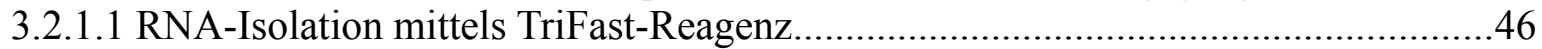

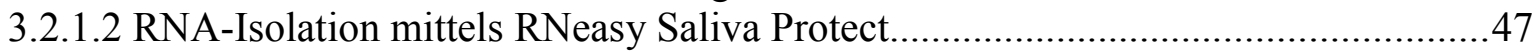

3.2.2 RNA aus Urothelzellen und Epithelien der ableitenden Harnwege aus Spontanurin......48

3.2.3 RNA-Isolation aus Haarwurzeln........................................................................................49

3.3 Effekt von Mutationen im Bereich von miRNA-Bindestellen...............................................52

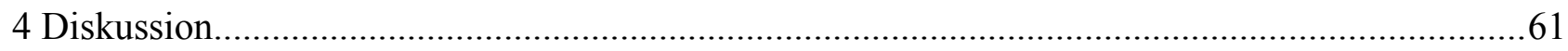

4.1 Molekulargenetik der Hereditären Spastischen Paraplegie Typ 31......................................6 61

4.2 Klinische Merkmale der Hereditären Spastischen Paraplegie Typ 31.................................64

4.3 Manifestationsalter der Hereditären Spastischen Paraplegie Typ 31....................................66

4.4 Epidemiologie der Hereditären Spastischen Paraplegie Typ 31 ........................................66

4.5 Expressionsanalyse von REEP1 in verschiedenen humanen Geweben..............................67

4.5.1 Mundschleimhaut und Zellen der Speicheldrüsen und -ausführungsgänge....................67

4.5.2 Urothelzellen und Epithelien der ableitenden Harnwege aus Spontanurin......................69

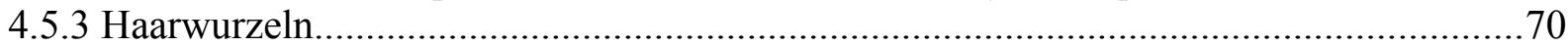

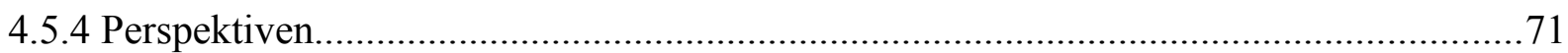

4.6 Rolle von Mutationen im Bereich von miRNA-Bindestellen in der Pathogenese der

Hereditären Spastischen Paraplegie 31 .............................................................................. 72

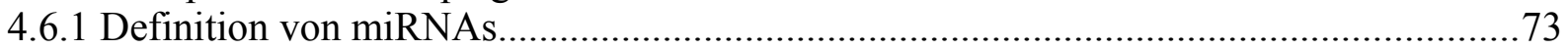

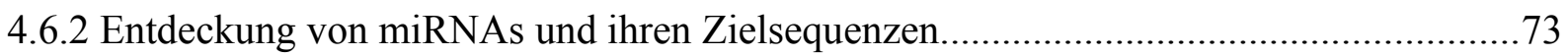

4.6.3 Biogenese und Funktion von miRNAs...................................................................... 74

4.6.4 miRNAs und ihre Rolle bei der Pathogenese humaner Erkrankungen...........................75 
4.6.5 Rolle von miRNAs bei der Hereditären Spastischen Paraplegie 31............................76

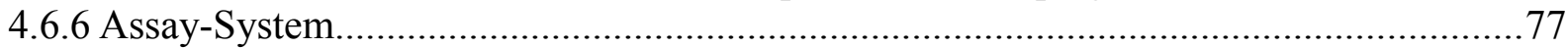

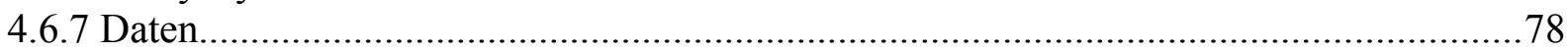

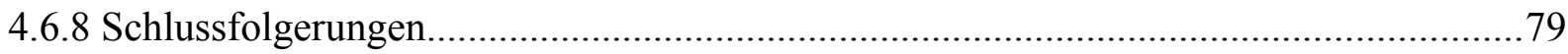

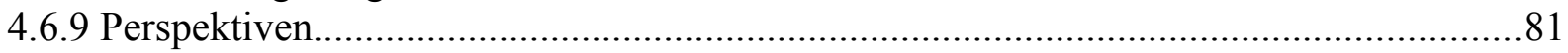

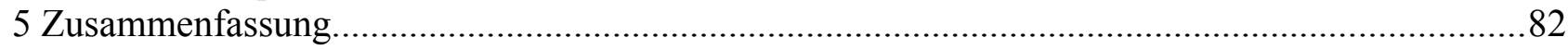

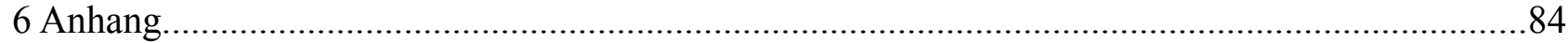

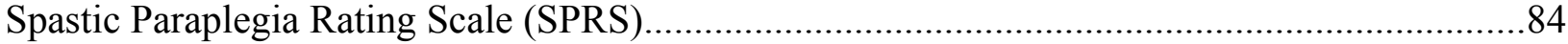

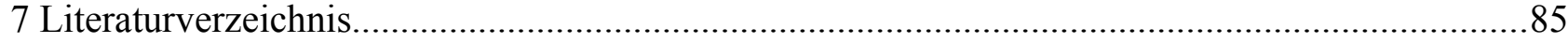

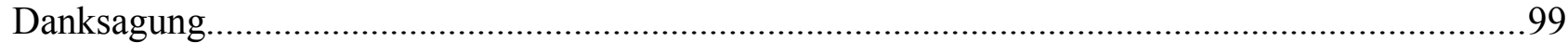




\section{Abkürzungsverzeichnis}

\begin{tabular}{|c|c|}
\hline Abb. & Abbildung(en) \\
\hline ADHSP & autosomal dominante Hereditäre Spastische Paraplegie \\
\hline APP & Alzheimer-Precursor-Protein \\
\hline ARHSP & autosomal rezessive Hereditäre Spastische Paraplegie \\
\hline ATP & Adenosintriphosphat \\
\hline BLAST & Basic local alignment search tool \\
\hline $\mathrm{bp}$ & Basenpaare \\
\hline bzw. & beziehungsweise \\
\hline $\mathrm{c}$ & Konzentration \\
\hline${ }^{\circ} \mathrm{C}$ & Grad Celsius \\
\hline ca. & zirka \\
\hline cDNA & komplementäre DNA \\
\hline del & Deletion \\
\hline DMEM & Dulbeccos Modifiziertes Eagle-Medium \\
\hline DNA & Desoxyribonukleinsäure \\
\hline DNase & Desoxyribonuklease \\
\hline dNTPs & Desoxyribonukleosidtriphosphate \\
\hline DP1 & Dodeca-Satellite-binding Protein 1 \\
\hline DTT & Dithiothreitol \\
\hline E. coli & Escherichia coli \\
\hline EDTA & Ethylendiamintetraessigsäure \\
\hline ER & Endoplasmatisches Reticulum \\
\hline
\end{tabular}




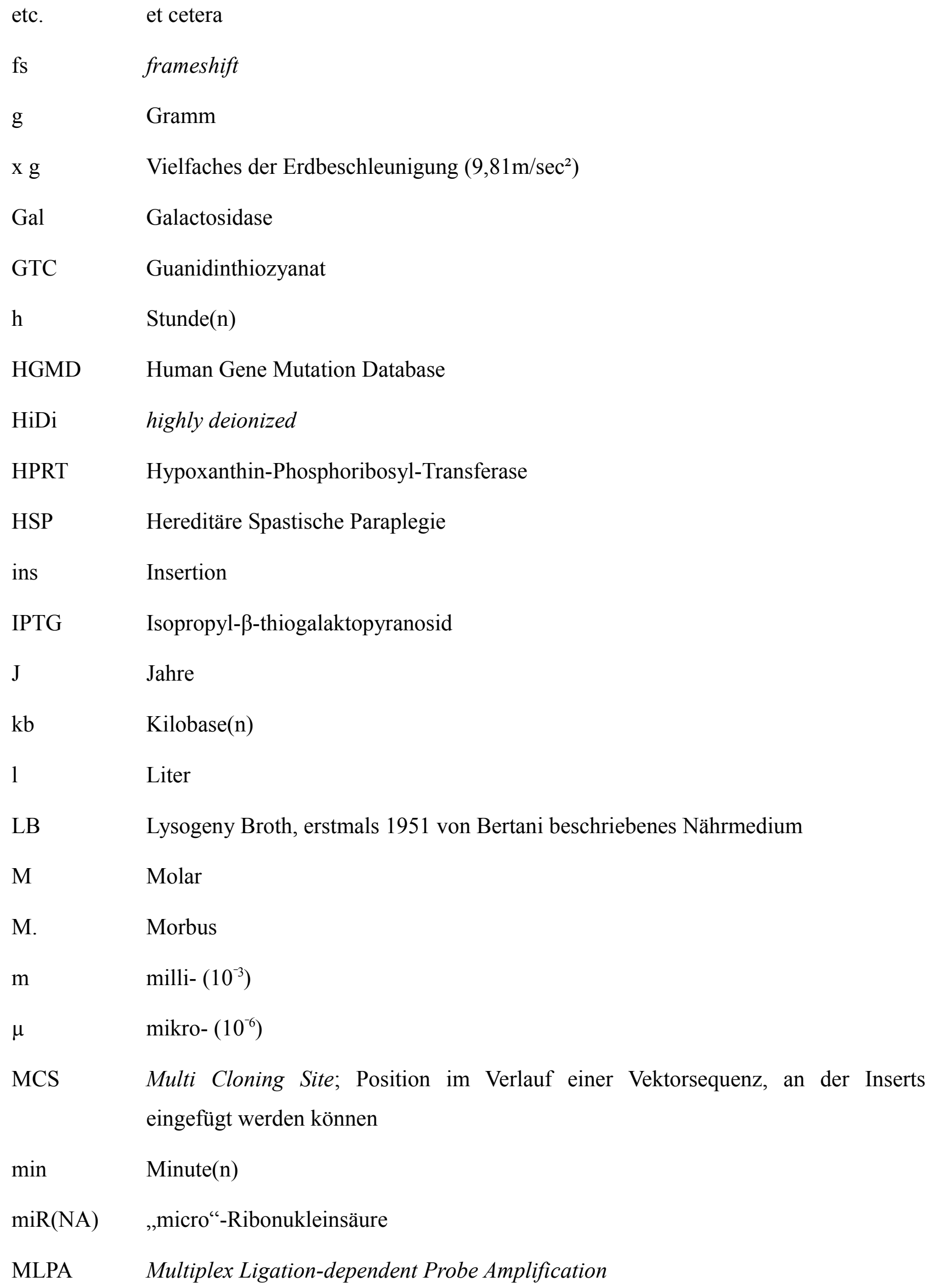




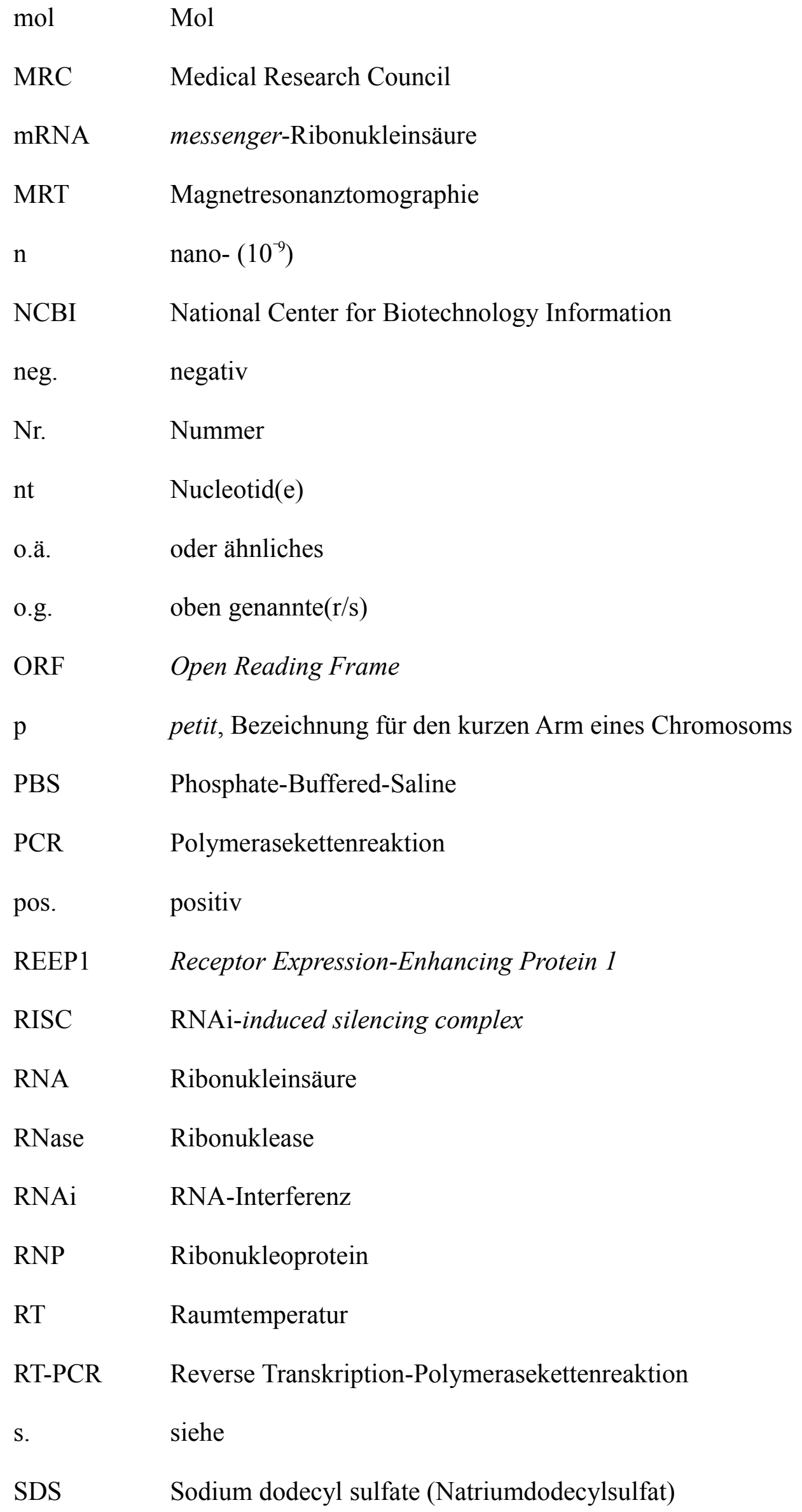


$\sec$

Sekunde(n)

SFSP Strümpells familiäre spastische Paraplegie

sog. $\quad$ so genannte $(-r /-s)$

SPG spastische Paraplegie

s.u. siehe unten

Tab. Tabelle(n)

Taq Thermophilus aquaticus

TBE Tris-Borat-Ethylendiamintetraessigsäure

TE Tris-Ethylendiamintetraessigsäure

Tris Tris-Hydroxymethyl-Aminomethan

U unit

u.a. unter anderem

UTR untranslated region

UV Ultraviolett

VAS visuelle Analogskala

vgl. vergleiche

vol. Volumen

v/v Volumen pro Volumen

WT Wildtyp

w/v Gewicht pro Volumen

X Stopp-Codon (bei der Angabe genetischer Veränderungen)

X-Gal 5-Bromo-4-Chloro-3-Indolyl- $\beta$-D-Galaktopyranosid

z.B. $\quad$ zum Beispiel 


\section{Nukleinsäure-Symbole}
A Adenin
C Cytosin
G Guanin
T Thymin
U Uracil

\section{Aminosäure-Symbole}

$\begin{array}{llllll}\text { A } & \text { Ala } & \text { Alanin } & \text { M } & \text { Met } & \text { Methionin } \\ \text { C } & \text { Cys } & \text { Cystein } & \text { N } & \text { Asn } & \text { Asparagin } \\ \text { D } & \text { Asp } & \text { Asparaginsäure } & \text { P } & \text { Pro } & \text { Prolin } \\ \text { E } & \text { Glu } & \text { Glutaminsäure } & \text { Q } & \text { Gln } & \text { Glutamin } \\ \text { F } & \text { Phe } & \text { Phenylalanin } & \text { R } & \text { Arg } & \text { Arginin } \\ \text { G } & \text { Gly } & \text { Glycin } & \text { S } & \text { Ser } & \text { Serin } \\ \text { H } & \text { His } & \text { Histidin } & \text { T } & \text { Thr } & \text { Threonin } \\ \text { I } & \text { Ile } & \text { Isoleucin } & \text { V } & \text { Val } & \text { Valin } \\ \text { K } & \text { Lys } & \text { Lysin } & \text { W } & \text { Trp } & \text { Tryptophan } \\ \text { L } & \text { Leu } & \text { Leucin } & \text { Y } & \text { Tyr } & \text { Tyrosin }\end{array}$




\section{Abbildungsverzeichnis}

Abb. 1: Histopathologische Präparate des Rückenmarks dreier verstorbener SPG-Patienten (A-C),

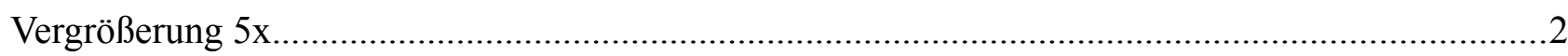

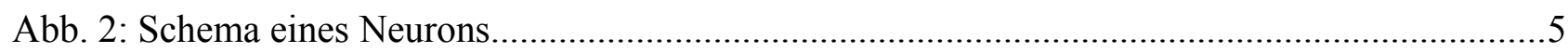

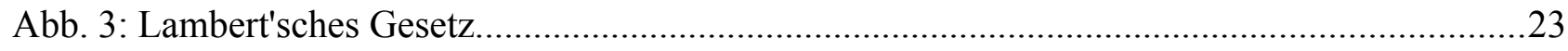

Abb. 4: Auszug aus der Sequenz des SPG31-Exons 7 des Indexpatienten 30213.........................39

Abb. 5: pGEM-T Easy-Vektorkarte

Abb. 6: Ausschnitt der Sequenzen des in pGEM-T Easy klonierten Exons 7................................40

Abb. 7: Auszug aus der Sequenz des SPG31-Exons 4 von 28103 ............................................. 41

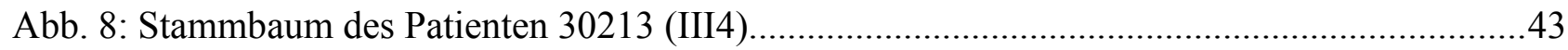

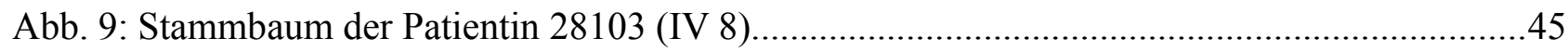

Abb. 10: cDNA-PCR-Produkte des zweiten Versuchs. RNA wurde aus Mundschleimhaut und Speichel isoliert, in cDNA umgeschrieben, mit den entspechenden Primern (HPRT bzw. SPG31) amplifiziert und dann auf ein 1,8\%-Agarosegel aufgetragen.

Abb. 11: cDNA-PCR-Produkte des vierten Versuchs. RNA wurde aus Mundschleimhaut und Speichel isoliert, in cDNA umgeschrieben, mit den entspechenden Primern (HPRT bzw. SPG31) amplifiziert und dann auf ein 1,8\%-Agarosegel aufgetragen.

Abb. 12: cDNA-PCR-Produkte des dritten Versuchs. RNA wurde aus Urothelzellen isoliert, in cDNA umgeschrieben, mit den entspechenden Primern (HPRT bzw. SPG31) amplifiziert und dann auf ein 1,8\%-Agarosegel aufgetragen

Abb. 13: cDNA-PCR-Produkte aus dem ersten Versuch, RNA aus Haarwurzeln zu isolieren, aufgetragen auf ein 1,8\%-Agarosegel.

Abb. 14: cDNA-PCR-Produkte aus dem vierten Versuch, RNA aus Haarwurzeln zu isolieren, aufgetragen auf ein 1,8\%-Agarosegel.

Abb. 15: cDNA-PCR-Produkte dreier unabhängiger Versuche, RNA aus Haarwurzeln zu isolieren, aufgetragen auf ein 1,8\%-Agarosegel.

Abb. 16: Bindung der miR-691 an Wildtyp-3'UTR und mutierte 3'UTR......................................53

Abb. 17: Schema der für den Luciferase-Assay eingesetzten mutierten 3'UTR 
Abb. 18: Schema des Vektors pMIR-REPORT miRNA Expression Reporter für den LuciferaseAssay.

Abb. 19: Reaktionsgleichung der vom Enzym Luciferase katalysierten Reaktion. .54

Abb. 20: Schema des pMIR REPORT Beta-Gal Control-Vektors. .55

Abb. 21: Graphische Darstellung der gegen den Mittelwert der Probe 1 normalisierten Messergebnisse der ersten Transfektion. 56

Abb. 22: Graphische Darstellung der gegen den Mittelwert der Probe 1 normalisierten Messergebnisse der zweiten Transfektion. .57

Abb. 23: Graphische Darstellung der gegen den Mittelwert der Probe 1 normalisierten Messergebnisse der dritten Transfektion. .58

Abb. 24: Graphische Darstellung der gegen den Mittelwert der Probe 1 normalisierten Messergebnisse der vierten Transfektion. .59

Abb. 25: Graphische Darstellung der gegen den Mittelwert der Probe 1 normalisierten Messergebnisse der fünften Transfektion.

Abb. 26: Graphische Darstellung der gegen den Mittelwert der Probe 1 normalisierten Messergebnisse der sechsten Transfektion. 60

Abb. 27: Übersicht über die bislang beschriebenen Mutationen in REEP1 61

Abb. 28: Mögliche Effekte einer Splice-Site-Mutation. .72

Abb. 29: MicroRNA-Biogenese .75

Abb. 30: Hochkonservierte Bindungsstelle an der 3'-Sequenz von REEP1 am Beispiel der miRNA691 bei verschiedenen Spezies. .77

Abb. 31: Schema des Vorgehens beim Luciferase-Assay. .78 


\section{Tabellenverzeichnis}

Tab. 1: Bislang bekannte HSP-Formen...................................................................................

Tab. 2: Strenge Parameter für die Primerauswahl mit Primer3 ......................................................24

Tab. 3: Weniger strenge Parameter für die Primerauswahl mit Primer3........................................24

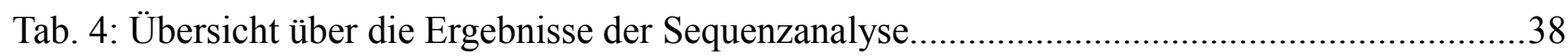

Tab. 5: Übersicht über die gefundenen Mutationen............................................................4

Tab. 6: Übersicht über die Ergebnisse der MLPA-Analyse......................................................42

Tab. 7: Übersicht über alle durchgeführten Versuche, RNA aus Haarwurzeln zu isolieren und daran

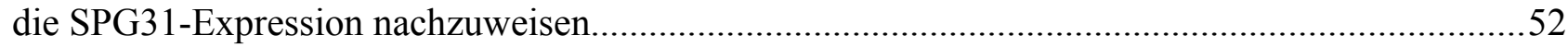

Tab. 8: Übersicht über die bisher beschriebenen Splice-Site-Mutationen. (HGMD, http://www.biobase-international.com, 22.01.2013)..................................................................62

Tab. 9: Übersicht über die bislang beschriebenen Missense und Nonsense-Mutationen in REEP1 (HGMD, http://www.biobase-international.com, 22.01.2013)

Tab. 10: Übersicht über die bisher beschriebenen Mutationen in der regualtorisch wichtigen 3' untranslatierten Region des REEP1-Gens. (HGMD, http://www.biobase-international.com, 22.01.2013) 64

Tab. 11: Übersicht über die bisher beschriebenen großen genomischen Rearrangements. HGMD, http://www.biobase-international.com, 22.01.2013 ...................................................................64

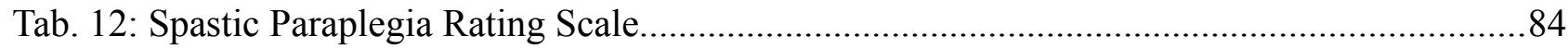




\section{Einleitung}

\subsection{Die Hereditären Spastischen Paraplegien}

Der Begriff der Hereditären Spastischen Paraplegien (HSP) umschreibt eine Gruppe klinisch und genetisch heterogener Krankheitsbilder. Die Erstbeschreibung dieser Gruppe von Erkrankungen erfolgte 1880 durch den Neurologen Adolf von Strümpell: Er beobachtete zwei Brüder mit einer progredienten familiären Gangstörung. Auch Lorrain beschrieb 1898 drei Patienten mit symmetrischer Spastik der Beine. In seinem Kollektiv befand sich aber erstmals ein Patient mit kompliziertem Phänotyp: Es fanden sich zusätzlich zur Gangstörung weitere neurologische Defizite. Synonyme für HSP sind Strümpell-Lorrain'sche Erkrankung oder Strümpells Familiäre Spastische Paraplegie (SFSP) (Behan und Maia 1974).

Das Erkrankungsbild wird bestimmt durch eine zunehmende spastische Tonuserhöhung und Schwäche der Muskulatur vor allem der unteren Extremitäten. Dies führt im Verlauf zu einem charakteristischen spastisch-ataktischen Gangbild und später häufig zur RollstuhlAbhängigkeit. Gesteigerte Muskeleigenreflexe zeigen sich sowohl im Bereich der unteren als auch der oberen Extremitäten. Des Weiteren sind Pyramidenbahnzeichen, etwa ein positiver Babinski-Reflex, charakteristisch. Gelegentlich haben die Patienten ein herabgesetztes Vibrationsempfinden im Bereich der distalen unteren Extremitäten und Blasenentleerungsstörungen (Urge-Inkontinenz) (McDermott et al. 2000, Sauter et al. 2002, Finsterer 2003).

Klinisch erfolgt eine Unterteilung in komplizierte und unkomplizierte Phänotypen. Patienten, die an einer komplizierten HSP leiden, zeigen zusätzlich zu den oben beschriebenen Symptomen weitere neurologische Auffälligkeiten, wie zerebrale Krampfanfälle, Amyotrophie, Ataxie, mentale Retardierung, Demenz, Sehschwäche und/ oder Taubheit (Harding 1983).

Die Diagnosestellung „Spastische Paraplegie“ erfolgt nach ausführlicher klinischneurologischer Untersuchung vor allem als Ausschlussdiagnose. Differentialdiagnostisch muss u.a. an spastische Zerebralparesen, Metachromatische Leukodystrophien oder Adrenoleukodystrophien, Amyotrophe Lateralsklerose, Vitamin-Mangelzustände und zerebrale- oder spinale Raumforderungen gedacht werden (Finsterer 2003, De Bot et al. 2010). 
Aus Autopsien ergab sich als Ursache für die Entwicklung einer spastischen Paraplegie ein nach distal zunehmender Verlust von Motorneuronen im Bereich der Pyramidenbahn (Tractus corticospinalis). Es fand sich außerdem eine Degeneration der Hinterstrangbahnen (Behan und Maia 1974). Dies veranschaulichen auch die histologischen Präparate in Abbildung 1.

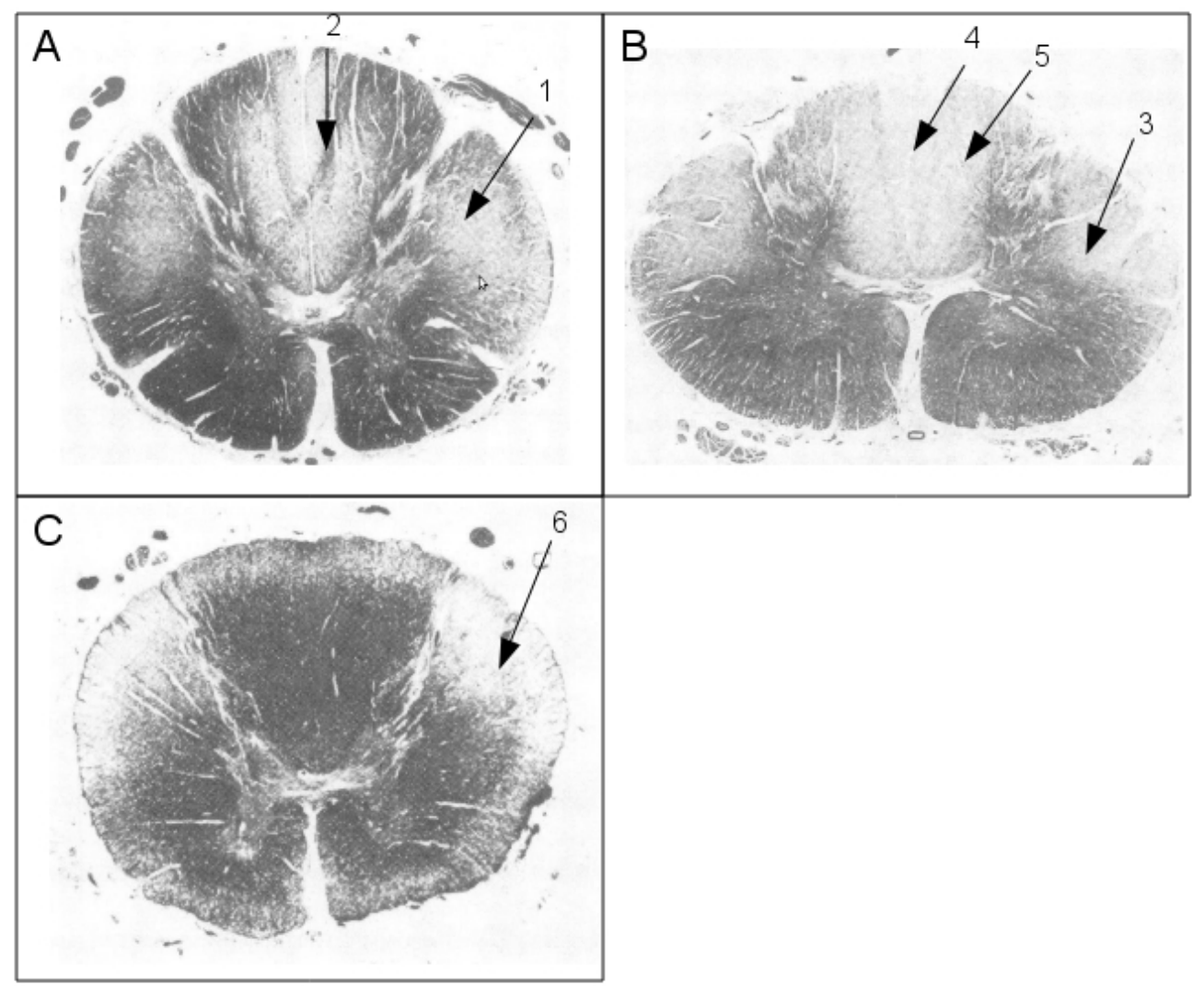

Abb. 1: Histopathologische Präparate des Rückenmarks dreier verstorbener SPG-Patienten (A-C), Vergrößerung $5 x$.

A: Querschnitt auf Höhe Th1. Deutliche Blässe des Tractus corticospinalis lateralis (1), schwere Degeneration des Fasciculus gracilis (2). B: Querschnitt auf Höhe C6. Moderate Beteiligung des lateralen Tractus corticospinalis (3), schwere Beteiligung der Fasciculi gracilis (4) et cuneatus (5). C: Querschnitt im unteren BWS-Bereich. Stark abgeblasstes Myelin im Bereich des Tractus corticospinalis lateralis (6) (modifiziert nach Behan und Maia 1974, Seite 12).

Magnetresonanztomographisch können eine Corpus callosum-Atrophie, eine periventrikuläre Leukomalazie oder eine milde (Klein-) Hirnatrophie beobachtet werden (Somasundaram et al. 2007, Scuderi et al. 2008, Hourani et al. 2009, Duning et al. 2010, Guidubaldi et al. 2011, Stromillo et al. 2011). Im spinalen MRT findet sich häufig eine thorakal betonte Atrophie des Rückenmarks (Hedera et al. 2005, Liu et al. 2009, Monrad et al. 2011). Bei vielen Patienten liegen jedoch unauffällige MRT-Befunde vor. 
Zur Prävalenz in Deutschland gibt es bislang keine Daten. Verschiedene Studien in Europa zeigen regional stark schwankende Prävalenzen: Erichsen et al. (2009) fanden 7,4 Betroffene pro 100000 Einwohner in Norwegen, in Portugal lag die Prävalenz bei zwei Erkrankten pro 100000 Einwohner (Silva et al. 1997). Eine Studie in Irland zeigt für autosomal dominante spastische Paraplegien eine Prävalenz von 1,27 Patienten pro 100000 Einwohner (McMonagle et al. 2002).

Eine kausale Therapie der Erkrankung steht derzeit noch nicht zur Verfügung. Symptomatische Therapieansätze umfassen Physiotherapie, Orthesen- und Hilfsmittelversorgung sowie eine Reduktion der Spastik z.B. durch Baclofen, Dantrolen oder Tetrazepam. Auch Botulinumtoxin-Injektionen oder chirurgische Korrekturen, z.B. bei schweren Fußfehlstellungen, können in Betracht gezogen werden (Harding 1993, Sauter et al. 2002, Züchner 2007).

\subsection{Genetik der Hereditären Spastischen Paraplegien}

Mittlerweile sind 48 verschiedene Genloci bekannt und mehr als 20 Gene identifiziert, die bei Mutationen zum klinischen Bild einer spastischen Paraplegie führen. Unter diesen gibt es autosomal dominant, autosomal rezessiv und X-chromosomal rezessiv vererbte Formen. Die größte Gruppe bilden mit 70-80\% die autosomal dominanten Formen (ADHSP), darunter finden sich in bis zu 40\% der Fälle Mutationen in SPG4 (SPAST), ca. 10\% der Betroffenen zeigen Mutationen in SPG3A (ATL1) und bei bis zu 8,2\% der Patienten sind SPG31(REEP1)Mutationen zu finden. Die häufigsten rezessiven Formen (ARHSP) sind SPG7 und SPG11. Xchromosomale spastische Paraplegien sind insgesamt sehr selten. Es finden sich Mutationen in SPG1 (L1CAM) und SPG2 (PLP1) (McDermott et al. 2006, Depienne et al. 2007, Beetz et al. 2008, Salinas et al. 2008). Die Tabelle 1 zeigt eine Übersicht über die bekannten Genloci. 
Tab. 1: Bislang bekannte HSP-Formen.

Bei vielen HSP-Typen wurde der Name des Gens durch das HUGO Gene Nomenclature Committee ersetzt (vgl. http://www.genenames.org) (Tabelle aktualisiert nach Salinas et al. 2008.

http://www.ncbi.nlm.nih.gov/gene, Stand 7/2012).

\begin{tabular}{|c|c|c|c|c|}
\hline HSP-Typ & Gen & Vererbungsmodus & Locus & Protein \\
\hline SPG1 & L1CAM & X-chromosomal & $\mathrm{Xq} 28$ & L1 Zell Adhäsions Molekül \\
\hline SPG2 & PLP1 & X-chromosomal & Xq21 & Proteolipoprotein \\
\hline SPG3A & ATL1 & autosomal dominant & $14 q 12-q 21$ & Atlastin \\
\hline SPG4 & SPAST & autosomal dominant & $2 p 22$ & Spastin \\
\hline SPG5A & CYP7B1 & autosomal rezessiv & $8 q 21.3$ & Cytochrom P450-7B1 \\
\hline SPG6 & NIPA1 & autosomal dominant & $15 q 11.2-q 12$ & Non-imprinted in Prada-Willi/ Angelman syndrome region protein 1 \\
\hline SPG7 & SPG7 & autosomal rezessiv & $16 q 24.3$ & Paraplegin \\
\hline SPG8 & KIAA0196 & autosomal dominant & $8 q 24$ & Strümpellin \\
\hline SPG9 & unbekannt & autosomal dominant & $10 q 23.3-24.2$ & unbekannt \\
\hline SPG10 & KIF5A & autosomal dominant & $12 q 13$ & Kinesin Familienmitglied 5A \\
\hline SPG11 & SPG11 & autosomal rezessiv & $15 q 11.2-q 12$ & Spatacsin \\
\hline SPG12 & unbekannt & autosomal dominant & $19 q 13$ & unbekannt \\
\hline SPG13 & HSPD1 & autosomal dominant & $2 q 24-q 34$ & Hitze-Schock-Protein 60 \\
\hline SPG14 & SPG14 & autosomal rezessiv & $3 q 27-q 28$ & unbekannt \\
\hline SPG15 & ZFYVE26 & autosomal rezessiv & $14 q 22-q 24$ & Spastizin \\
\hline SPG16 & unbekannt & X-chromosomal & Xq11.2 & unbekannt \\
\hline SPG17 & BSCL2 & autosomal dominant & $11 q 12-q 14$ & Seipin \\
\hline SPG18 & unbekannt & autosomal dominant & 8p12-p11.21 & unbekannt \\
\hline SPG19 & unbekannt & autosomal dominant & $9 q 33-q 34$ & unbekannt \\
\hline SPG20 & SPG20 & autosomal rezessiv & $13 q 12.3$ & Spartin \\
\hline SPG21 & SPG21 & autosomal rezessiv & $15 q 21-q 22$ & Maspardin \\
\hline SPG22 & $S L C 16 A 2$ & X-chromosomal & & \\
\hline SPG23 & unbekannt & autosomal rezessiv & $1 q 24-q 32$ & unbekannt \\
\hline SPG24 & unbekannt & autosomal rezessiv & $13 q 14$ & unbekannt \\
\hline SPG25 & unbekannt & autosomal rezessiv & $6 q 23-q 24.1$ & unbekannt \\
\hline SPG26 & unbekannt & autosomal rezessiv & $12 p 11.1-q 14$ & unbekannt \\
\hline SPG27 & unbekannt & autosomal rezessiv & $10 q 22.1-q 24.1$ & unbekannt \\
\hline SPG28 & unbekannt & autosomal rezessiv & $14 q 21.3-q 22.3$ & unbekannt \\
\hline SPG29 & unbekannt & autosomal dominant & $1 \mathrm{p} 31-\mathrm{p} 21$ & unbekannt \\
\hline SPG30 & KIF1A & autosomal rezessiv & $2 q 37.3$ & Kinesin-ähnliches Protein KIF1A \\
\hline SPG31 & REEP1 & autosomal dominant & $2 \mathrm{p} 12$ & Receptor Expression-Enhancing Protein 1 \\
\hline SPG32 & unbekannt & autosomal rezessiv & $14 q 14-q 21$ & unbekannt \\
\hline SPG33 & ZFYVE27 & autosomal dominant & $10 q 24.2$ & Zink-Finger FYE Domäne-enthaltendes Protein 27 \\
\hline SPG34 & unbekannt & X-chromosomal & Xq24-q25 & unbekannt \\
\hline SPG35 & $\mathrm{FA} 2 \mathrm{H}$ & autosomal rezessiv & $16 q 21-q 23$ & Fettsäure 2-Hydroxylase \\
\hline SPG36 & unbekannt & autosomal dominant & $12 q 23-q 24$ & unbekannt \\
\hline SPG37 & unbekannt & autosomal dominant & $8 p 21.1-q 13.3$ & unbekannt \\
\hline SPG38 & unbekannt & autosomal dominant & $4 p 16-p 15$ & unbekannt \\
\hline SPG39 & PNPLA6 & autosomal rezessiv & $19 \mathrm{p} 13.2$ & Neuropathie Ziel Esterase \\
\hline SPG41 & unbekannt & autosomal rezessiv & $11 \mathrm{p} 14.1-\mathrm{p} 11.2$ & unbekannt \\
\hline SPG42 & SLC33A1 & autosomal dominant & $3 q 25.31$ & Acetyl-Coenzym A Transporter 1 \\
\hline SPG43 & unbekannt & autosomal rezessiv & 19p13.11-q12 & unbekannt \\
\hline SPG44 & GJC2 & autosomal rezessiv & $1 q 42.13$ & Gap junction Protein \\
\hline SPG45 & unbekannt & autosomal rezessiv & 10q24.3-q25.1 & unbekannt \\
\hline SPG46 & unbekannt & autosomal rezessiv & $9 p 21.2-q 21.12$ & unbekannt \\
\hline SPG47 & AP4B1 & autosomal rezessiv & 1p13.2-1p12 & Adaptor-related Protein-Komplex 4, $\beta 1$-Untereinheit \\
\hline SPG48 & KIAA0415 & autosomal rezessiv & $7 p 22.2$ & unbekannt \\
\hline SPG50 & AP4M1 & autosomal rezessiv & 7q22.1 & Adaptor-related Protein-Komplex 4, mu1-Untereinheit \\
\hline SPG51 & AP4E1 & autosomal rezessiv & $15 q 21.2$ & Adaptor-related Protein-Komplex 4, ع1-Untereinheit \\
\hline SPG52 & AP4S1 & autosomal rezessiv & $14 q 12-q 21$ & Adaptor-related Protein-Komplex 4, o1-Untereinheit \\
\hline SPG53 & VPS37A & autosomal rezessiv & $8 p 22$ & Vascuolar Protein Sorting 37 Homolog \\
\hline
\end{tabular}




\subsection{Pathomechanismen der Hereditären Spastischen Paraplegien}

Auf zellulärer Ebene gibt es verschiedene Erklärungsansätze für die axonale Degeneration der langen Motorneurone. Bei der häufigsten autosomal dominanten HSP, nämlich bei der SPG4, führen Mutationen im SPAST-Gen zu einer mangelhaften Microtubulus-Interaktion und somit zu einer Störung des axonalen Transports. Ein ineffektiver intrazellulärer Membrantransport, wie z.B. bei Mutationen im SPG3A-Gen zwischen Endoplasmatischem Reticulum und GolgiApparat, stellt einen weiteren Pathomechanismus dar. Auch eine abnorme Mitochondrienfunktion und dadurch bedingte Defizite im Energiehaushalt (SPG7) spielen eine Rolle bei der Entwicklung spastischer Paraplegien (Salinas et al. 2008). Die Abbildung 2 zeigt eine Übersicht über die Zellorganellen, die bei den verschiedenen HSP-Formen betroffenen sind.

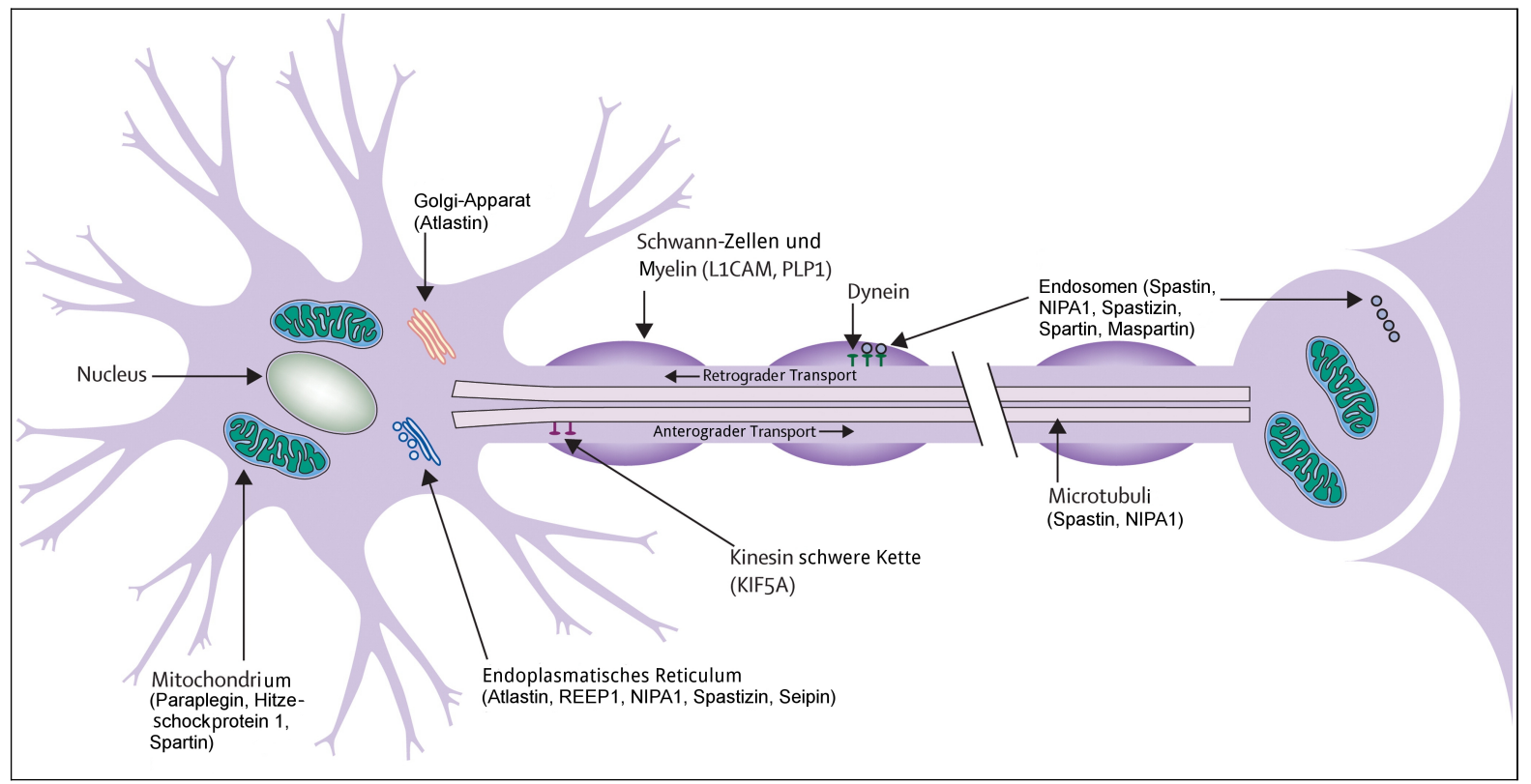

Abb. 2: Schema eines Neurons.

Gezeigt wird die Lokalisation der verschiedenen HSP-Proteine, die eine Rolle bei der Pathogenese spastischer Paraplegien spielen (modifiziert nach Salinas et al. 2008, Seite 8).

\subsection{Die Hereditäre Spastische Paraplegie Typ 31}

Die vorliegende Arbeit beschäftigt sich mit der Hereditären Spastischen Paraplegie Typ 31. Mutationen im 2006 entdeckten REEPI-Gen stellen die dritthäufigste Ursache für autosomal dominante Hereditäre Spastische Paraplegien dar. 
Das Gen hat eine Länge von $127 \mathrm{~kb}$ und ist auf dem kurzen Arm von Chromosom 2, genauer in 2 p12, lokalisiert. Es besteht aus sieben Exons und enthält hochkonservierte miRNABindestellen im Bereich der 3'UTR. REEP1 codiert für das Receptor Expression-Enhancing Protein 1, das vermutlich zwei Transmembrandomänen enthält und zunächst für ein mitochondriales Protein mit Chaperon-ähnlicher Funktion gehalten wurde (Züchner et al. 2006). Es zeigte sich jedoch, dass REEP1 im Bereich des tubulären Endoplasmatischen Reticulums (ER) lokalisiert ist und strukturelle Ähnlichkeit zu Proteinen der DP1/ Yop1pFamilie aufweist. Diese sind an der Bildung des tubulären Endoplasmatischen Retikulums (ER) sowie der ER-Interaktion mit Mikrotubuli beteiligt. REEP1 interagiert über eine hydrophobe Haarnadeldomäne mit den HSP-Proteinen Atlastin-1 (SPG3A) und Spastin (SPG4), welche ebenfalls eine Rolle bei der Bildung von ER-Tubuli spielen (Salinas et al. 2007, Hu et al. 2009, Park et al. 2010).

\subsection{Ziele dieser Arbeit}

Im Institut für Humangenetik der Universitätsmedizin Göttingen werden molekulargenetische Analysen auf Mutationen im SPG31-Gen bei Familien mit Verdacht auf ADHSP durchgeführt. Einschlusskriterien für die Untersuchung sind neben dem autosomal dominanten Erbgang unauffällige Befunde der molekulargenetischen Analyse der SPG4 und $S P G 3 A$-Gene. Ziele der vorliegenden Dissertation sind:

- Die Prävalenz von SPG31-Mutationen im Patientenkollektiv des Instituts für Humangenetik Göttingen herauszufinden.

- Die betroffenen Familien zu charakterisieren und mit den klinischen Daten der aktuellen Literatur zu vergleichen.

- Der Versuch, einen nicht invasiven Assay zur Untersuchung von Splice-SiteMutationen in SPG31 zu etablieren.

- Mutationen, die miRNA-Bindestellen betreffen, mithilfe eines Luciferase-Assays zu untersuchen. 


\section{Material und Methoden}

\subsection{Material}

\subsubsection{Chemikalien und Reagenzien}

Alle nicht aufgeführten Chemikalien wurden von den Firmen Sigma (Deisenhofen) und Carl Roth GmbH \& Co (Karlsruhe) bezogen.

\section{Substanz}

$1 \mathrm{~kb}-$ Leiter

Agarose

Ampuwa

Borsäure

Chloroform

Dithiothreitol (DTT)

DMEM

dNTPs (100 mM)

DPBS

Ethylendiamin-tetraessigsäure (EDTA)

Ficoll 400

FKS

Formaldehyd

Glycerin

Glykogen

Hefeextrakt

HiDi Formamid

Isopropyl- $\beta$-D-thiogalactopyranosid (IPTG)

Isopropanol

LIZ Size Standard

Natriumdodecylsulfat (SDS)

Natronlauge $(\mathrm{NaOH})$

Peq GOLD TriFast

Puregene Cell Lysis Solution

\section{Hersteller}

Invitrogen, Karlsruhe

Bio Budget Technologies GmbH, Krefeld

Fresenius Kabi GmbH, Bad Homburg

ICN Biomedicals, Eschwege

Merck, Darmstadt

Biomol, Hamburg

PAN Biotech, Aidenbach

Invitrogen, Karlsruhe

PAN Biotech, Aidenbach

ICN Biomedicals, Eschwege

Applichem, Darmstadt

PAN Biotech, Aidenbach

Merck, Darmstadt

Merck, Darmstadt

Carl Roth GmbH \& Co., Karlsruhe

Carl Roth GmbH \& Co., Karlsruhe

Applied Biosystems, Darmstadt

Biomol, Hamburg

Merck, Darmstadt

Applied Biosystems, Darmstadt

Serva, Heidelberg

Merck, Darmstadt

PeqLab Biotechnologie GmbH, Erlangen

Qiagen, Hilden 


\section{Substanz \\ RNase A \\ RNase away \\ Trypsin \\ X-Gal}

\subsubsection{Enzyme}

\section{Enzym}

Immolase DNA Polymerase

Platinum Taq DNA Polymerase

Restriktionsenzyme

Superscript II Reverse Transkriptase

T4 DNA Ligase

TaKaRa LA Taq Polymerase

\section{Hersteller}

Qiagen, Hilden

Applichem, Darmstadt

TrypLE Express, Invitrogen, Karlsruhe

Biomol, Hamburg

\subsubsection{Antibiotika}

\author{
Hersteller \\ Bioline, Luckenwalde \\ Invitrogen, Karlsruhe \\ Biolabs, Beverly (USA) \\ Invitrogen, Karlsruhe \\ Invitrogen, Karlsruhe \\ Promega, Mannheim \\ Takara Bio Inc., Shiga (Japan)
}

$\begin{array}{lll}\text { Antibiotikum (Konzentration) } & \text { Verwendete Verdünnung } & \text { Hersteller } \\ \text { Ampicillin }(100 \mathrm{mg} / \mathrm{ml}) & 100 \mu \mathrm{g} / \mathrm{ml} & \text { Sigma, Deisenhofen } \\ \text { Penicillin }(10 \mathrm{mg} / \mathrm{ml}) & 100 \mu \mathrm{g} / \mathrm{ml} & \text { PAN Biotech, Aidenbach } \\ \text { Streptomycin }(10000 \mathrm{U} / \mathrm{ml}) & 100 \mathrm{U} / \mathrm{ml} & \text { PAN Biotech, Aidenbach }\end{array}$

\subsubsection{Gebrauchsfertige Reaktionssysteme}

Kit

Attractene Transfection Reagent

DNeasy Blood \& Tissue Kit

DYEnamic ET Dye Terminator Kit

\section{Hersteller}

Qiagen, Hilden

Qiagen, Hilden

Amersham Pharmacia Biotech, Freiburg 


\section{Kit}

EndoFree Plasmid Maxi Kit

- Puffer P1

- Puffer P2

- Puffer P3

- Puffer ER

- Puffer QBT

- Puffer QC

- Puffer QN

Luciferase Assay System

- Cell Culture Lysis Reagent 5x

- Luciferase Assay Substrate

- Luciferase Assay Puffer

P213 MLPA Kit

- Salsa Pro Mix

- MLPA Puffer

- Ligase-Puffer A

- Ligase-Puffer B

- Ligase

- Salsa PCR-Puffer

- Enzym

- Polymerase

QuikChange Site-directed Mutagenesis Kit

- PfuTurbo DNA Polymerase $(2.5 \mathrm{U} / \mu \mathrm{l})$

- $10 \times$ Reaction Buffer

- DpnI Restriction Enzyme $(10 \mathrm{U} / \mu \mathrm{l})$

- Oligonucleotide Control Primer 1

- Oligonucleotide Control Primer 2

- WhitescriptTM 4.5-kb Control Plasmid ( $5 \mathrm{ng} / \mu \mathrm{l})$

- dNTP mix

- XL1-Blue Supercompetent Cells

- pUC18 Control Plasmid (0.1 ng/ $\mu 1$ in TE buffer)

RNeasy Protect Saliva Mini Kit

- RNAprotect Saliva Reagent

- Puffer RLT

- Puffer RW1

- Puffer RDD

- DNase I

- Puffer RPE

- RNase-freies Wasser

\section{Hersteller}

Qiagen, Hilden

Promega, Mannheim

MRC Holland, Amsterdam (Niederlande)

Stratagene, La Jolla (USA)

Qiagen, Hilden 


\section{Kit}

Oligo (dT) ${ }_{12-18}$ Primer

One Step RT-PCR Kit

- RNase-freies Wasser

- 5x OneStep RT PCR-Puffer

- OneStep RT-PCR Enzym Mix

Wizard SV Gel and PCR Clean-Up System

- Membrane Binding Solution

- Membrane Wash Solution

\section{Hersteller}

Invitrogen, Karlsruhe

Qiagen, Hilden

Promega, Mannheim

\subsubsection{Puffer und Lösungen}

Lösungen für den routinemäßigen Gebrauch wurden nach Sambrook et al. (1989) angesetzt. Es wurde DEPC-behandeltes oder bidestilliertes Wasser verwendet. Wenn nötig, wurden die Ansätze steril filtriert oder autoklaviert.

\section{Lösung}

DNTP-Mix (10 mM)

PBS (10x)

Puffer P1 (Resuspensionspuffer)

Puffer P2 (Lysepuffer)

Puffer P3 (Neutralisierungspuffer)

Puffer QBT

\section{Hersteller/ Zusammensetzung}

- $10 \mathrm{mM}$ dATP

- $10 \mathrm{mM} \mathrm{dCTP}$

- $10 \mathrm{mM}$ dGTP

- $10 \mathrm{mM}$ dTTP

- $\quad 1,37 \mathrm{M} \mathrm{NaCl}$

- $81 \mathrm{mM} \mathrm{Na}_{2} \mathrm{HPO}_{4}$

- $27 \mathrm{mM} \mathrm{KCl}$

- $14,7 \mathrm{mM} \mathrm{KH}_{2} \mathrm{PO}_{4}$

Qiagen, Hilden

- 50 mM Tris- $\mathrm{HCl}(\mathrm{pH} \mathrm{8,0)}$

- $10 \mathrm{mM}$ EDTA

- $100 \mu \mathrm{g} / \mathrm{ml}$ RNase A

Qiagen, Hilden

- $200 \mathrm{mM} \mathrm{NaOH}$

- $1 \% \mathrm{SDS}$

Qiagen, Hilden

- 3 M Kaliumacetat (pH 5,5)

Qiagen, Hilden

- $750 \mathrm{mM} \mathrm{NaCl}$

- $50 \mathrm{mM}$ MOPS (pH 7,0)

- $15 \%$ Isopropanol (v/v)

- $0,15 \%$ Triton X-100 (v/v) 
Puffer QN

Puregene Cell Lysis Solution

Stoppmix

TBE-Puffer (5x)

TE-Puffer (10x)
Qiagen, Hilden

- $1,6 \mathrm{M} \mathrm{NaCl}$

- 50 mM MOPS (pH 7,0)

- $15 \%$ Isopropanol

Qiagen, Hilden

- $15 \%$ Ficoll $400(\mathrm{w} / \mathrm{v})$

- $200 \mathrm{mM}$ EDTA

- $0,1 \%$ Orange $\mathrm{G}(\mathrm{w} / \mathrm{v})$

- 445 mM Tris-HCl (pH 8,0)

- 10 mM EDTA

- 445 mM Borsäure

- $\quad 10$ mM Tris-HCl (pH 8,0)

- 1 mM EDTA

\subsubsection{Kulturmedien}

Medium

LB-Medium (pH 7,5)

\section{Zusammensetzung}

- $1 \%$ Pepton

- $0,5 \%$ Hefe-Extrakt

- $1 \% \mathrm{NaCl}$

Das Medium wurde mit bidestilliertem Wasser angesetzt, autoklaviert und bei $4^{\circ} \mathrm{C}$ gelagert. Für die Bakterien-Selektion wurde Ampicillin in einer Endkonzentration von $1 \mu 1 / \mathrm{ml}$ zugegeben. Für LB-Agar wurde dem LB-Medium vor dem Autoklavieren 1,5\% (w/v) Agar zugesetzt. Nach Abkühlen auf ca. $40^{\circ} \mathrm{C}$ wurde Ampicillin in einer Endkonzentration von $1 \mu \mathrm{l} /$ $\mathrm{ml}$ zugesetzt. Der Agar wurde in sterile Petrischalen gegossen und bei $4^{\circ} \mathrm{C}$ gelagert. Für IPTG/X-Gal-LB-Agar wurden nach dem Abkühlen zusätzlich $100 \mu \mathrm{M}$ IPTG und 0,4\% (w/v) $\mathrm{X}-\mathrm{Gal}$ zugegeben.

\section{Medium}

NIH3T3-Zell-Medium

\section{Zusammensetzung}

- DMEM

- $10 \% \mathrm{FKS}$

- $0,5 \%$ Penicillin

- $\quad 0,5 \%$ Streptomycin

- 2 mM L-Glutamin 
S.O.C. Medium

\subsubsection{Plasmide}

$$
\begin{aligned}
& \text { Invitrogen, Karlsruhe } \\
& \text { - } 2 \% \text { Trypton } \\
& \text { - } \quad 0,5 \% \text { Hefe-Extrakt } \\
& \text { - } 10 \mathrm{mM} \mathrm{NaCl} \\
& \text { - } 2,5 \mathrm{mM} \mathrm{KCl} \\
& \text { - } 10 \mathrm{mM} \mathrm{MgCl}_{2} \\
& \text { - } 10 \mathrm{mM} \mathrm{MgSO}_{4} \\
& \text { - } 20 \mathrm{mM} \mathrm{Glucose}
\end{aligned}
$$

\section{Hersteller}

Promega, Mannheim

Applied Biosystems, Darmstadt

Applied Biosystems, Darmstadt

\section{Reporter}

\subsubsection{Bakterienstämme}

Für die Transformation von kompetenten Bakterien wurde der Escherichia coli-Stamm K12 DH5 $\alpha$ der Firma Invitrogen (Karlsruhe) verwendet. Die Bakterien wurden in Aliquots von 50 $\mu 1$ bei $-80^{\circ} \mathrm{C}$ gelagert.

\subsubsection{Eukaryotische Zelllinien}

Für die Transfektion mit dem pMIR REPORT-Vektorsystem wurden NIH3T3-Zellen (embryonale Mausfibroblasten) (Jainchill et al. 1969) der Firma ATCC (Rockville, USA) eingesetzt.

\subsubsection{Synthetische Oligonukleotide}

Oligonukleotide (Primer) dienen als Startpunkte für die DNA-Amplifikation mittels Polymerase-Ketten-Reaktion. Alle verwendeten Primer wurden von Operon Biotechnologies (Köln) in einer Konzentration von 100 pmol/ $\mu 1$ bezogen.

Die folgende Auflistung zeigt Primer, die für die Sequenzanalyse des SPG31-Gens verwendet wurden. 


\author{
Primer-Name \\ $S P G 31$ Exon $1 \mathrm{f}$ \\ SPG31 Exon $1 \mathrm{r}$ \\ $S P G 31$ Exon $2 \mathrm{f}$ \\ SPG31 Exon $2 \mathrm{r}$ \\ $S P G 31$ Exon $3 \mathrm{f}$ \\ SPG31 Exon $3 \mathrm{r}$ \\ $S P G 31$ Exon $4 \mathrm{f}$ \\ $S P G 31$ Exon $4 \mathrm{r}$ \\ $S P G 31$ Exon $5 \mathrm{f}$ \\ SPG31 Exon $5 \mathrm{r}$ \\ SPG31 Exon $6 \mathrm{f}$ \\ SPG31 Exon $6 \mathrm{r}$ \\ $S P G 31$ Exon $7 \mathrm{f}$ \\ SPG31 Exon $7 \mathrm{r}$
}

\section{Oligonukleotidsequenz}

5'-CCG TGA GCT GAC TGA CGT T-3'

5'-GGC GGC TAC TGT ACC TGC TA-3'

5'-TGG GTG TGG GCT TTA ACA GAA GAT-3'

5'-GAA CTC CTT TTC CCT GCT TCC AGT-3'

5'-TTC AGC CTG AGT CAG TTG TGG AAC-3'

5'-GTT AAC ATC CCT GCT CTT GCG TCT-3'

5'-TAG GTG GAG GAC AGA GGA ATC TGG-3'

5'-GAA GGA AAT TCA CTT TGC GTG GTT-3'

5'-CTG TAT CTC TGC TCT CCC CTC TGC-3'

5'-CCA CTG ATT GGT CCT TAG CCT GTT-3'

5'-CTG ACC ATC AGA GCT CCC TCT TG-3'

5'-CCC CAG ACA ATC ATA TGG AGG AAA-3'

5'-GAG CTG GAA GTC TCA ACA C-3'

5'-GGT GCT GTT GGC TCA TCT C-3'

Bei den folgenden Oligonukleotidsequenzen handelt es sich um Primer zur Amplifikation des Housekeeping-Gens HPRT, welches für die Hypoxanthin-Phosphoribosyl-Transferase codiert. Die Amplifikation dieses Gens diente als Positivkontrolle bei der Untersuchung von cDNA mittels PCR.

\section{Primer-Name}

HPRT-F

HPRT-R

\section{Oligonukleotidsequenz}

5'-TCC TCC TCC TGA GCA GTC A-3'

5'-CTT GAG CAC ACA GAG GGC TA-3'

Im Folgenden sind Primer für die Amplifikation von Teilen der SPG31-cDNA dargestellt. Die beiden forward-Primer (F) können beliebig mit den reverse-Primern (R) kombiniert werden.

\author{
Primer-Name \\ SPG31-cDNAP1_F \\ SPG31-cDNA P2_F \\ SPG31-cDNA Ex4R \\ SPG31-cDNA Ex5R \\ SPG31-cDNA-Ex6R \\ SPG31-cDNA-Ex7R
}

\section{Oligonukleotidsequenz}

5'-TGG CAC CCT TTA CCC TGC GTA TTA-3'

5'-TCC CAC ACT ATC TTC AAA AGA AAA GGA-3'

5'-GAC AGC AGC CAG GCT ACA AAT GCT-3'

5'-CCA CGT TCA AGC CCC GCT TCC-3'

5'-GGA CAG GGT GCC TTA TCG GAG A-3'

5'-GAA TCC TTC GAT CTC GCT TCA GGA-3' 
Folgende Primer wurden für die Amplifikation eines 679 bp-langen Abschnitts von Exon 7 des SPG31-Gens mit angrenzender 3'UTR verwendet.

\section{Primer-Name}

3'UTR_F

3'UTR_R
Oligonukleotidsequenz

5'-AAG CTT GGA GCT GGA AGT CTC AAC ACA ATG C-3' 5'-GAG CTC ATA TCA GAA CCT CTG GCA GCC CTT G-3'

Da das PCR-Produkt später in den Vektor pMIR Report ligiert werden sollte, wurden an die 5'-Enden der Primer Schnittstellen für die Restriktionsenzyme HindIII bzw. SstI angehängt. Die nicht-sequenzspezifischen pallindromischen Sequenzen, die von den Restriktionsenzymen erkannt und geschnitten werden, sind grau hinterlegt.

Die Primer T7 und Sp6 dienten als Standardprimer zur Amplifikation von pGEM-T Easy und Inserts. Im Folgenden ist die Sequenz dieser Primer dargestellt.

\section{Primer-Name}

$\mathrm{T} 7$

Sp6

\section{Oligonukleotidsequenz}

5'-TAA TAC GAC TCA CTA TAG GG-3'

5'-CAT ACG ATT TAG GTG ACA CTA TAG-3'

Die folgenden Primer dienten der Amplifikation von Teilen des pMIR REPORT miRNA Expression Reporters inklusive Inserts.

\author{
Primer-Name \\ Oligonukleotidsequenz \\ pMIR-F \\ 5'-AGG GCG GAA AGT CCA AAT TGC-3' \\ pMIR-R \\ 5'-CAT ACA AAA AAC CAA CAC ACA GAT CC-3'
}

\title{
2.1.11 Messenger-RNA
}

Die in dieser Arbeit verwendete Kontroll-RNA First Choice Human Brain Reference RNA aus menschlichem Gehirn wurde von der Firma Applied Biosystems (Darmstadt) bezogen.

\subsubsection{Micro-RNAs}

Micro-RNAs sind ca. 25 bp-lange RNA-Fragmente im menschlichen Organismus, die Transkriptions-regulatorische Funktion besitzen. Sie sind mit den small interfering-RNAs (siRNA) der Pflanzen verwandt. Die in dieser Arbeit verwendete miR-691 wurde von der 
Firma Qiagen (Hilden) bezogen, die Negative Control \#1 Pre-miR stammt von Applied Biosystems (Darmstadt).

\subsubsection{Blut- bzw. DNA-Proben}

Voraussetzung für die SPG31-Diagnostik war ein autosomal dominanter Erbgang und der Ausschluss von Mutationen in den beiden am häufigsten veränderten HSP-Genen $S P G 3 A$ und SPG4. Das dritte Kriterium war das Vorliegen eines unkomplizierten Phänotyps. Um die Erfüllung dieser Kriterien sicherzustellen, wurde für alle Patienten ein Fragebogen erstellt, der vom überweisenden Arzt oder im Rahmen der genetischen Beratung ausgefüllt wurde. Die Patienten haben nach ausführlicher Beratung schriftlich in die genetische Testung eingewilligt. Für die Diagnostik wurden ihnen $10 \mathrm{ml}$ EDTA-Blut abgenommen. Nach aktuellem Gendiagnostikgesetz wurden die Proben nur für die SPG-Diagnostik gewonnen, verwendet und nach Abschluss der Diagnostik unverzüglich vernichtet. Die Patientenproben wurden mithilfe von DNA-Nummern anonymisiert. Sequenzierungs- und MLPA-Ergebnisse sowie Daten zur Klinik und ein Stammbaum wurden unter diesen Nummern in Tabellen abgelegt und im Rahmen dieser Arbeit ausgewertet.

Neben den Patienten-Blutproben wurden verschiedene Gewebe und Materialien von gesunden Probanden gewonnen. Diese Personen spendeten ausdrücklich freiwillig und ohne finanzielle Anreize. Alle gewonnenen Proben wurden anonymisiert und unverzüglich nach Abschluss der Untersuchungen vernichtet.

\subsubsection{Geräte}

\section{Gerät}

Autoklav

BioPhotometer RS 232C

$\mathrm{CO}_{2}$-Inkubator

Gellaufkammer

Genetic Analyzer 3130

Inkubator Clim-O-Shake

Inkubator Memmert

Luminometer SynergyMx

Magnetrührer

\section{Hersteller}

Webeco, Bad Schwartau

Eppendorf, Hamburg

Sanyo GmbH, München

Krannich, Göttingen

Applied Biosystems, Darmstadt

Kühner, Basel (Schweiz)

Krannich, Göttingen

BioTek, Bad Friedrichshall

Schütt Labortechnik, Göttingen 


\section{Gerät}

MegaBACE 1000 Sequencer

Neubauer Zählkammer

Pipetten

Spannungsgerät

Thermal-Cycler: Primus 25

PTC-100

Thermomixer 5436

UV-Arbeitsbank

UV-Transilluminator UVT-28M

Vortex Genie 2

Waagen

Wasserbad

Zellkulturbank Heraeus HERA Safe

Zentrifugen: Heraeus Megafuge $1.0 \mathrm{R}$

Mini Centrifuge GMC- LMS Consult GmbH \& Co. KG, Brigachtal 060

Sigma 4K15

\section{Hersteller}

Amersham Pharmacia Biotech, Freiburg

Schütt Labortechnik, Göttingen

Gilson, Middleton (USA)

Eppendorf, Hamburg

Pharmacia, New York (USA)

Peqlab, Erlangen

MJ Research, Waltham (USA)

Eppendorf, Hamburg

Krannich, Göttingen

Herolab GmbH, Wiesloch

Bender \& Hobein AG, Zürich (Schweiz)

Sartorius, Göttingen

Köttermann, Uetze/Hänigsen

Kendro Laboratory Products GmbH, Langenselbold

Eppendorf, Hamburg

Sigma Laboratory Centrifuges, Osterode im Harz

\subsubsection{Verbrauchsmaterialien}

Gebrauchswaren, die in der folgenden Auflistung fehlen, wurden von den Firmen OmnilabKrannich (Göttingen) und Schütt (Göttingen) bezogen. Die unsterilen Glaswaren und hitzestabilen Verbrauchsmaterialien wurden in einem Autoklav (Webeco, Bad Schwartau) bei $121^{\circ} \mathrm{C}$ und $100 \mathrm{kPa}$ für 20 min sterilisiert.

\section{Material}

10-ml-Falcons

24-Well Zellkultur-Platten

50-ml-Polypropylenröhrchen

96-Well PCR-Platten

Invisorb MSB Spin PCRaspace

NucleoFast Aufreinigungsplatten

\section{Hersteller}

Eppendorf, Hamburg

Greiner, Nürtingen

Sarstedt Aktiengesellschaft \& Co., Nümbrecht Sarstedt Aktiengesellschaft \& Co., Nümbrecht Invitrogen, Karlsruhe

Clontech Laboratories Inc., Saint-Germain-enLaye (Frankreich) 


\section{Material}

PCR Reaktionsgefäße

Petrischalen

Pipettenspitzen

Quarz-Küvette $10 \mathrm{~mm}$

Sterilfilter

Zellkulturflaschen

\section{Hersteller}

Sarstedt Aktiengesellschaft \& Co., Nümbrecht

Greiner, Nürtingen

Eppendorf, Hamburg

Hellma Analytics, Müllheim

Sartorius, Göttingen

Greiner, Nürtingen

\subsubsection{Software und Datenbanken}

Zur Auswertung von DNA-Sequenzanalysen wurde das Programm Seq Pilot (JSI medical systems GmbH, Kippenheim) verwendet. Die Auswertung von MLPA-Analysen erfolgte mithilfe der Gene Marker-Software der Firma Softgenetics (State College, USA). Die Bedienung des Luminometers erfolgte über die Software Gene5 der Firma BioTek (Bad Friedrichshall), die Auswertung der Lumineszenz-Messungen erfolgte mit dem Tabellenkalkulations-Programm Microsoft Excel 2000.

Nukleotid- und Proteinsequenzen wurden mit den Sequenzdatenbanken Genbank (http://www.ncbi.nlm.nih.gov/guide) und Ensembl (http://www.ensembl.org/index.html), sowie mithilfe des Programmes BLAST des National Center for Biotechnology Information (http://blast.ncbi.nlm.nih.gov/) analysiert. Informationen zu miRNAs und den entsprechenden Nucleotidsequenzen wurden über die Micro-RNA-Datenbank miRBase (http://www.mirbase.org) bezogen. Der New England Biolabs Cutter 2.0 (http://tools.neb.com/NEBcutter2/) wurde verwendet, um Restriktionsschnittstellen innerhalb von Nukleinsäuresequenzen $\mathrm{zu}$ finden. Zur Generierung von Oligonukleotiden kam das Programm Primer3 (http://frodo.wi.mit.edu/primer3/) zum Einsatz. Um reverskomplementäre Sequenzen $\mathrm{zu}$ erzeugen, wurde die Software Reverse Complement (http://www.bioinformatics.org/sms/rev_comp.html) verwendet. Die Analyse von Splice-SiteMutationen wurde mithilfe der Internetseite des Berkeley Drosophila Genome Project (http://www.fruitfly.org/seq tools/splice.html) durchgeführt. Mithilfe der Human Gene Mutation Database (HGMD) (https://portal.biobase-international.com/hgmd/pro/gene.php? gene=REEP1) wurden alle bisher beschriebenen Mutationen im SPG31-Gen identifiziert. 


\subsection{Methoden}

\subsubsection{DNA-Präparation aus Leukozyten des peripheren Blutes}

Zunächst wurden $10 \mathrm{ml}$ EDTA-Blut zum Lysieren der Erythrozyten mit $30 \mathrm{ml} 4^{\circ} \mathrm{C}$ kalter Puregene Cell Lysis Solution in einem Polypropylenröhrchen vermischt und für 30 min auf Eis inkubiert. Danach wurde das Lysat zentrifugiert (2000 x g, 15 min), der Überstand wurde abgenommen und verworfen. Das Leukozytenpellet wurde erneut in $30 \mathrm{ml}$ Lysepuffer resuspendiert. Dieser Vorgang wurde so oft wiederholt, bis im Leukozytenpellet keine rötliche Färbung mehr sichtbar war. Anschließend wurden die Leukozyten in $5 \mathrm{ml}$ SE-Puffer resuspendiert. Nach Zugabe von $250 \mu$ Proteinase K (10 mg/ml) und $500 \mu 1$ 10\% SDS folgte eine Inkubation bei $55^{\circ} \mathrm{C}$ im Wasserbad über Nacht. Dabei zerstörte das SDS die Zellmembranen und die Proteinase $\mathrm{K}$ baute freigesetzte zelluläre Proteine ab. Nach der Proteolyse wurden $1,5 \mathrm{ml}$ gesättigte $\mathrm{NaCl}$-Lösung hinzugegeben. Nach $15 \mathrm{sec}$ Vortexen schloss sich eine Zentrifugation an (3000 x g, RT, 15 min). Die DNA im Überstand wurde in ein neues Röhrchen gegeben und mit 1,3 ml Glykogen versetzt. Dann konnte die DNA mittels 2 Volumina 100\%-Ethanol ausgefällt werden (Inkubation $-20^{\circ} \mathrm{C}, 3 \mathrm{~h}$ ). Die DNA-Knäuel wurden mit $500 \mu \mathrm{l}$ 70\%-Ethanol gewaschen und, nachdem das Ethanol abgedampft war, in $500 \mu 11$ x TE-Puffer gelöst. Bis zur weiteren Verwendung wurden die Proben bei einer Temperatur von maximal $4^{\circ} \mathrm{C}$ gelagert.

\subsubsection{RNA-Präparation}

\subsubsection{Isolation von Gesamt-RNA aus Leukozyten des peripheren Blutes mithilfe der Phenol-Chloroform-Methode}

Zur Isolation von Gesamt-RNA wurde eine modifizierte Phenol-Chloroform Aufreinigung nach Chomczynski und Sacchi (1987) durchgeführt. Dazu wurde zunächst EDTA-Blut im Verhältnis von 1:5 mit Puregene Cell Lysis Solution versetzt. Nach gründlichem Mischen erfolgte eine Inkubation für 20 min auf Eis. Um eine gleichmäßige Verteilung des Puffers zu gewährleisten, wurden die Röhrchen alle 5 min geschwenkt. Zur Trennung des Zell-Detritus vom Leukozyten-Pellet wurden die Röhrchen zentrifugiert $\left(2000 \times \mathrm{g}, 4^{\circ} \mathrm{C}, 10 \mathrm{~min}\right)$. Der

Überstand wurde verworfen. Die Leukozyten wurden mit $1 \mathrm{ml}$ peq GOLD TriFast resuspendiert und in 1,5 ml Reaktionsgefäße überführt. Nach einer fünfminütigen Inkubation 
bei RT wurden $200 \mu$ l Chloroform zugegeben und das verschlossene Cup wurde für 15-20 sec geschüttelt. Es folgte eine Inkubation für $10 \mathrm{~min}$ bei RT. Um die entstandenen Phasen voneinander trennen zu können, schloss sich eine Zentrifugation $\left(10000 \mathrm{x} \mathrm{g}, 4^{\circ} \mathrm{C}, 15 \mathrm{~min}\right)$ an. Die obere klare Schicht enthielt die RNA, die mittlere weiße Schicht bestand aus Proteinen und in der unteren rosafarbenen Phase befand sich die DNA. Die RNA-Phase wurde in ein neues Eppendorf-Reaktionsgefäß überführt, mit $500 \mu 1$ Isopropanol ausgefällt und $10 \mathrm{~min}$ bei RT inkubiert. Durch Zentrifugation $\left(10000 \mathrm{x} \mathrm{g}, 4^{\circ} \mathrm{C}, 10 \mathrm{~min}\right)$ entstand ein RNA-Pellet. Der Überstand wurde verworfen und das RNA-Pellet in $500 \mu 1$ 70\%-Ethanol gelöst. Nach erneuter Zentrifugation $\left(10000 \mathrm{xg}, 4^{\circ} \mathrm{C}, 5 \mathrm{~min}\right)$ konnte der Ethanol-Überstand abgenommen und verworfen werden. Das Pellet wurde bei RT 5-10 min getrocket. Schließlich wurde die RNA in $20 \mu 1 \mathrm{RNase}$-freiem Wasser gelöst und bis zur weiteren Verwendung bei $-80^{\circ} \mathrm{C}$ gelagert.

\subsubsection{Isolierung von Gesamt-RNA aus Zellen der Mundschleimhaut und des Speichels}

Die Materialgewinnung erfolgte nach gängigem Protokoll (Navazesh 1993). Die Probanden wurden gebeten, eine Stunde lang nicht zu essen, nicht zu trinken und nicht zu rauchen. Der Mund wurde zunächst mit sterilem Wasser ausgespült, dann wurden Zellen der Mundschleimhaut im Bereich der Wangentaschen mit einem speziellen Löffel abgeschilfert. Nach fünfminütiger Sammelperiode wurde der Speichel in ein steriles Falcon-Röhrchen überführt und sofort auf Eis gestellt.

Zur Phenol-Chloroform Aufreinigung (Chomczynski und Sacchi 1987) wurde der Speichel zunächst zentrifugiert $\left(1500 \mathrm{x} \mathrm{g}, 4^{\circ} \mathrm{C}, 10 \mathrm{~min}\right)$. Das Pellet wurde in $1 \mathrm{ml}$ TriFast-Reagenz gelöst und der Überstand verworfen. Nach einer Inkubation bei RT für 20 min wurde, wie unter 2.2.2.1 beschrieben, weiter vorgegangen.

Bei der Isolation mittels Qiagen RNeasy Saliva Protect wurden entsprechend Herstellerprotokoll jeweils $200 \mu \mathrm{l}$ Speichel mit $1 \mathrm{ml}$ RNAprotect Saliva Reagent vermischt und bei $4^{\circ} \mathrm{C}$ für $24 \mathrm{~h}$ unter ständiger Bewegung inkubiert. Nach Überführen der Lösung in ein Eppendorf-Reaktionsgefäß wurden die Zellen abzentrifugiert $\left(10000 \mathrm{x} \mathrm{g}, 4^{\circ} \mathrm{C}, 20 \mathrm{~min}\right)$, der Überstand wurde vorsichtig abpipettiert. Nach Lösen des Pellets in $350 \mu$ Puffer RLT wurden $350 \mu 1$ 70\%-Ethanol zugegeben. Der Inhalt des Reaktionsgefäßes wurde in eine Filtersäule überführt, welche in ein $2 \mathrm{ml}$-Cup gesetzt wurde. Nach dem Zentrifugieren ( $8000 \mathrm{x} \mathrm{g}, 30 \mathrm{sec}$ ) wurde die Flüssigkeit im Sammelröhrchen verworfen und es wurden $350 \mu$ l Puffer RW1 auf die Membran der Säule pipettiert. Es folgte eine weitere Zentrifugation (8000 x g, $30 \mathrm{sec}$ ). 
Die Flüssigkeit im Sammelröhrchen wurde verworfen.

Um die auf der Membran vorhandene DNA $\mathrm{zu}$ verdauen, wurden $10 \mu 1$ DNase I stock solution mit $70 \mu \mathrm{l}$ Puffer RDD vermischt und direkt auf die Membran der Filtersäule gegeben. Der 15-minütige Verdau wurde in einem Inkubator bei $30^{\circ} \mathrm{C}$ durchgeführt. Anschließend wurden $350 \mu$ Puffer RW1 in die Filtersäule gegeben und erneut zentrifugiert $(8000 \mathrm{xg}, 30 \mathrm{sec})$. Die Säule wurde in ein neues $2 \mathrm{ml}$-Sammelröhrchen überführt. $500 \mu l$ Puffer RPE wurden auf die Säule gegeben und zentrifugiert ( 8000 x g, $30 \mathrm{sec}$ ). Der Durchfluss wurde verworfen. Zur weiteren Aufreinigung der RNA wurden $500 \mu 1$ $80 \%$-Ethanol auf die Säule gegeben und $2 \mathrm{~min}$ bei $8000 \mathrm{xg}$ zentrifugiert, das Sammelröhrchen konnte anschließend verworfen werden. In einem neuen $2 \mathrm{ml}$ Sammelröhrchen wurde mit offenem Deckel bei maximaler Geschwindigkeit weitere 5 min zentrifugiert, um das restliche Ethanol verdampfen zu lassen. Die Filtersäule wurde in ein 1,5 ml Eppendorf-Cup gesetzt. $20 \mu \mathrm{l}$ RNase-freies Wasser wurden in die Mitte des Filters gegeben und für 2 min bei $37^{\circ} \mathrm{C}$ inkubiert. Bei einer erneuten Zentrifugation (maximale Geschwindigkeit, RT, 2 min) löste sich die RNA aus der Membran. Bis zur weiteren Verwendung wurde die RNA bei $-80^{\circ} \mathrm{C}$ gelagert.

\subsubsection{Isolierung von Gesamt-RNA aus Epithelzellen im Urin}

Frischer Mittelstrahlurin wurde in sterilen $50 \mathrm{ml-Falcon-Röhrchen} \mathrm{gesammelt} \mathrm{und}$ zentrifugiert $\left(3000 \mathrm{x} \mathrm{g}, 4^{\circ} \mathrm{C}, 30 \mathrm{~min}\right)$. Der Überstand wurde verworfen, das Zell-Pellet mit $1 \mathrm{ml}$ peq GOLD TriFast resuspendiert, in ein 1,5 ml Eppendorf-Cup überführt und 5 min bei RT inkubiert. Das weitere Vorgehen erfolgte analog zu 2.2.2.1.

\subsubsection{Isolierung von Gesamt-RNA aus Haarwurzeln}

Mithilfe einer Pinzette wurden 5-10 Haupthaare mitsamt Wurzel ausgezupft. Diese wurden von der Wurzel ausgehend auf 5-10 mm Länge gekürzt, in ein 1,5 ml-Eppendorf-Cup überführt und mit $500 \mu \mathrm{l}$ peq GOLD TriFast versetzt. Mit einem manuellen Homogenisator wurden die Haarwurzeln zerdrückt. Es wurden nochmals $500 \mu 1$ peq GOLD TriFast hinzugegeben. Es folgte eine 30-minütige Inkubation auf Eis. Das weitere Vorgehen erfolgte wie in Kapitel 2.2.2.1 beschrieben. 


\subsubsection{Isolierung bakterieller Plasmide}

\subsubsection{Mini-Plasmid-Präparation}

Um geringe Mengen Plasmid-DNA (analytischer Maßstab) aus Bakterien zu isolieren, wurde eine modifizierte alkalische Lyse mithilfe der Qiagen Buffer for Plasmid-Isolation durchgeführt (Birnboim und Doly 1979, Sambrook et al. 1989).

Die angeimpften Übernacht-Kulturen enthielten Bakterien in einer Konzentration von 3-4 x 109/ml. Es wurden $2 \mathrm{ml}$ der Kultur in Eppendorf-Reaktionsgefäße überführt und abzentrifugiert (13000 x g, RT, 1 min). Der Überstand wurde verworfen. Die Zellen wurden mit $150 \mu 1 \mathrm{P} 1$ (Resuspensionspuffer mit Tris-HCl, EDTA und RNase A) versetzt und mittels Vortex resuspendiert. Durch Zugabe von $300 \mu 1$ P2 (Lysepuffer, enthält NaOH und SDS) und 5-minütige Inkubation bei RT wurden die Protein- und Phospholipid-Anteile der Bakterienzellmembran aufgelöst. Durch die RNase A wurde die freigesetzte RNA verdaut. $\mathrm{NaOH}$ führte zur Denaturierung von chromosomaler- und Plasmid-DNA. Schließlich wurden mithilfe von $200 \mu \mathrm{l}$ P3 (Neutralisationspuffer, enthält Kaliumacetat) Proteine und Zellmembranbestandteile ausgefällt. Um diese Präzipitate $\mathrm{zu}$ entfernen, folgte eine Zentrifugation (13000 x g, 20 min). Die im Überstand enthaltene Plasmid-DNA wurde in ein 1,5 ml Eppendorf-Reaktionsgefäß überführt, zentrifugiert $\left(13000 \times \mathrm{g} 4^{\circ} \mathrm{C}, 20 \mathrm{~min}\right)$ und in ein neues Reaktionsgefäß gegeben. Die Zugabe von 70\%-Ethanol im Verhältnis 7:10 (v/v) führte zur Präzipitation der Plasmid-DNA. Nach sorgfältigem Schwenken wurde die Probe 30 min auf Eis inkubiert und anschließend nochmals zentrifugiert $\left(13000 \mathrm{xg}, 4^{\circ} \mathrm{C}, 30 \mathrm{~min}\right)$. Der Überstand wurde verworfen, das Pellet in $300 \mu 170 \%$-Ethanol gelöst und erneut zentrifugiert (13000 x g, $\left.4^{\circ} \mathrm{C}, 15 \mathrm{~min}\right)$. Nach Abpipettieren des Überstandes wurde das DNA-Pellet $10 \mathrm{~min}$ bei RT getrocknet, in $30 \mu \mathrm{l}$ Ampuwa resuspendiert und bis zur weiteren Verwendung bei $-20^{\circ} \mathrm{C}$ gelagert.

\subsubsection{Maxi-Plasmid-Präparation}

Um hochreine Plasmid-DNA in präparativem Maßstab zu gewinnen, wurde das Endofree Plasmid Maxi Kit entsprechend Herstellerhinweisen verwendet. Bei diesem Verfahren erfolgt mithilfe von Filtersäulen eine affinitäts-chromatographische Auftrennung.

Zur Vorbereitung wurden $200 \mu 1$ eines Glycerin-Stocks mit transformierten Bakterien in $200 \mathrm{ml}$ LB-Medium mit $200 \mu \mathrm{l}$ Ampicillin bei $37^{\circ} \mathrm{C}$ für $8-12 \mathrm{~h}$ unter ständiger Bewegung 
bebrütet. Anschließend wurden die Bakterien abzentrifugiert $\left(6000\right.$ x g, $\left.4{ }^{\circ} \mathrm{C}, 15 \mathrm{~min}\right)$. Nach Abnehmen des Überstandes wurden sie in $10 \mathrm{ml}$ Puffer P1 resuspendiert. Durch Zugabe von $10 \mathrm{ml}$ Puffer P2 und fünfminütige Inkubation bei RT wurde die Bakterienmembran zerstört. Nach Zusetzen von $10 \mathrm{ml}$ Puffer P3 und Schwenken der Probe fielen die Membranbestandteile aus. Im QIAfilter stieg der ausgefällte Zelldetritus an die Oberfläche und das Lysat, in dem die Plasmid-DNA gelöst war, konnte abfiltriert werden. In der Probe enthaltene Endotoxine wurden durch 2,5 ml Puffer ER während einer 30-minütigen Inkubation auf Eis gebunden. Währenddessen wurde der Qiagen-tip-Filter mit $10 \mathrm{ml}$ Puffer QBT aktiviert. Anschließend wurde die Probe auf den Filter überführt. Die DNA wurde in der Filtermembran gebunden. Die übrigen Zellbestandteile und gebundenen Endotoxine wurden durch das zweimalige Waschen mit $30 \mathrm{ml}$ Puffer QC entfernt. Der Qiagen-tip wurde in ein neues $50 \mathrm{ml}$-Polypropylen-Röhrchen gesetzt. Die Zugabe von $15 \mathrm{ml}$ des auf $65^{\circ} \mathrm{C}$ vorgewärmten Puffers QN löste die DNA aus der Filtermembran. Um die DNA auszufällen, wurden 10,5 ml Isopropanol zugesetzt. Der Ansatz wurde $30 \mathrm{~min}$ auf Eis inkubiert, bevor die DNA abzentrifugiert wurde $\left(5000 \mathrm{x} \mathrm{g}, 4^{\circ} \mathrm{C}, 60 \mathrm{~min}\right)$. Der Überstand wurde verworfen und die DNA mit $5 \mathrm{ml}$ 70\%-igem endotoxinfreiem Ethanol gewaschen. Nach einer erneuten Zentrifugation $\left(5000 \mathrm{x} \mathrm{g}, 4^{\circ} \mathrm{C}, 60 \mathrm{~min}\right)$ wurde das Pellet $30 \mathrm{~min}$ an der Luft getrocknet und schließlich in $150 \mu 1 \mathrm{TE}$ resuspendiert.

\subsubsection{Konzentrationsbestimmung von Nukleinsäuren}

Die Konzentrationen der Nukleinsäuren wurden durch eine photometrische Messung bestimmt. Dafür wurden $4 \mu \mathrm{l}$ der DNA- bzw. RNA-Lösung in $396 \mu$ Ampuwa verdünnt. Zunächst erfolgte eine Nullkalibrierung des Photometers gegen Ampuwa, anschließend die Konzentrationsbestimmung der verdünnten RNA- bzw. DNA-Lösung. Die Extinktion (E) der Proben wurde bei $260 \mathrm{~nm}$ und $280 \mathrm{~nm}$ gemessen. Die Berechnung der Konzentration (c) der Proben erfolgte nach dem „Lambert'schen Gesetz“( (s. Abb. 3): 


$$
\mathrm{C}=(\mathrm{E} 260 \mathrm{~nm}-\mathrm{E} 280 \mathrm{~nm}) \times \mathrm{f} \times \mathrm{c}
$$

Abb. 3: Lambert'sches Gesetz.

C: Konzentration der Probe $(\mu \mathrm{g} / \mu \mathrm{l})$, E260 nm: Extinktion bei $260 \mathrm{~nm}$, E280 nm: Extinktion bei $280 \mathrm{~nm}$, f: Verdünnungsfaktor, c: Konzentrationskonstante bei einer Schichtdicke von $1 \mathrm{~cm}$ und einer Extinktion von 1 (für RNA c $=40 \mu \mathrm{g} / \mathrm{ml}$, für dsDNA c $=50 \mu \mathrm{g} / \mathrm{ml}$ )

\subsubsection{Polymerasekettenreaktion (PCR)}

Die Polymerasekettenreaktion dient dazu, Genabschnitte spezifisch zu vervielfältigen (Saiki et al. 1988). Dazu werden Primer verwendet, die spezifisch an die denaturierte DNA binden können (Annealing). An das 3'-Ende der Primer werden durch eine hitzestabile Polymerase komplementär zur Matritzen-DNA energiereiche Desoxynukleotide angelagert und so neue DNA-Stränge synthetisiert (Extension). Um doppelsträngige DNA-Kopien zu erhalten, werden jeweils Vorwärts- und Rückwärtsprimer eingesetzt.

\subsubsection{Primerauswahl}

Primer sind Oligonukleotid-Sequenzen, die sich an komplementäre DNA-Einzelstränge anlagern können und als Startpunkt für eine hitzestabile DNA-Polymerase bei der PCR dienen.

Die Sequenzen ENSG00000068615 aus der Ensembl-Datenbank (http://ensembl.genomics.org.cn:8057/index.html) bzw. NG_013037.1 aus der Genbank (http://www.ncbi.nlm.nih.gov/gene/?term=spg31) wurden als Referenzsequenzen für das Gen SPG31 übernommen. Die Sequenzen der sieben kodierenden Exons des Gens wurden mitsamt der flankierenden Abschnitte kopiert und auf der Internetseite Primer3 (http://frodo.wi.mit.edu/primer3/input.htm) in das entsprechende Feld eingefügt. Mit der Zeichenfolge „[ ]“ wurde der Bereich markiert, der in jedem Fall von den Primern umschlossen werden sollte. Anschließend wurden die in der Tabelle 2 folgenden Bedingungen festgelegt: 
Tab. 2: Strenge Parameter für die Primerauswahl mit Primer3.

\begin{tabular}{|l|l|}
\hline Parameter & Verwendete Werte \\
\hline Primer Size & $25-27 \mathrm{bp}$ \\
\hline Primer Tm & $65-70^{\circ} \mathrm{C}$ \\
\hline Max Tm Difference & $0,5^{\circ} \mathrm{C}$ \\
\hline Product Tm & $75-85^{\circ} \mathrm{C}$ \\
\hline Primer GC $\%$ & $50-70 \%$ \\
\hline
\end{tabular}

Für die übrigen Bedingungen wurden voreingestellte Werte übernommen. In einigen Fällen konnte unter o.g. Bedingungen kein Primer gefunden werden, dann wurden die in Tabelle 3 genannten, weniger stringenten Parameter gewählt:

Tab. 3: Weniger strenge Parameter für die Primerauswahl mit Primer3.

\begin{tabular}{|l|l|}
\hline Parameter & Verwendete Werte \\
\hline Primer Size & $21-27 \mathrm{bp}$ \\
\hline Primer Tm & $55-80^{\circ} \mathrm{C}$ \\
\hline Max Tm Difference & $5^{\circ} \mathrm{C}$ \\
\hline Primer GC\% & $40-80 \%$ \\
\hline
\end{tabular}

Die gefundenen Primer-Sequenzen wurden nun mittels „Human BLAT Search“ (http://www.genome.ucsc.edu/cgi-bin/hgBlat?command=start) auf Homologien überprüft. Es wurden nur spezifische Primer für SPG31 gewählt, d.h. es gab beim Vergleich mit dem gesamten humanen Genom nur eine komplementäre Sequenz, nämlich die im SPG31-Gen.

\subsubsection{PCR-Ansätze}

Der folgende PCR-Ansatz mit Takara La Taq-DNA-Polymerase wurde nur für die Amplifikation des 1. SPG31-Exons verwendet.

$\begin{array}{ll}\text { Volumen } & \text { Reagenz } \\ 0,5 \mu 1 & \text { Primer F } \\ 0,5 \mu 1 & \text { Primer R } \\ 4 \mu 1 & \text { dNTPs } \\ 12,5 \mu 1 & 2 x \text { GC-Puffer } 1 \\ 0,25 \mu 1 & \text { Takara La Taq Polymerase } \\ 6,25 \mu 1 & \mathrm{H}_{2} \mathrm{O}\end{array}$


Der folgende Ansatz mit Immolase-DNA-Polymerase wurde für die übrigen PCRs verwendet.

$\begin{array}{ll}\text { Volumen } & \text { Reagenz } \\ 0,5 \mu \mathrm{l} & \text { Primer F } \\ 0,5 \mu \mathrm{l} & \text { Primer } \mathrm{R} \\ 0,5 \mu \mathrm{l} & \mathrm{dNTPs} \\ 0,75 \mu \mathrm{l} & \mathrm{MgCl}_{2} \\ 0,2 \mu \mathrm{l} & \text { Immolase DNA Polymerase }_{2,5 \mu \mathrm{l}} \\ 19,55 \mu \mathrm{l} & 10 x \text { Immo-Puffer } \\ \end{array}$

\subsubsection{PCR-Konditionen im Thermal-Cycler}

Die PCRs wurden in vollautomatischen Thermal-Cyclern durchgeführt. Die Zyklustemperaturen und Zeitintervalle für die einzelnen Schritte sind von verschiedenen Parametern abhängig. Sie richten sich nach der Länge des zu amplifizierenden DNAFragments sowie nach der spezifischen Anlagerungstemperatur der eingesetzten PCR-Primer und wurden in Versuchen optimiert.

Das PCR-Programm Touchdown 60 wurde bei der molekulargenetischen Analyse des SPG31-Gens für die Amplifikation der Exons 1-6 verwendet.

\begin{tabular}{|c|c|c|c|}
\hline Reaktionsschritt & Dauer & Temperatur & \\
\hline Denaturierung/Aktivierung: & $7 \mathrm{~min}$ & $96^{\circ} \mathrm{C}$ & \\
\hline Denaturierung: & $0,5 \mathrm{~min}$ & $96^{\circ} \mathrm{C}$ & 5 Zyklen, bei jedem \\
\hline Annealing: & $1 \mathrm{~min}$ & $65^{\circ} \mathrm{C}$ & Zyklus Annealing- \\
\hline Extension: & $1 \mathrm{~min}$ & $72^{\circ} \mathrm{C}$ & Temperatur $1^{\circ} \mathrm{C}$ niedriger \\
\hline Denaturierung: & $0,5 \min$ & $96^{\circ} \mathrm{C}$ & \\
\hline Annealing: & $1 \mathrm{~min}$ & $60^{\circ} \mathrm{C}$ & 30 Zyklen \\
\hline Extension: & $1 \mathrm{~min}$ & $72^{\circ} \mathrm{C}$ & \\
\hline Finale Extension: & $5 \mathrm{~min}$ & $72^{\circ} \mathrm{C}$ & \\
\hline
\end{tabular}

Das PCR-Programm Touchdown 58 kam bei der molekulargenetischen Analyse des SPG31Gens für die Amplifikation des Exons 7 zum Einsatz. 


$\left.\begin{array}{lll}\text { Reaktionsschritt } & \text { Dauer } & \text { Temperatur } \\ \text { Denaturierung/Aktivierung: } & 7 \mathrm{~min} & 96^{\circ} \mathrm{C} \\ \text { Denaturierung: } & 0,5 \mathrm{~min} & 96^{\circ} \mathrm{C} \\ \text { Annealing: } & 1 \mathrm{~min} & 63^{\circ} \mathrm{C} \\ \text { Extension: } & 1 \mathrm{~min} & 72^{\circ} \mathrm{C} \\ \text { Denaturierung: } & 0,5 \mathrm{~min} & 96^{\circ} \mathrm{C} \\ \text { Annealing: } & 1 \mathrm{~min} & 58^{\circ} \mathrm{C} \\ \text { Extension: } & 1 \mathrm{~min} & 72^{\circ} \mathrm{C} \\ \text { Finale Extension: } & 5 \mathrm{~min} & 72^{\circ} \mathrm{C}\end{array}\right\} \begin{aligned} & 5 \text { Zyklen, bei jedem } \\ & \text { Zyklus Annealing- } \\ & \text { Temperatur } 1{ }^{\circ} \mathrm{C} \text { niedriger }\end{aligned}$

Das folgende PCR-Programm Touchdown 62 wurde in Kombination mit cDNA-Primern zur Vervielfältigung bestimmter Abschnitte der SPG31-cDNA verwendet.

$\left.\begin{array}{lll}\text { Reaktionsschritt } & \text { Dauer } & \text { Temperatur } \\ \text { Denaturierung/Aktivierung: } & 7 \mathrm{~min} & 96^{\circ} \mathrm{C} \\ \text { Denaturierung: } & 0,5 \mathrm{~min} & 96^{\circ} \mathrm{C} \\ \text { Annealing: } & 1 \mathrm{~min} & 67^{\circ} \mathrm{C} \\ \text { Extension: } & 1 \mathrm{~min} & 72^{\circ} \mathrm{C} \\ \text { Denaturierung: } & 0,5 \mathrm{~min} & 96^{\circ} \mathrm{C} \\ \text { Annealing: } & 1 \mathrm{~min} & 62^{\circ} \mathrm{C} \\ \text { Extension: } & 1 \mathrm{~min} & 72^{\circ} \mathrm{C} \\ \text { Finale Extension: } & 5 \mathrm{~min} & 72^{\circ} \mathrm{C}\end{array}\right\} \begin{aligned} & 5 \text { Zyklen, bei jedem } \\ & \begin{array}{l}\text { Zyklus Annealing- } \\ \text { Temperatur } 1{ }^{\circ} \mathrm{C} \text { niedriger }\end{array}\end{aligned} 33$ Zyklen

Zur Kontrolle von Inserts im Vektor pMIR REPORT miRNA Expression Reporter mit dem Primerpaar pMIR diente das PCR-Programm pMIR-Kontroll-PCR.

$\left.\begin{array}{lll}\text { Reaktionsschritt } & \text { Dauer } & \text { Temperatur } \\ \text { Denaturierung/Aktivierung: } & 7 \mathrm{~min} & 96^{\circ} \mathrm{C} \\ \text { Denaturierung: } & 0,5 \mathrm{~min} & 96^{\circ} \mathrm{C} \\ \text { Annealing: } & 1 \mathrm{~min} & 55^{\circ} \mathrm{C} \\ \text { Extension: } & 1 \mathrm{~min} & 72^{\circ} \mathrm{C} \\ \text { finale Extension: } & 5 \mathrm{~min} & 72^{\circ} \mathrm{C}\end{array}\right\} \quad 30$ Zyklen

\subsubsection{Reverse Transkription}

Bei der Reversen Transkription wird RNA als Vorlage genutzt und in cDNA umgeschrieben. Danach kann das cDNA-Fragment mittels PCR amplifiziert werden. Die Kombination dieser 
beiden Schritte wird auch als RT-PCR bezeichnet. Mit Hilfe dieser Methode ist es möglich, auch niedrig-konzentrierte Transkripte eines Gens in verschiedenen Geweben nachzuweisen.

Für die in dieser Arbeit durchgeführten RT-PCR-Analysen wurde unter anderem das Superscript II-Kit der Firma Invitrogen verwendet. Für die Reaktion wurde $1 \mu$ l Oligo(dT) Primer $(10 \mathrm{pmol} / \mu \mathrm{l})$ benutzt. Dieser Primer bindet spezifisch Poly-(A) $)^{+}-\mathrm{mRNA}$. Für die cDNA Synthese wurden $5 \mu \mathrm{g}$ Gesamt-RNA eingesetzt, die mit Ampuwa auf ein Volumen von $11 \mu 1$ verdünnt wurde. Zur RNA wurde $1 \mu \mathrm{d}$ dNTP-Mix hinzugegeben. Nach einer Inkubation des Ansatzes bei $65^{\circ} \mathrm{C}$ für 5 min wurde dieser für 1 min auf Eis gelegt. Nach Zufügen von $4 \mu 15 x$ First Strand-Puffer (Superscript II-Kit) und $2 \mu 1$ 0,1 M DTT folgte eine zweiminütige Inkubation bei $42^{\circ} \mathrm{C}$. Schließlich konnte durch Zugabe von $1 \mu$ l Superscript II-Reverse Transkriptase die Reaktion gestartet werden. Nach 50 min Inkubation bei $42^{\circ} \mathrm{C}$ wurde abschließend bei $70^{\circ} \mathrm{C}$ für $2 \mathrm{~min}$ die Reverse Transkriptase inaktiviert. Die entstandene komplementäre DNA (cDNA) wurde anschließend sofort weiter verwendet oder bei $-20^{\circ} \mathrm{C}$ gelagert.

Mithilfe des Qiagen OneStep RT-PCR-Kits können Reverse Transkription und PCR in einem Schritt durchgeführt werden. Zunächst wurden alle Komponenten auf Eis aufgetaut und gut gemischt. Es wurde ein Master Mix aus 11,5 $\mu 1$ RNase-freiem Wasser, $5 \mu 1$ 5x Qiagen OneStep RT-PCR-Puffer, $1 \mu \mathrm{l}$ dNTP-Mix, 0,75 $\mu 1$ forward-Primer (0,6 $\mu \mathrm{M}$ Endkonzentration), $0,75 \mu 1$ reverse-Primer und $1 \mu$ l Qiagen OneStep RT-PCR Enzyme Mix hergestellt. Dann wurden $5 \mu \mathrm{l}$ RNA hinzugegeben, sodass das Gesamtvolumen pro Reaktionsgefäß $25 \mu 1$ betrug. Die PCR-Reaktionsgefäße wurden auf Eis belassen bis der Cycler $50^{\circ} \mathrm{C}$ erreicht hatte. Im Thermal-Cycler wurde folgendes Programm durchlaufen:

$\left.\begin{array}{lll}\text { Reaktionsschritt } & \text { Dauer } & \text { Temperatur } \\ \text { Reverse Transkription: } & 30 \mathrm{~min} & 50^{\circ} \mathrm{C} \\ \text { Initiale PCR Aktivierung: } & 15 \mathrm{~min} & 95^{\circ} \mathrm{C} \\ \text { Denaturierung: } & 0,5 \mathrm{~min} & 94^{\circ} \mathrm{C} \\ \text { Annealing: } & 1 \mathrm{~min} & 50-68^{\circ} \mathrm{C} \\ \text { Extension: } & 1 \mathrm{~min} & 72^{\circ} \mathrm{C} \\ \text { Finale Extension: } & 10 \mathrm{~min} & 72^{\circ} \mathrm{C}\end{array}\right\} 40$ Zyklen




\subsubsection{Sequenzanalyse}

Für die Sequenzierung von PCR-Produkten nach Sanger et al. (1977) wurde der folgende Ansatz vorbereitet und in Polypropylen-Röhrchen gefüllt.

$\begin{array}{ll}\text { Volumen } & \text { Reagenz } \\ 2-5 \mu 1 & \text { Template-DNA } \\ 1 \mu 1 & \text { Primer } \\ 4 \mu 1 & \text { ET-Mix } \\ \text { auf } 10 \mu 1 & \mathrm{H}_{2} \mathrm{O}\end{array}$

Es wurde pro Reaktionsgefäß nur ein Primer verwendet, entweder sense oder antisense, somit wurden pro DNA-Probe zwei Ansätze benötigt. Es wurde das folgende Programm für die Sequenz-PCR im Thermal-Cycler verwendet.

$\left.\begin{array}{lll}\text { Reaktionsschritt } & \text { Dauer } & \text { Temperatur } \\ \text { Denaturierung/ Aktivierung: } & 3 \mathrm{~min} & 94^{\circ} \mathrm{C} \\ \text { Denaturierung: } & 20 \mathrm{sec} & 94^{\circ} \mathrm{C} \\ \text { Annealing: } & 20 \mathrm{sec} & 60^{\circ} \mathrm{C} \\ \text { Extension: } & 2 \mathrm{~min} & 60^{\circ} \mathrm{C} \\ \text { Finale Extension: } & 5 \mathrm{~min} & 72^{\circ} \mathrm{C}\end{array}\right\} 30$ Zyklen

Im o.g. ET-Mix sind Desoxy- und Didesoxyribonukleotide enthalten. Die vier verschiedenen Didesoxyribonukleotide sind jeweils mit einem Fluoreszenzfarbstoff markiert. Die im ET-Mix enthaltene Polymerase verwendet zufällig Desoxy- und Didesoxy-Nukleotide als Substrat und lagert diese komplementär zum eingesetzten DNA-Strang aneinander. Der Einbau der Didesoxyribonukleotide führt zum Kettenabbruch, da diesen die 3'-Hydroxygruppe fehlt, an die weitere Nukleotide angelagert würden. Nach der PCR werden die Produkte mit $10 \mu 1 \mathrm{H}_{2} \mathrm{O}$ verdünnt und in eine Sephadex-Platte überführt.

Die so entstandenen, verschieden langen DNA Fragmente wurden im Mega BACE 500 Sequencer der Länge nach aufgetrennt. Anschließend wurden die markierten Nukleotide mittels Laser zur Fluoreszenz angeregt. Die Farbsignale wurden detektiert und in ein Chromatogramm umgewandelt, das die Basenfolge der DNA widerspiegelt. Je mehr gleiche Nukleotide gemessen wurden, desto höher war der Peak der einzelnen Base im späteren Ausdruck. 


\subsubsection{Multiplex Ligation-dependent Probe Amplification (MLPA)}

Die MLPA ist eine semi-quantitative Methode, mit der Abweichungen der Kopien-Anzahl bestimmter DNA-Sequenzen im Vergleich zur Wildtyp-Kopienzahl bestimmt werden können. Dazu wird ein Mix aus spezifischen Sonden eingesetzt, die komplementär zur codierenden Sequenz der Exone, aber auch zur 5'- und 3'-UTR sind (Schouten et al. 2002, Sellner et al. 2004).

Es wurde der von Beetz et al. (2008) etablierte Reaktionsansatz Salsa ProMix P213 gemäß Herstellerangaben verwendet. Dazu wurden Patienten-DNA- sowie drei Wildtyp-Proben mit 1x TE-Puffer so verdünnt, dass die eingesetzten 2,5 $\mu$ l DNA-Verdünnung 0,3 $\mu \mathrm{g}$ DNA enthielten. Im PCR-Cycler wurde die DNA 5 min bei $98^{\circ} \mathrm{C}$ denaturiert. Nach Abkühlen auf $25^{\circ} \mathrm{C}$ wurden $0,75 \mu \mathrm{l}$ Salsa ProMix (P213) zugegeben. Dies ist der Reaktionsmix zur Untersuchung des SPG31-Gens auf Deletionen und Duplikationen. Er beinhaltet kurze, markierte DNA-Fragmente. Nach Zugabe von 0,75 $\mu$ l MLPA-Puffer folgten weitere Inkubationsschritte $\left(1 \mathrm{~min}\right.$ bei $95^{\circ} \mathrm{C}, 16 \mathrm{~h}$ bei $\left.60^{\circ} \mathrm{C}\right)$, währenddessen lagerten sich die im Salsa ProMix enthaltenen Sonden an die DNA an. Die Proben wurden auf $54^{\circ} \mathrm{C}$ abgekühlt. Es wurden 1,5 $\mu 1$ Ligase-Puffer A, 1,5 $\mu$ l Ligase-Puffer B, 12,5 $\mu 1$ Ampuwa und 0,5 $\mu 1$ Ligase zugegeben. Es folgten weitere Inkubationsschritte, bei $54^{\circ} \mathrm{C}$ verband die Ligase jeweils zwei in unmittelbarer Nähe zueinander hybridisierte Sonden miteinander $(15 \mathrm{~min})$, bei $98^{\circ} \mathrm{C}$ wurde die Ligase inaktiviert (5 min). Nun wurden die Proben auf $4^{\circ} \mathrm{C}$ abgekühlt. Von dem obigen Produkt wurden $5 \mu 1$ in ein neues Cup überführt und mit $2 \mu$ Salsa PCR-Puffer und $13 \mu 1$ Ampuwa gemischt. Nach Erwärmen des Ansatzes auf $60^{\circ} \mathrm{C}$ wurden $1 \mu \mathrm{l}$ Salsa PCR Primer, $1 \mu 1$ Enzym, 2,75 $\mu 1$ Ampuwa und 0,25 $\mu 1$ Polymerase zugegeben. Es folgte eine PCR. Anschließend wurden die Proben auf $4^{\circ} \mathrm{C}$ abgekühlt.

Jeweils 0,5 $\mu \mathrm{l}$ des PCR-Produkts wurden auf eine 96-Well Platte übertragen. Zu jeder Probe wurden 0,25 $\mu 1 \mathrm{LIZ}$ Size Standard und 9,25 $\mu \mathrm{l}$ HiDi-Formamid pipettiert. Es folgte eine zweiminütige Denaturierung bei $94^{\circ} \mathrm{C}$, danach wurde die Platte kurz auf Eis gestellt. Nach Abzentrifugieren der Proben folgte die Auswertung im Genetic Analyzer 3130. Die Ergebnisse wurden mit dem Programm Gene Marker (Softgenetics) ausgewertet, welches die Menge der entstandenen PCR-Produkte in Form von Peaks darstellt. Die Peaks der Patientenprobe werden mit denen der Wildtypproben ins Verhältnis gesetzt. Ergeben sich Quotienten zwischen 0,7 und 1,2 ist anzunehmen, dass keine größeren Deletionen oder Duplikationen vorliegen. Ergibt sich ein Quotient größer als 1,2 ist dies als Hinweis auf eine Duplikation zu werten, ist er kleiner als 0,7 ist von einer Deletion auszugehen. Bei auffälligen 
Ergebnissen wurde das Verfahren wiederholt.

\subsubsection{Auftrennung von DNA-Fragmenten mittels Agarosegel-Elektrophorese}

Zur Auftrennung von PCR-Produkten oder Isolierung von bestimmten DNA-Fragmenten wurden Gele mit 1-2\% (w/v) Agarose verwendet. Je nach Größe der Gellaufkammer wurde das Agarose-Pulver mit 50-150 ml 0,5 x TBE-Puffer versetzt und in einem Erlenmeyerkolben solange erhitzt, bis die Agarose vollständig gelöst war. Nach Abkühlen auf ca. $50-70^{\circ} \mathrm{C}$ wurde Ethidiumbromid in einer Endkonzentration von $0,5 \mu \mathrm{g} / \mathrm{ml}$ zugesetzt und der gesamte Ansatz in eine Horizontalkammer gegeben. Nach Aushärten des Gels wurde die Kammer mit 0,5 x TBE-Laufpuffer aufgefüllt.

Zum Auftrennen wurde die DNA zunächst mit Stoppmix gemischt und dann in kleine Taschen im Gel überführt. Es wurde für 15-45 min eine konstante Spannung von 85-125 V angelegt. Im elektrischen Feld laufen die geladenen DNA-Fragmente je nach Länge unterschiedlich schnell im Gel: Kurze Fragmente laufen schneller als längere. Zur Längenbestimmung liefen Längenstandards von 100 bp- oder 1 kb-Länge mit.

Die Analyse und fotografische Dokumentation erfolgte mithilfe eines UV-Transilluminators. Das Ethidiumbromid interkaliert in die DNA und wird durch das UV-Licht zur Fluoreszenz angeregt. So werden je nach Länge der DNA-Fragmente unterschiedliche Banden im Gel sichtbar.

\subsubsection{Aufreinigung von PCR-Produkten}

\subsubsection{Invisorb MSB Spin PCRaspace}

Mithilfe von Invisorb MSB Spin PCRaspace-Röhrchen (Invitrogen) wurden DNA-Fragmente von überschüssigen Salzen, dNTPs und Primern aus der PCR-Reaktion getrennt. Dazu wurde das PCR-Produkt zunächst mit $250 \mu 1$ Binding-Puffer vermischt und in eine Filtersäule überführt. Bei der Zentrifugation (13400 x g, RT, 3 min) blieb die DNA an der Filtermembran gebunden. Der Durchfluss wurde verworfen. Anschließend wurden 10-20 $\mu$ l Elution-Puffer oder Ampuwa auf die Membran gegeben und 1 min bei RT inkubiert. Bei der Zentrifugation (9300 x g, RT, 1 min) löste sich die DNA aus der Membran und wurde im Sammelröhrchen aufgefangen. 


\subsubsection{Nucleofast Platte}

Bei größerer Anzahl aufzureinigender Proben wurden 96-Well-Nucleofast-Platten (Clontech) verwendet. Diese wurden zunächst mit Wasser gespült. Anschließend wurden in jede Vertiefung $100 \mu \mathrm{l}$ Ampuwa pipettiert, die PCR-Produkte wurden ebenfalls mit $100 \mu 1$ Ampuwa vermischt und auf die Platte übertragen. Nach der Zentrifugation (1000 x g, RT, $15 \mathrm{~min}$ ), wurden erneut $100 \mu \mathrm{l}$ Ampuwa in die Vertiefungen gegeben und die Platte wurde erneut zentrifugiert. Schließlich konnte die DNA mithilfe von $30 \mu$ Ampuwa aus der Membran der Aufreinigungsplatte gelöst werden und zur weiteren Verwendung in Reaktionsgefäße überführt werden.

\subsubsection{Isolation von DNA-Fragmenten aus Agarose-Gelen}

Nach einer Gelelektrophorese (vgl. 2.2.8) wurden die unter UV-Licht sichtbaren Banden mit einer sterilen Skalpellklinge ausgeschnitten. Die Gel-Würfel wurden in ein Eppendorf-Cup überführt und gewogen. Die Aufreinigung erfolgte nach Herstellerangaben mit dem Wizard SV Gel and PCR Clean-Up-System. Pro $100 \mathrm{mg}$ Gel wurden $100 \mu 1$ Membrane Binding Solution in ein Eppendorf-Cup gegeben und mit einem Vortex gemischt. Es folgte eine kurze Zentrifugation (13000 x g, RT, wenige Sekunden).

Während einer 10 -minütigen Inkubation bei $57^{\circ} \mathrm{C}$ löste sich das Agarosegel komplett auf. Der Inhalt des Reaktionsgefäßes wurde in eine Filtersäule überführt und zentrifugiert (13000 x g, RT, 1 min). Die DNA wurde in Anwesenheit von chaotropen Salzen spezifisch an SilicagelPartikel gebunden. Der Durchfluss wurde verworfen. Anschließend wurden $700 \mu 1$ Membrane Wash Solution auf die Säule gegeben und erneut zentrifugiert (13000 x g, RT, 1 min). Der Durchfluss wurde verworfen. Es wurde ein weiterer Waschschritt mit $500 \mu 1$ Membrane Wash Solution durchgeführt. Die Zentrifugation erfolgte in zwei Schritten (13000 x g, RT, 3 min; $13000 \times \mathrm{g}, \mathrm{RT}, 2 \mathrm{~min})$. Um sicherzustellen, dass die Membran trocken war, wurde der Durchfluss zwischenzeitlich verworfen. Die Filtersäule wurde in ein 1,5 ml-Cup überführt, dann wurden $25 \mu \mathrm{l}$ Ampuwa auf die Membran gegeben. Nach 2 min Inkubation bei $60^{\circ} \mathrm{C}$, wurde die DNA mittels Zentrifugation (13000 xg, RT, $1 \mathrm{~min})$ in das Sammelröhrchen überführt. 


\subsubsection{Modifikation von Nukleinsäuren}

\subsubsection{DNA-Spaltung mittels Restriktionsendonukleasen}

Restriktionsendonukleasen sind Enzyme, die DNA-Fragmente im Bereich sog. pallindromischer Sequenzen schneiden können. Pallindromische Sequenzen sind DNAAbschnitte, die am sense-Strang wie auch am antisense-Strang jeweils in $5^{\prime} \rightarrow 3^{\prime}$-Richtung gelesen die gleiche Basenfolge aufweisen. Mithilfe dieser Enzyme können u.a. Inserts aus Vektoren entfernt werden.

Für den Restriktionsverdau wurden pro $\mu$ g Plasmid-DNA 2-3 U des Enzyms eingesetzt und mit dem entsprechenden Puffer und Ampuwa auf ein Gesamtvolumen von $30 \mu 1$ aufgefüllt. Bei simultaner Spaltung mit zwei Restriktionsendonukleasen wurde der Puffer eingesetzt, der für beide Enzyme ausreichende Aktivität erlaubt (vgl. Herstellerangaben). Der Ansatz wurde $1 \mathrm{~h}$ bei $37^{\circ} \mathrm{C}$ inkubiert.

\subsubsection{Ligation von DNA-Fragmenten}

Mithilfe einer Ligase können DNA-Fragmente verbunden werden. Im Rahmen dieser Arbeit wurde dieses Verfahren dazu verwendet, DNA-Fragmente in eine sog. Multi Cloning Site (MCS) von Vektoren (ringförmige Bakterien-DNA-Fragmente) zu integrieren (Clark, 1988; $\mathrm{Hu}, 1993)$. Dazu wurden 30-120 ng Insert-DNA mit 25-50 ng Vektor-DNA, $1 \mu 1$ T4 DNA Ligase und $5 \mu 12 \times$ T4-Puffer vermischt und $2 \mathrm{~h}$ bei RT oder über Nacht bei $4{ }^{\circ} \mathrm{C}$ inkubiert.

\subsubsection{Zielgerichtete Mutagenese}

Hutchison et al. berichteten 1978 erstmals von der Möglichkeit, mithilfe von Oligonukleotiden gezielt DNA-Sequenzen zu modifizieren. Dazu wird die zu verändernde doppelsträngige DNA-Sequenz zunächst in ein dam+Plasmid integriert. Es werden Oligonukleotide erstellt, die die gewünschte Mutation enthalten und ansonsten komplementär zur DNA-Matrize (Insert im Vektor) sind. Diese werden für eine PCR eingesetzt, in der das Plasmid-Konstrukt amplifiziert wird.

Für die PCR wurden die folgenden Komponenten des QuikChange Site-Directed Mutagenesis-Kits eingesetzt. 


$\begin{array}{ll}\text { Volumen } & \text { Reagenz } \\ 5 \mu \mathrm{l} & \text { 10x Reaction Buffer } \\ 5-50 \mathrm{ng} & \text { Doppelsträngige Template-DNA } \\ 125 \mathrm{ng} & \text { forward-Primer } \\ 125 \mathrm{ng} & \text { reverse-Primer } \\ 1 \mu \mathrm{l} & \text { dNTP-Mix } \\ 1 \mu \mathrm{l} & \text { PfuTurbo DNA Polymerase }(2.5 \mathrm{U} / \mu \mathrm{l})\end{array}$

Der Ansatz wurde für eine PCR unter folgenden Bedingungen eingesetzt.

$\left.\begin{array}{lll}\text { Reaktionsschritt } & \text { Dauer } & \text { Temperatur } \\ \text { Denaturierung/Aktivierung: } & 0,5 \mathrm{~min} & 95^{\circ} \mathrm{C} \\ \text { Denaturierung: } & 0,5 \mathrm{~min} & 95^{\circ} \mathrm{C} \\ \text { Annealing: } & 1 \mathrm{~min} & 55^{\circ} \mathrm{C} \\ \text { Extension: } & 7 \mathrm{~min} & 68^{\circ} \mathrm{C}\end{array}\right\} \quad 20$ Zyklen

Das synthetische Konstrukt enthält, im Gegensatz zum Ursprungskonstrukt, keine Methylgruppen. Diese Tatsache macht man sich zunutze und verdaut das PCR-Produkt mit dem Restriktionsenzym DpnI (Zielsequenz: 5'- Gm6ATC -3'). DpnI ist eine Endonuklease, die spezifisch methylierte und hemimethylierte DNA-Sequenzen spaltet (Lacks und Greenberg 1975 und 1977). Es werden also lediglich die methylierten Ursprungsvektoren verdaut. Für den Verdau wurde dem PCR-Produkt $1 \mu \mathrm{L} p n \mathrm{I}(10 \mathrm{U} / \mu \mathrm{l})$ zugesetzt und die Probe für $1 \mathrm{~h}$ bei $37^{\circ} \mathrm{C}$ inkubiert.

Nach Aufreinigung der mutierten Vektoren wurde das Konstrukt in kompetente E. coli DH5 $\alpha-$ Zellen transformiert, welche in LB-Medium vermehrt wurden. In einer Mini-Präparation wurde das Plasmid aufgereinigt und konnte anschließend für weitere Versuche eingesetzt werden.

\subsubsection{Transformation kompetenter Zellen mit Plasmid-DNA}

Wird ein verändertes Plasmid in kompetente Zellen eingebracht, nennt man dies Transformation (Hanahan 1983; Ausubel et al. 1994). Dazu wurden DH5 $\alpha$-Zellen auf Eis aufgetaut und mit einem Ligations-Ansatz (vgl. 2.2.11.2) für 30 min auf Eis inkubiert. Es folgte ein Hitzeschock für $35 \mathrm{sec}$ bei $37^{\circ} \mathrm{C}$, wodurch sich „Poren“ in der Bakterienmembran öffneten, durch die die DNA in die Zellen gelangen konnte. Anschließend wurden die Proben 
für 5 min auf Eis gelegt. Nach Zugabe von $200 \mu$ S.O.C.-Medium (Invitrogen) wurden die Bakterien für $1 \mathrm{~h}$ bei $37^{\circ} \mathrm{C}$ unter ständigem Schwenken bebrütet. Bei Verwendung des $p G E M$ T Easy-Vektors wurden $120 \mu \mathrm{l}$ des Ansatzes auf IPTG/x-Gal-LB-Agar gegeben. Bei der Verwendung anderer Vektoren wurden einfache LB-Agar-Platten verwendet. Es folgte eine Inkubation bei $37^{\circ} \mathrm{C}$ für $6-8 \mathrm{~h}$.

Auf den verwendeten Platten konnten nur Bakterien wachsen, die den Vektor aufgenommen haben, da auf diesem die Resistenz gegen das Antibiotikum Ampicillin codiert ist.

Im Falle des IPTG/ x-Gal-LB-Agars gibt es als zusätzliche Kontrolle die Möglichkeit der blau-weiß-Selektion. Wird das gewünschte DNA-Fragment während der Ligation nicht in den Vektor integriert, exprimieren die Bakterien durch IPTG-Zusatz das Enzym $\beta$-Galaktosidase. Das im Kulturmedium enthaltene $\mathrm{x}$-Gal ist ein künstliches Substrat für die $\beta$-Galaktosidase. Durch Spaltung von x-Gal entsteht ein blauer Farbstoff, der in den Bakterien ausfällt und die Kolonien blau anfärbt. Es wurden für die weiteren Versuche also nur ungefärbte Kolonien gewählt.

\subsubsection{Kultur in LB-Medium}

Nach Inkubation der Bakterien auf Agar-Platten, wurden einzelne Kolonien mit autoklavierten Holzstäbchen oder Pipettenspitzen in sterile Reagenzgläser mit 2,5 ml LB-Medium und 2,5 $\mu 1$ Ampicillin überführt. Es folgte eine Inkubation für $8-12 \mathrm{~h}$ bei $37^{\circ} \mathrm{C}$ im Rüttelinkubator.

\subsubsection{Glycerin-Stocks}

$500 \mu \mathrm{l}$ einer LB-Übernacht-Kultur wurden für die Herstellung von Glycerin-Stocks verwendet. Dazu wurden der Kultur $500 \mu 1$ steriles Glycerin zugesetzt. Bei $-80^{\circ} \mathrm{C}$ können die Stocks dauerhaft gelagert werden.

\subsubsection{Kultur eukaryotischer Zellen}

Die zellbiologischen Versuche wurden an der adhärenten murinen Fibroblastenzelllinie NIH3T3 (ATCC, Rockville, USA) durchgeführt. Alle Arbeiten wurden an einer Zellkulturbank mit steriler Laminarströmung durchgeführt. Die Zellen wurden in einem Brutschrank bei $37^{\circ} \mathrm{C}$ und unter $5 \% \mathrm{CO}_{2}$-Begasung kultiviert. Das NIH3T3-Medium wurde 
vor Gebrauch in einem Wasserbad auf $37^{\circ} \mathrm{C}$ erwärmt. Alle drei Tage wurden die Zellen umgesetzt und gegebenenfalls expandiert. Dazu wurde zunächst das Nährmedium entfernt, anschließend wurden die Zellen zwei Mal mit $10 \mathrm{ml}$ DPBS gewaschen und mithilfe von $5 \mathrm{ml}$ Trypsin vom Boden der Kulturflasche gelöst. Nach 5 min Inkubation bei $37^{\circ} \mathrm{C}$ wurde das Trypsin mit $5 \mathrm{ml} \mathrm{FKS-haltigem} \mathrm{Medium} \mathrm{inaktiviert.} \mathrm{Die} \mathrm{Zellen} \mathrm{wurden} \mathrm{in} \mathrm{Zentrifugen-}$ Röhrchen überführt und abzentrifugiert (750 x g, RT, 5 min), der Überstand wurde verworfen. Die so gewonnenen Zellen wurden in $10 \mathrm{ml}$ frischem Nährmedium aufgenommen. Die Zellkonzentration wurde mithilfe einer Neubauer-Zählkammer ermittelt. Die Zellen wurden in Konzentrationen zwischen $2-3 \times 10^{5} / \mathrm{ml}$ auf 12-Well-Kulturplatten ausgesät. Wurde eine Zelldichte von $70-80 \%$ erreicht, konnte eine Transfektion durchgeführt werden.

\subsubsection{Transiente Transfektion eukaryotischer Zellen}

Unter einer Transfektion versteht man das Einbringen von Fremd-DNA in eukaryote Zellen. Für die Transfektion der 3T3-Zellen wurde Attractene Transfection Reagent nach Herstellerangaben eingesetzt. Dieses nicht-liposomale Reagenz bildet Mizellen um die einzubringende DNA, welche mit der Zellmembran der kultivierten Zellen fusionieren. Die Fremd-DNA wird lediglich in das Zytoplasma geschleust und nicht in das eigentliche Zellgenom integriert.

Die Zellen wurden mit dem miRNA Expression Reporter sowie mit dem $\beta$-Gal Control-Vektor cotransfiziert. $\quad \beta$-Gal sollte später zur Normalisierung bei unterschiedlicher Transfektionseffizienz zwischen den einzelnen Proben verwendet werden. Der miRNA Expression Reporter enthält ein Gen für das Enzym Luciferase. Die Expression dieses Enzyms kann durch Integration einer 3'UTR-Sequenz in den Vektor und Zugabe einer in diesem Bereich bindenden miRNA reguliert werden. Es wurden drei verschiedene miRNA Expression Reporter-Konstrukte verwendet. Der erste Vektor enthielt eine mutierte 3'UTR, der zweite enthielt die Wildtyp-3'UTR und im dritten Fall wurde ein unveränderter Vektor eingesetzt.

Für einen $60 \mu \mathrm{l}$-Transfektionsansatz wurden 0,4 $\mu \mathrm{g}$ miRNA Expression Reporter, 0,4 $\mu \mathrm{g} \beta$-Gal Control-Vektor und 1,5 $\mu 1$ Attractene Transfection Reagent sowie die miR-691 in einer Endkonzentration von $50 \mathrm{nM}$ eingesetzt. Dieser Ansatz wurde für $10 \mathrm{~min}$ bei RT unter gelegentlichem Schwenken inkubiert. Währenddessen wurden die zu transfizierenden Zellen mit $0,5 \mathrm{ml}$ DPBS gewaschen. In jedes Well wurden $60 \mu \mathrm{l}$ Transfektions-Mastermix und $500 \mu 1$ 
Medium gegeben. Nach leichtem Schwenken wurden die Zellen bei $37^{\circ} \mathrm{C}$ für $24 \mathrm{~h}$ bebrütet. Für jeden der drei Ansätze wurden drei technische Replikate angelegt.

\subsubsection{Lysieren eukaryotischer Zellen}

Nach $24 \mathrm{~h}$ Bebrütung wurden die Zellen mit $0,5 \mathrm{ml}$ DPBS gewaschen und nach Herstellerangaben mit $100 \mu 1$ verdünntem Cell Culture Lysis Reagent überschichtet. Die Platten wurden mit Parafilm verschlossen und bei $-80^{\circ} \mathrm{C}$ eingefroren. Nach $24 \mathrm{~h}$ konnten die Platten wieder aufgetaut werden und die Proben konnten nach sorgfältigem Lösen der Zellen vom Plattenboden in Eppendorf-Reaktionsgefäße überführt werden. Die Proben wurden erneut bei $-80^{\circ} \mathrm{C}$ tiefgefroren oder sofort zur Messung eingesetzt.

\subsubsection{Lumineszenz-Messungen}

\subsubsection{Messung der Luciferase-Aktivität}

Für die Messung der Luciferase-Aktivität wurden je Probe zwei Wells auf der Messplatte mit $20 \mu 1$ des Lysats gefüllt. Die Schläuche der Injektionsvorrichtung am Luminometer wurden mit 70\%-Ethanol und Wasser gespült und anschließend mit den später zu injizierenden Reagenzien gefüllt. Zunächst wurde die Hintergrund-Aktivität der Proben gemessen, dann pipettierte das Luminometer $100 \mu 1$ Luciferase-Reagenz zu jeder Probe. In diesem Reagenz sind alle Substrate enthalten, um dem Enzym Luciferase optimale Reaktionsbedingungen zu schaffen (u.a. ATP, $\mathrm{Mg}^{2+}$ ). Es kam zur Lichtemission, die nach einer Latenz von 2 sec luminometrisch gemessen wurde. Vom gemessenen Wert wurde jeweils der vorher bestimmte Hintergrund-Wert subtrahiert.

\subsubsection{Messung der ß-Galactosidase-Aktivität}

Für die $\beta$-Gal-Messung wurden je Probe zwei Wells mit $10 \mu 1$ Lysat gefüllt. Nach Spülen und Füllen der Pipettiervorrichtung wurden in jedes Well zusätzlich $70 \mu 1$ Puffer und 0,7 $\mu 1$ Galacton gegeben. Nach $14 \mathrm{sec}$ Inkubation wurde die Hintergrundaktivität gemessen. Eine Stunde später wurden $100 \mu 1$ Accelerator in jedes Well pipettiert und mit $5 \mathrm{sec}$ Latenz wurde die Lumineszenz bestimmt. Der erste Messwert wurde vom Zweiten subtrahiert. 


\subsubsection{Auswertung der Lumineszenz-Messergebnisse}

Die Auswertung erfolgte mit einem Tabellenkalkulationsprogramm. Um Schwankungen der Transfektionseffizienz der verschiedenen Ansätze bei der Auswertung zu berücksichtigen, wurden die Luciferase-Messwerte jeder einzelnen Probe gegen die jeweiligen $\beta$-Gal-Werte normalisiert. Dies setzt voraus, dass die Kotransfektion von $\beta-G a l$ und $p M I R$ REPORT in gleicher Konzentration bzw. mit gleicher Effizienz erfolgte. Pro Ansatz (z.B. WT-Probe) wurden sechs Messwerte gewonnen, aus denen jeweils der Mittelwert und die sich ergebende Standardabweichung berechnet wurden.

Um zu sehen, welchen Einfluss die Mutation im Bereich der miR-Bindestelle auf die Luciferase-Expression hat, wurde der Messmittelwert der Wildtyp-Proben als 1 angenommen und alle anderen Messmittelwerte durch diesen dividiert. Nach Berechnung der Standardabweichungen erfolgte eine grafische Darstellung in Form von Säulendiagrammen. 


\section{Ergebnisse}

\subsection{Patientenstudien}

\subsubsection{Spektrum und Inzidenz von SPG31-Mutationen}

Das Ziel der Studie war die Bestimmung der Inzidenz von Mutationen im SPG31-Gen bei den deutschen Familien des HSP-Patientenkollektivs des Instituts für Humangenetik Göttingen.

Es wurden Patienten in die Studie eingeschlossen, bei denen eine unkomplizierte HSP klinisch diagnostiziert wurde. Bei positiver Familienanamnese, die mit einem autosomal dominanten Erbgang vereinbar ist, sollten bereits Mutationen in SPG3A und SPG4 ausgeschlossen worden sein. Es konnten 64 Patienten in die Studie aufgenommen werden.

\subsubsection{Ergebnisse der SPG31-Sequenzierung}

Tab. 4: Übersicht über die Ergebnisse der Sequenzanalyse.

\begin{tabular}{|c|c|c|c|}
\hline & untersuchte Patienten & unauffällig & mutiert \\
\hline insgesamt & 64 & 62 & 2 \\
\hline weiblich & 36 & 35 & 1 \\
\hline männlich & 28 & 27 & 1 \\
\hline
\end{tabular}

Nach Isolierung der Patienten-DNA aus Leukozyten, Vervielfältigung der DNA-Abschnitte von Interesse mittels PCR und nach anschließender Aufreinigung der Produkte wurde eine Sequenzierung der sieben SPG31-Exons inklusive flankierender Regionen durchgeführt. Die Tabelle 4 zeigt eine Zusammenfassung der Ergebnisse. Bei der Sequenzierung konnten bei zwei Patienten insgesamt drei genetische Veränderungen nachgewiesen werden. Das ergibt eine Mutationsrate von ca. 3,13\%. 


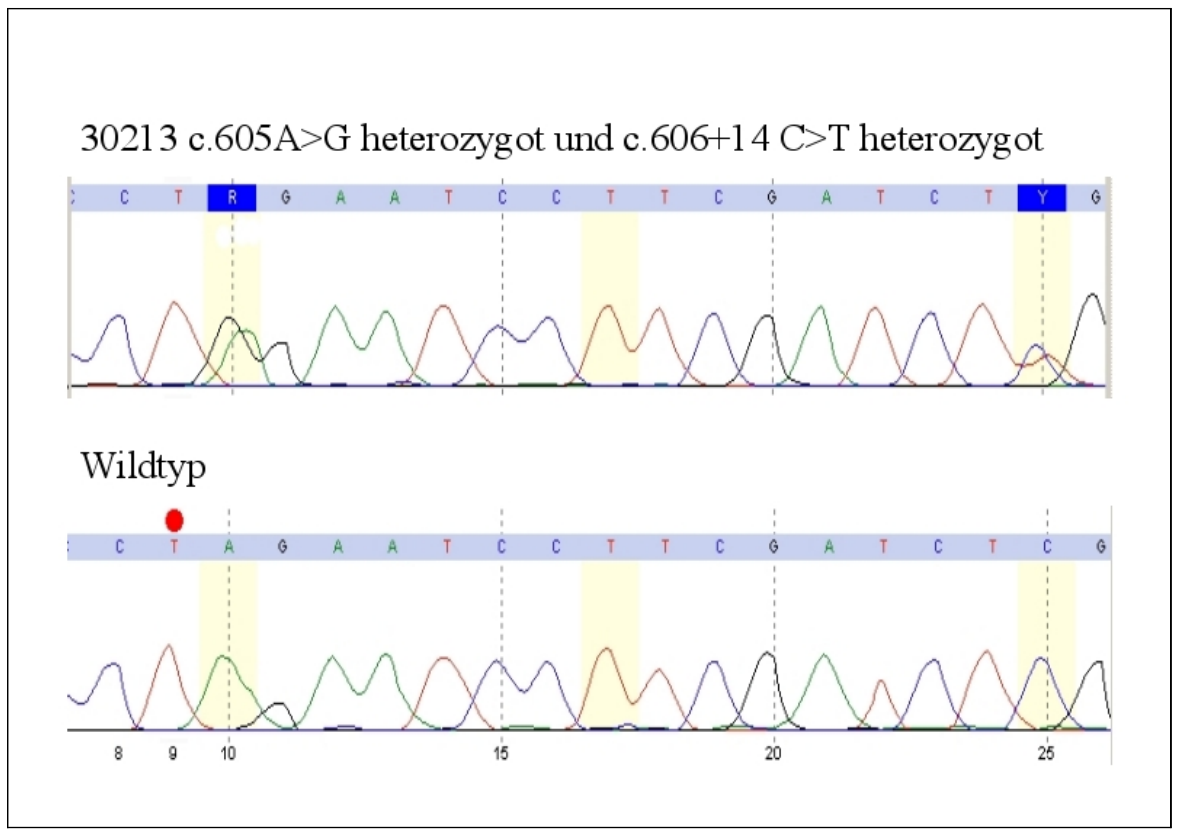

Abb. 4: Auszug aus der Sequenz des SPG31-Exons 7 des Indexpatienten 30213.

Die Mutation c.605A>G (p.X202WfsX256) wird durch ein dunkelblau hinterlegtes " $R$ “ markiert, welches für das heterozygote Vorliegen der Basen A und G steht. Der rote Punkt markiert das in der Wildtypsequenz an dieser Stelle liegende Stopp-Codon TAG. Die mit dunkelblau hervorgebobene Mutation „Y“ $Y^{\prime}($ c.606+14C>T) liegt im sog. 3'-untranslatierten Bereich (3'UTR). Das Y zeigt das jeweils heterozygote Vorliegen der Basen $C$ und T an.

Bei dem Indexpatienten 30213 konnte die bislang nicht beschriebene heterozygote Mutation c.605 A>G (p.X202WfsX256) nachgewiesen werden. Diese Mutation betrifft das StoppCodon „TAG“ im Exon 7 des SPG31-Gens, das entstandene Triplet „TGG“ codiert für die Aminosäure Tryptophan. Es kommt zur Verlängerung der Proteinsequenz, das neue StoppCodon (X) liegt auf Proteinebene an Position 256. Die zweite bei diesem Patienten vorliegende Mutation c.606+14C $>$ T liegt im 3'-untranslatierten Bereich (3'UTR) des SPG31Gens. Diese Veränderung wurde bereits bei einem HSP-Patienten beschrieben und als krankheitsverursachend angenommen (Beetz et al. 2008). Die Abbildung 4 zeigt den veränderten Abschnitt der SPG31-Sequenz bei dem Indexpatienten 30213.

Um herauszufinden, ob beide Mutationen auf einem Allel liegen, wurde das PCR-Produkt von Exon 7 in den Vektor $p G E M-T$ Easy (Vektorkarte s. Abb. 5) kloniert und in DH5 $\alpha$-Zellen vermehrt. Es wird davon ausgegangen, dass pro Zellkolonie nur ein Vektor vorliegt, in den entweder das maternale oder das paternale Allel integriert wurde. Die anschließende Sequenzierung von 10 Klonen mithilfe der Primer T7 und SP6 zeigte, dass beide Mutationen auf einem Allel (d.h. in cis) liegen und somit miteinander vererbt werden (vgl. Abb. 6). 


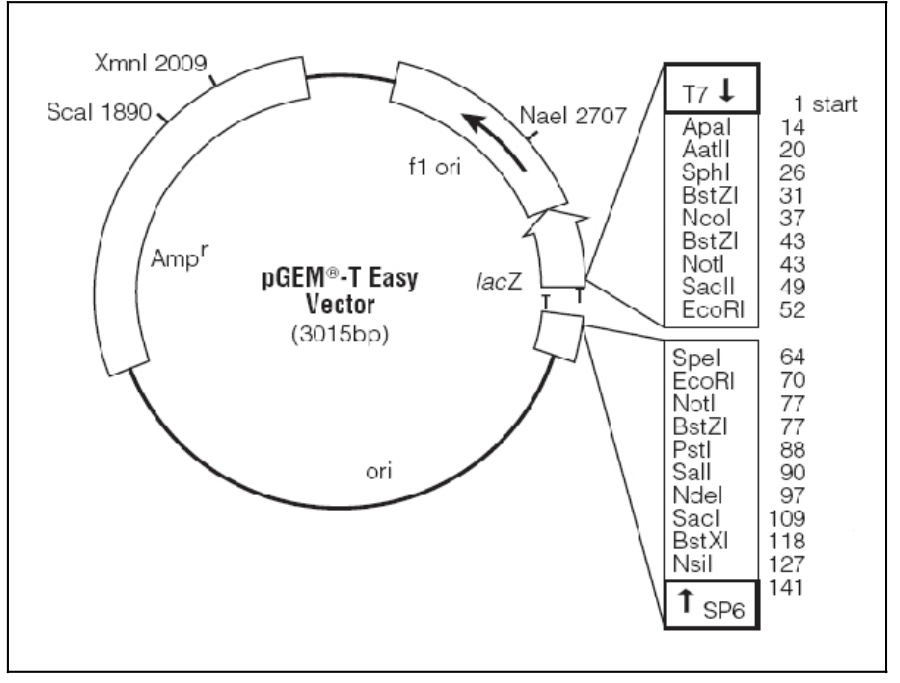

Abb. 5: pGEM-T Easy-Vektorkarte.

Zwischen den Bindestellen der Standardprimer SP6 und T7 liegen Angriffspunkte verschiedener Restriktionsendonukleasen. Dort kann nach entsprechendem Restriktionsverdau eine beliebige Nucleotidsequenz mithilfe einer Ligase eingefügt werden.

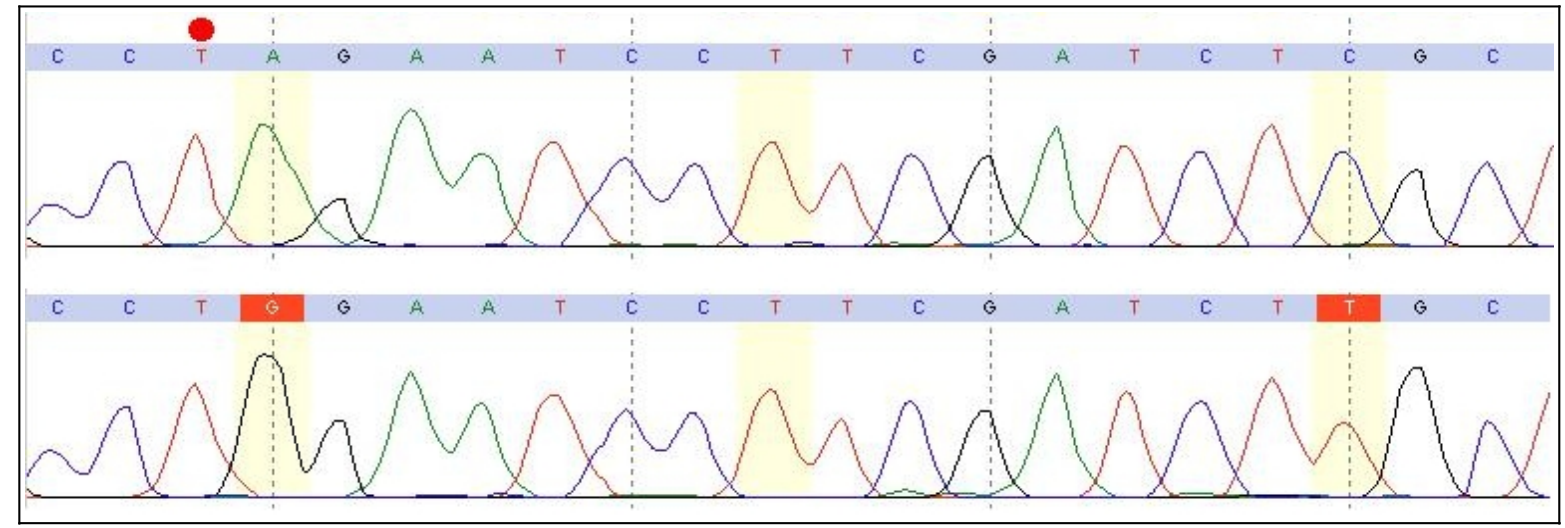

Abb. 6: Ausschnitt der Sequenzen des in pGEM-T Easy klonierten Exons 7.

Oben: Wildtyp-Allel, unten: Allel mit den beiden Mutationen c.605 A>G und c.606+14C>T (rot hinterlegte Buchstaben). Der rote Punkt markiert das Stopp-Codon in der Wildtypsequenz (oben)

Bei der Indexpatientin 28103 wurde die bereits von Züchner et al. (2006) beschriebene heterozygote Splice-Site-Mutation c.183-2A>G nachgewiesen. Die Abbildung 7 zeigt den Ausschnitt aus der SPG31-Sequenz der Patientin, in dem die Mutation liegt. 


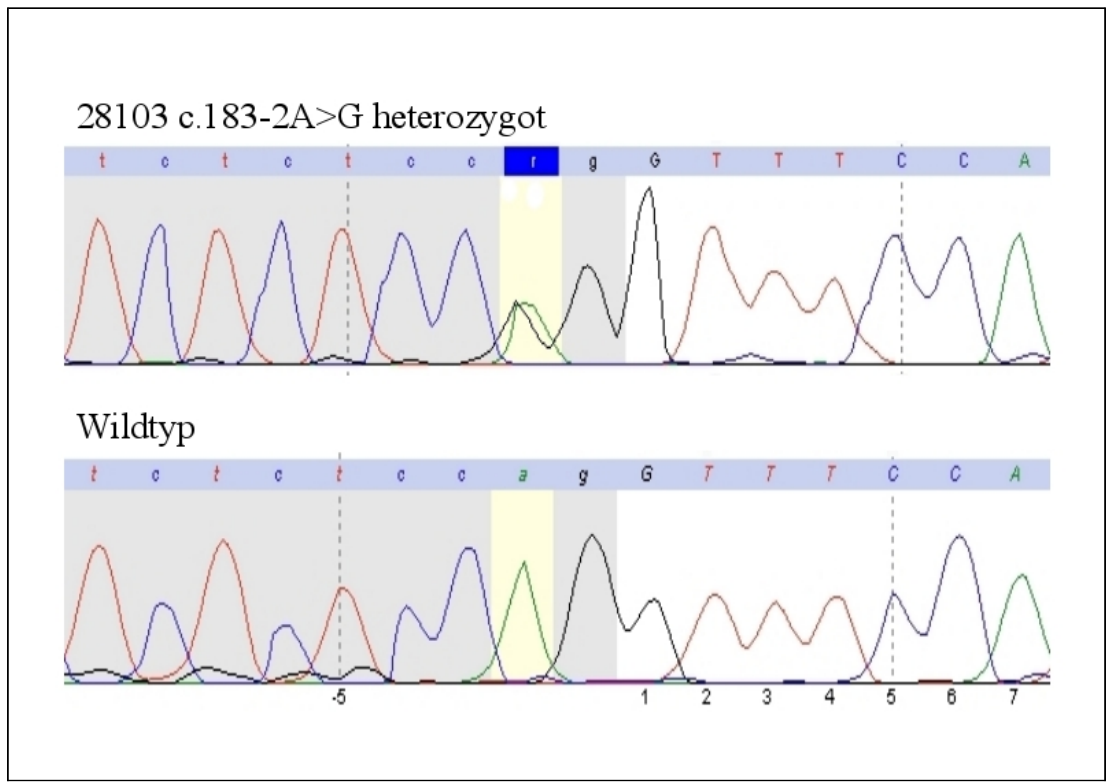

Abb. 7: Auszug aus der Sequenz des SPG31-Exons 4 von 28103.

Mutation c.183-2A>G: Bei dieser Patientin zeigte die Sequenzierung die mit einem dunkelblau hinterlegten „r" markierte Mutation, die sich auf die 5'-Splice-Site des Introns 4 auswirkt. Das dunkelblau hinterlegte ,r" zeigt das heterozygote Vorliegen der Basen A und G an.

Die Tabelle 5 zeigt eine Übersicht über die gefundenen Mutationen mit zugehöriger Literaturangabe, in der diese bereits beschrieben wurden.

Tab. 5: Übersicht über die gefundenen Mutationen.

\begin{tabular}{|c|l|c|l|l|}
\hline \multirow{2}{*}{ Patient } & \multicolumn{2}{|l|}{ Veränderung auf } & Art der Mutation & \multirow{2}{*}{ Literaturhinweis } \\
\cline { 2 - 5 } & \multicolumn{1}{|c|}{ DNA-Ebene } & Protein-Ebene & & bisher nicht beschrieben \\
\hline \multirow{2}{*}{30213} & c.605 A $>$ G & p.X202WfsX256 & Stopp-Codon-Disruption & Beetz et al., 2008 \\
\cline { 2 - 5 } & c.606 $+14 \mathrm{C}>\mathrm{T}$ & - & Veränderung einer miRNA-Bindestelle & Züchner et al., 2006 \\
\hline
\end{tabular}

\subsubsection{Detektion von Deletionen/ Duplikationen mittels „Multiplex Ligation- dependent Probe Amplification" (MLPA)}

Beetz et al. beschrieben 2008 eine große Duplikation im SPG31-Gen als krankheitsverursachende genetische Veränderung. Die Duplikation beginnt im 1. Intron und reicht weit über Exon 7 hinaus.

Nach Ausschluss von Punktmutationen, kleineren Deletionen oder Duplikationen mittels Sequenzierung (s. 3.1.1.1), wurden die DNA-Proben der Patienten für eine MLPAUntersuchung eingesetzt. Bei 42 von 62 sequenzierten Patientenproben war eine ausreichchende DNA-Menge vorhanden, um diese Analyse durchführen zu können. Es 
konnten jedoch keine großen Rearrangements nachgewiesen werden. Dies zeigt auch die Zusammenfassung in Tabelle 6.

Tab. 6: Übersicht über die Ergebnisse der MLPA-Analyse.

\begin{tabular}{|c|c|c|c|}
\hline MLPA Analysen & unauffällig & Deletionen & Duplikationen \\
\hline 42 & 42 & 0 & 0 \\
\hline
\end{tabular}

\subsubsection{Charakterisierung der betroffenen Familien}

\subsubsection{Charakterisierung des Indexpatienten 30213 und seiner Familie}

Der Patient 30213 ist mittlerweile 54 Jahre alt. Seit seinem 26. Lebensjahr leidet er an einer langsam progredienten Spastik der unteren Extremitäten sowie Fußdeformitäten. Zusätzlich klagte er über spastikartige Rückenschmerzen, die nach erfolgter Nervendurchtrennung nicht mehr aufgetreten sein sollen. Durch die Spastik ist sein Gangbild unsicher. Die Füße sind beim Gehen nach innen rotiert und die Knie neigen zur Valgus-Stellung. Laufen ist nur noch unter Zuhilfenahme eines Rollators möglich.

Die Abbildung 8 zeigt den Stammbaum des Indexpatienten 30213 (III4). Die Vererbung der Erkrankung erfolgt autosomal dominant. In jeder Generation gibt es Erkrankte und es sind sowohl Frauen als auch Männer betroffen.

Der Indexpatient hat eine 23 Jahre alte betroffene Tochter (IV1), die seit der Geburt an Sichelfüßen leidet. Im Alter von 13 Monaten begann sie zu laufen. Dabei fiel auf, dass sie überwiegend auf den Zehenspitzen ging, sodass hier der Erkrankungsbeginn gesehen wird. Ab dem 7. Lebensjahr sei das Gangbild auffälliger geworden. Zeitweise wurde das linke Bein nachgezogen und es konnte eine lumbale Hyperlordose beobachtet werden. Weiterhin bestand eine Spastik im Bereich der Füße, wobei der Muskeltonus und das Reflexniveau im Bereich von Ober- und Unterschenkel unauffällig waren. Der Fersengang war beidseits nicht möglich. Eine molekulargenetische Untersuchung ist bislang nicht erfolgt. 


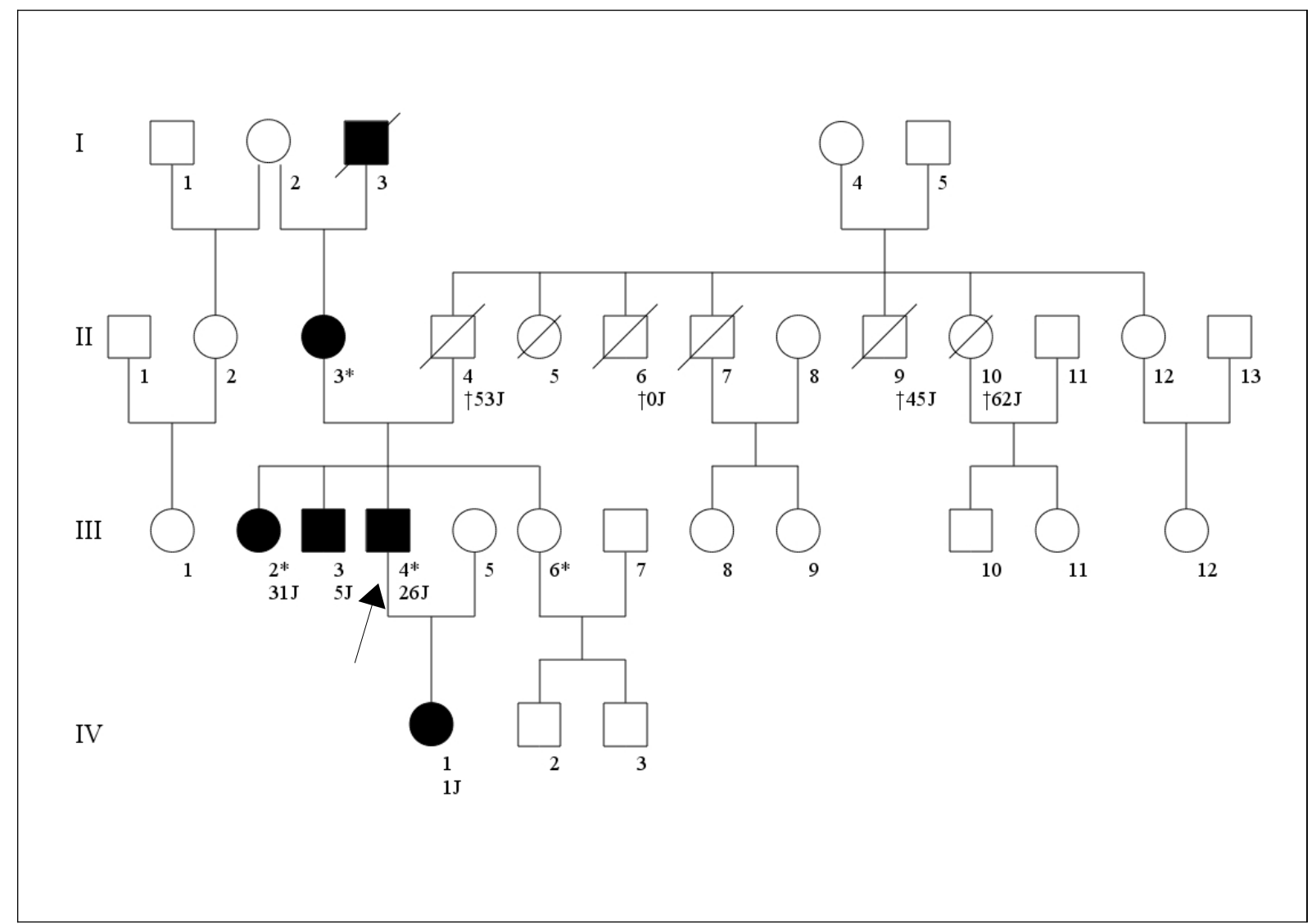

Abb. 8: Stammbaum des Patienten 30213 (III4).

Soweit bekannt, ist das Erkrankungsalter (z.B.1J bei Person IVI) bzw. Sterbealter (z.B. †53J bei Person II4) angegeben. Bei den mit Sternchen (*) markierten Personen wurden molekulargenetische Untersuchungen durchgeführt.

Die betroffene Schwester des Indexpatienten (III2) leidet seit dem 31. Lebensjahr an einer progredienten Gangstörung und nutzt beim Laufen Unterarmgehstützen. Ihr Gang ist verlangsamt und die Gehstrecke ist mit maximal $500 \mathrm{~m}$ deutlich eingeschränkt. Nachts klagt sie über Muskelschmerzen und -krämpfe im Bereich von Oberschenkeln und Waden. Weiterhin leidet sie an einer rheumatoiden Arthritis, die sich durch Schmerzen und Steifigkeit der Gelenke äußert. Sie beklagt außerdem eine Dranginkontinenz. Nebenbefundlich konnte eine schwere pulmonale Diffusionsstörung gesichert werden. Bei der neurologischen Untersuchung fand sich ein normaler Muskeltonus, die Muskeldehnungsreflexe waren seitengleich schwach auslösbar. Bei der durchgeführten molekulargenetischen Untersuchung konnten die beiden familiären Mutationen nachgewiesen werden. Auch bei der betroffenen Mutter (II3) fanden sich diese Mutationen. Sie zeigt aber lediglich eine leicht ausgeprägte Gangstörung. Der betroffene Bruder (III3) leidet seit seinem 5. Lebensjahr an einer spastischen Gangstörung, welche im Vergleich zum Indexpatienten deutlich stärker ausgeprägt 
sein soll. Laufen sei kaum noch möglich. Der Patient III3 hat sich gegen eine molekulargenetische Untersuchung ausgesprochen. Der Großvater (I3) soll ebenfalls an einer Gangstörung gelitten haben, eine Untersuchung war nicht möglich, da dieser bereits im 2 . Weltkrieg verstorben ist. Der Vater des Indexpatienten (II4) verstarb nach beruflicher Asbestexposition und langjährigem Rauchen an einem metastasierten Kehlkopfkarzinom. Ein Onkel (II9) ist im Alter von 45 Jahren an den Folgen eines Zungenkrebses verstorben. Des Weiteren ist eine Tante (II10) mit langjähriger Raucheranamnese im Alter von 62 Jahren an Lungenkrebs verstorben. Aufgrund dieser Krankheitsfälle ist nebenbefundlich von einer Prädisposition für Krebsleiden auszugehen.

\subsubsection{Charakterisierung der Indexpatientin 28103 und ihrer Familie}

Die Patientin (IV8) zeigt ca. seit dem neunten Lebensjahr eine leichte Gangstörung, die sich bis zum Ende des zweiten Lebensjahrzehnts deutlich verschlechtert hat. Treppen hinabsteigen bereitet deutliche Probleme. Aktuell ist eine höhergradige Spastik der Beine mit leichter Parese festzustellen. Die Achilles- und Patellar-Sehnen-Reflexe sind lebhaft, das BabinskiZeichen ist rechts eindeutig positiv, links fraglich. Es sind keine Sensibilitätsstörungen festzustellen. Beim Gehen fallen eine leichte Innenrotation der Beine und eine Spitzfußstellung auf. Die Fersen berühren den Boden beim Gehen nicht. Eine Gehhilfe benötigt die Patientin nicht.

Die oberen Extremitäten sind nicht betroffen. Die Untersuchung der Hirnnerven ist unauffällig. Weitere neurologische Symptome wie Blasenentleerungsstörungen o.ä. liegen nicht vor.

Der in Abbildung 9 dargestellte Stammbaum zeigt die Familie der Indexpatientin 28103. Es ist $\mathrm{zu}$ sehen, dass der betroffene Bruder der Indexpatientin (IV12) seit dem 5. Lebensjahr Symptome aufweist. Laut Angaben der Patientin ist er mittlerweile rollstuhlabhängig, im Gegensatz zu ihr seien bei ihm auch die Arme betroffen. Er zeigt keine sonstigen neurologischen Symptome. Er ist molekulargenetisch untersucht worden und weist die bei der Indexpatientin vorliegende Mutation c.183-2A $>\mathrm{G}$ auf. Bei der gesunden Schwester (IV9) konnte die Mutation nicht nachgewiesen werden. Die verstorbene Schwester (IV11) litt neben ihrer Gangstörung an einer schweren Depression und lebte in Betreuung. Eine molekulargenetische Untersuchung war nicht möglich. 


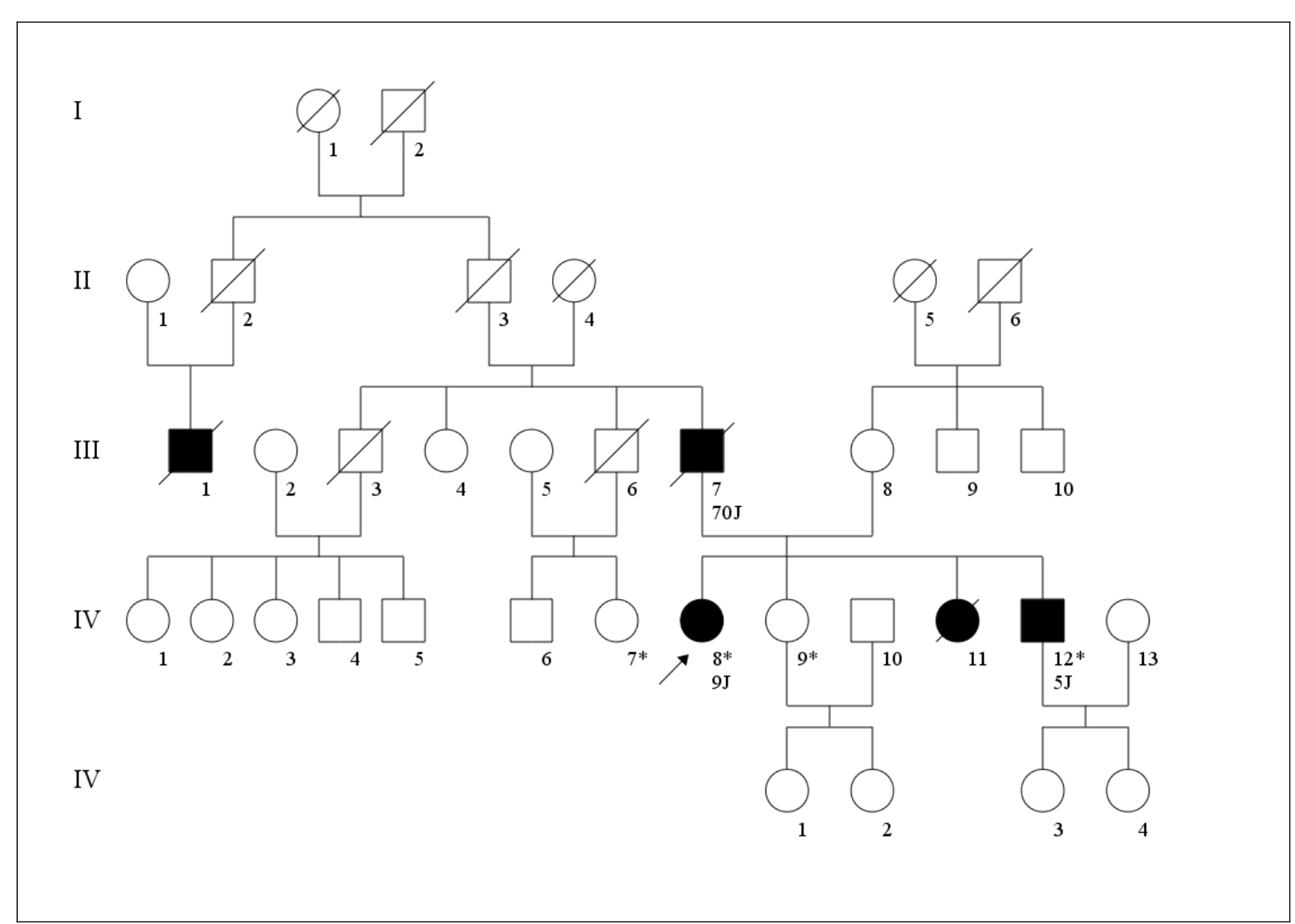

Abb. 9: Stammbaum der Patientin 28103 (IV 8).

Außer der Indexpatientin sind noch der Bruder (IV12), die Schwester (IV11), der Vater (III7) sowie ein Cousin des Vaters (III1) betroffen. Soweit bekannt ist das Erkrankungsalter der Betroffenen angegeben (z.B. 9 J bei Person IV8). Über eine mögliche Erkrankung der Personen II2 und II3 ist nichts bekannt. Bei den mit Sternchen (*) markierten Personen ist eine molekulargenetische Untersuchung durchgeführt worden.

Der verstorbene Vater (III7) zeigte ab dem 70. Lebensjahr eine leichte Gangstörung und benötigte einen Rollator. Eine HSP ist aber klinisch nicht sicher diagnostiziert worden. Die phänotyisch unauffällige Cousine (IV7) der Indexpatientin ist molekulargenetisch untersucht worden, die familiäre Mutation konnte nicht detektiert werden. Der Angehörige III1 habe ebenfalls an einer Gangstörung gelitten und orthopädische Schuhe getragen. Über das Gangbild der Personen II2 und II3 gibt es keine Informationen.

\subsection{Expressionsanalyse von REEP1 in verschiedenen humanen Geweben}

Das Gen SPG31 kodiert für das Receptor Expression-Enhancing-Protein 1 (REEP1). Züchner et al. (2006) konnten mittels RT-PCR nachweisen, dass REEP1 nahezu ubiquitär exprimiert 
wird, jedoch nicht in Zellen des peripheren Blutes oder primären Fibroblasten.

Bei den im Rahmen dieser Arbeit durchgeführten Expressionsanalysen wurde jeweils eine kommerziell erhältliche mRNA-Probe aus menschlichem Gehirn als Positivkontrolle eingesetzt. Um Kontaminationen mit Fremd-DNA auszuschließen, wurde zusätzlich eine Leerkontrolle ohne DNA mitgeführt. Zur Kontrolle der RNA wurden zusätzlich zu den SPG31-Primern, Oligonukleotide zur Amplifikation des Housekeeping-Gens HPRT verwendet. Housekeeping-Gene sind Gene, die für den Zellstoffwechsel essentiell sind und daher in jeder Zellart exprimiert werden.

\subsubsection{Mundschleimhaut und Zellen der Speicheldrüsen und -ausführungsgänge}

Die DNA-Isolation aus Speichelproben ist ein gängiges Verfahren in der Forensik (Montpetit et al. 2005). Auch die RNA-Isolation soll mithilfe kommerzieller Kits möglich sein. In der aktuellen Literatur ist bislang nicht beschrieben worden, ob SPG31 in Mundschleimhaut und in den im Speichel enthaltenen Zellen exprimiert wird.

\subsubsection{RNA-Isolation mittels TriFast-Reagenz}

Mithilfe des TriFast-Reagenz wurde eine RNA-Isolation durchgeführt, anschließend wurde mit dem Superscript-Kit und Oligo (dT)-Primern cDNA synthetisiert. Es folgte eine Amplifikation mit spezifischen Primern.

Auf dem Foto der Agarosegel-Elektrophorese (Abb. 10) im Anschluss an den zweiten Versuch, RNA aus Mundschleimhaut $\mathrm{zu}$ isolieren, konnten keine SPG31-PCR-Produkte nachgewiesen werden. Es ist jedoch zu sehen, dass die Amplifikation der Positivkontrolle (5) sowohl mit dem HPRT-Primerpaar als auch mit dem SPG31-Primerpaar funktioniert hat. Eine Verunreinigung des PCR-Ansatzes mit Fremd-DNA lag nicht vor (keine Bande für die Leerkontrolle (6)). Bei Probe 2 sieht man im Gel eine Bande für das Housekeeping-Gen $H P R T$, jedoch keine für SPG31. Die Proben 1, 3 und 4 enthielten zu geringe DNA-Mengen, sodass hier keine Banden nachweisbar waren. Auch bei mehrfacher Wiederholung des Versuches konnten keine PCR-Produkte der SPG31-cDNA nachgewiesen werden. 


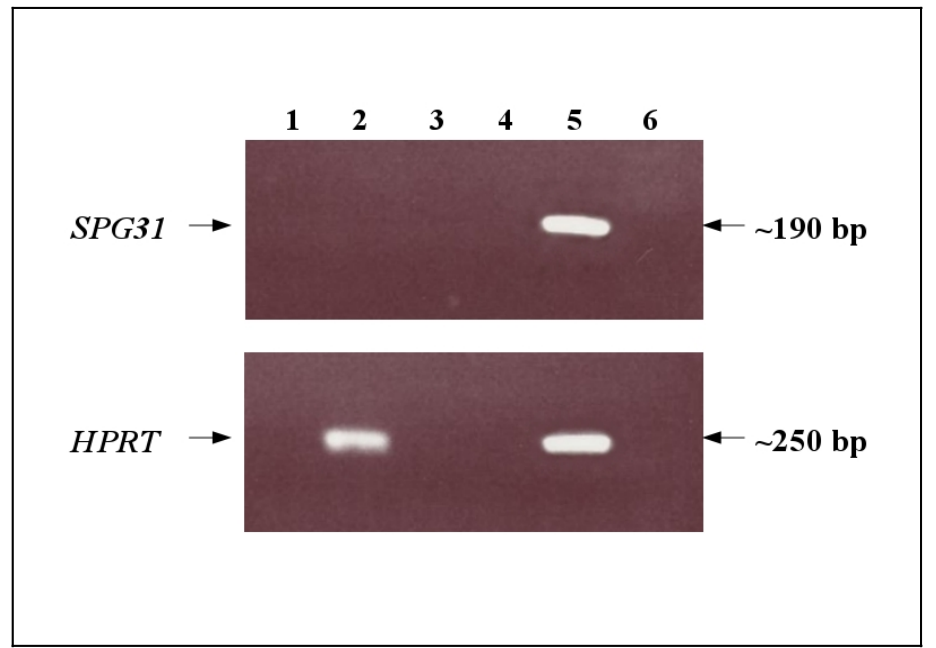

Abb. 10: cDNA-PCR-Produkte des zweiten Versuchs. RNA wurde aus Mundschleimhaut und Speichel isoliert, in cDNA umgeschrieben, mit den entspechenden Primern (HPRT bzw. SPG31) amplifiziert und dann auf ein 1,8\%-Agarosegel aufgetragen.

1) Mundschleimhaut von Person M.S., 2) Mundschleimhaut von Person C.K., 3) Mundschleimhaut von Person K.P., 4) Mundschleimhaut von Person S.W., 5) Positivkontrolle: menschliches Gehirn, 6) Leerkontrolle.

\subsubsection{RNA-Isolation mittels RNeasy Saliva Protect}

Da die RNA-Isolation mittels TriFast-Reagenz erfolglos war, wurde das spezielle RNeasy Saliva Protect-Kit für die RNA-Isolation aus Speichel verwendet. Alle Reaktionsschritte wurden exakt nach Herstellerprotokoll ausgeführt. Auch für die cDNA-Synthese und die anschließende PCR wurde ein Kit eingesetzt, das die beiden Reaktionsschritte Reverse Transkription und PCR kombiniert (OneStep RT-PCR). So sollten Kontaminationen verringert und die Ausbeute erhöht werden.

Die Abbildung 11 zeigt, dass die Amplifikation der Positivkontrolle (5) sowohl mit dem HPRT-Primerpaar als auch mit dem SPG31-Primerpaar funktioniert hat. Eine Verunreinigung des PCR-Ansatzes mit Fremd-DNA lag nicht vor (keine Bande für die Leerkontrolle (6)). Es konnten keine cDNA-Amplifikate aus Mundschleimhaut erhalten werden. Auch nach mehrfacher Wiederholung unter Zuhilfenahme des speziellen Kits konnten keine spezifischen Banden der PCR-Produkte aus Mundschleimhaut und aus im Speichel enthaltenen Epithelien erhalten werden. 


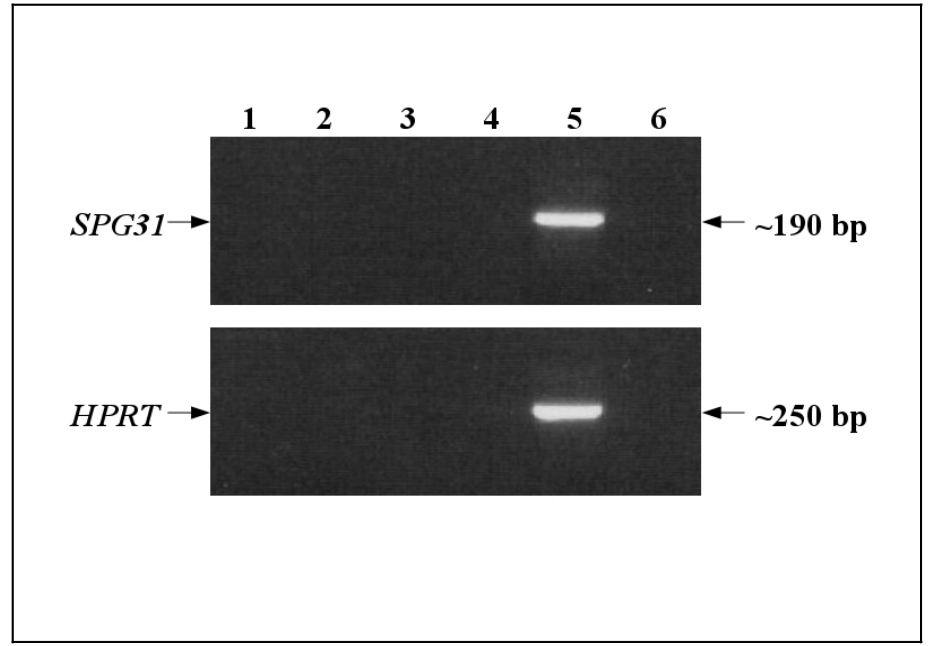

Abb. 11: cDNA-PCR-Produkte des vierten Versuchs. RNA wurde aus Mundschleimhaut und Speichel isoliert, in cDNA umgeschrieben, mit den entspechenden Primern (HPRT bzw. SPG31) amplifiziert und dann auf ein 1,8\%-Agarosegel aufgetragen.

1) Mundschleimhaut von Person M.S. Probe 1, 2) Mundschleimhaut von Person M.S. Probe 2, 3) Mundschleimhaut von Person C.K. Probe 1, 4) Mundschleimhaut von Person C.K. Probe 2, 5) Positivkontrolle: menschliches Gehirn, 6) Leerkontrolle.

\subsubsection{RNA aus Urothelzellen und Epithelien der ableitenden Harnwege aus Spontanurin}

Urin und die darin enthaltenen abgeschilferten Zellen stellen ein weiteres nicht-invasiv und leicht zu gewinnendes Material dar. Für die Versuche wurde frischer Mittelstrahl-Spontanurin verwendet. Nach Zentrifugation und RNA-Isolation mittels TriFast-Reagenz, Reverser Transkription und PCR wurden die Proben auf ein 1,8\% (w/v)-Agarosegel aufgetragen.

Im Agarosegel (Abb. 12) konnte bei Probe 4) zwar ein Schleier kleinerer cDNA-Fragmente, aber keine spezifische Bande für SPG31-Amplifikate nachgewiesen werden. Die Probe 5 zeigt eine schwache Bande für SPG31, da aber kein HPRT-Produkt nachweisbar war, wurde dies als Artefakt gedeutet. Bei keiner der übrigen Urin-Proben sind Banden für SPG31- oder HPRT-PCR-Produkte sichtbar. Die Positivkontrolle (6) zeigt eindeutige Banden für SPG31und HPRT-Produkte. Eine Verunreinigung der Leerkontrolle (7) ist nicht zu sehen. Auch bei wiederholten Versuchen, RNA aus Urin $\mathrm{zu}$ isolieren, konnte keine SPG31-mRNA nachgewiesen werden. 


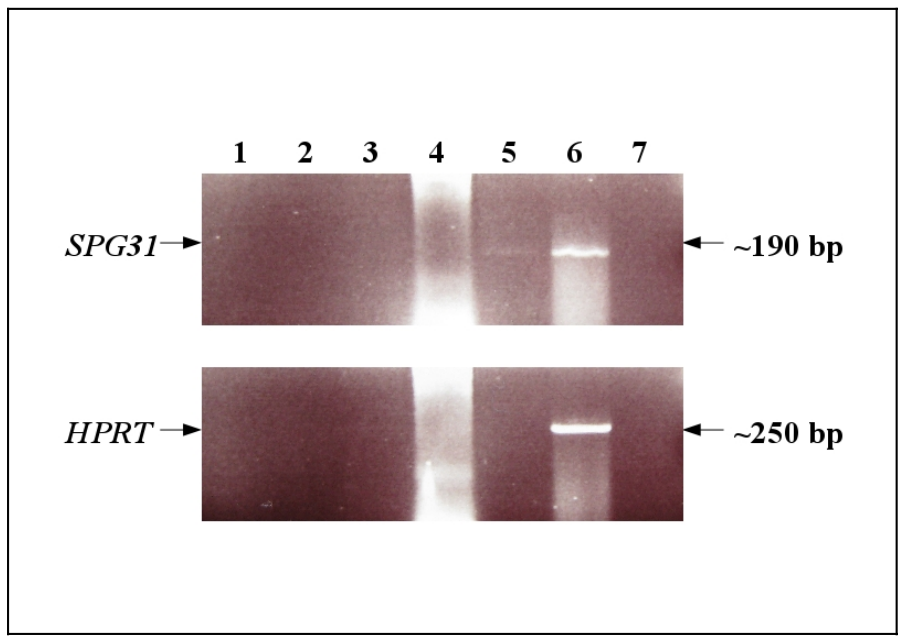

Abb. 12: cDNA-PCR-Produkte des dritten Versuchs. RNA wurde aus Urothelzellen isoliert, in cDNA umgeschrieben, mit den entspechenden Primern (HPRT bzw. SPG31) amplifiziert und dann auf ein 1,8\%-Agarosegel aufgetragen

1) Urin von Person S.W., 2) Urin von Person M.S. Probe 1, 3) Urin von Person C.K., 4) Urin von Person M.S. Probe 2, 5) Urin von Person N.V., 6) menschliches Gehirn, 7) Leerkontrolle.

\subsubsection{RNA-Isolation aus Haarwurzeln}

Da die Isolierung von DNA aus Haarwurzeln ein bereits etabliertes Verfahren darstellt (Suenaga et al. 2005), sollte nun versucht werden RNA aus Haarwurzeln zu gewinnen. Die Kopfhaare wurden mithilfe einer Pinzette ausgezupft. Unter dem Lichtmikroskop wurde kontrolliert, ob die Haarwurzeln vorhanden waren. Die Haare wurden von der Wurzel ausgehend auf 1-2 cm Länge gekürzt und in ein Eppendorf Cup überführt. Nach Zerstoßen der Haarwurzel erfolgte die RNA-Isolation. Es schloss sich eine Reverse Transkription der Gesamt-RNA mit dem Superscript-Kit und Oligo (dT)-Primern an.

Die Abbildung 13 zeigt die Ergebnisse des ersten Versuchs. Es konnte ein SPG31-PCRProdukt für die Haarprobe nachgewiesen werden, jedoch ist die Bande für das HousekeepingGen HPRT nur schwach zu erahnen. Die Positivkontrolle ist in beiden Fällen positiv, die Leerkontrolle zeigt keine Banden. In Abbildung 14 sind bei allen Haarproben und auch bei der Positivkontrolle Banden für SPG31 und HPRT-PCR-Produkte sichtbar. Eine Kontamination der Leerkontrolle ist nicht zu sehen. 


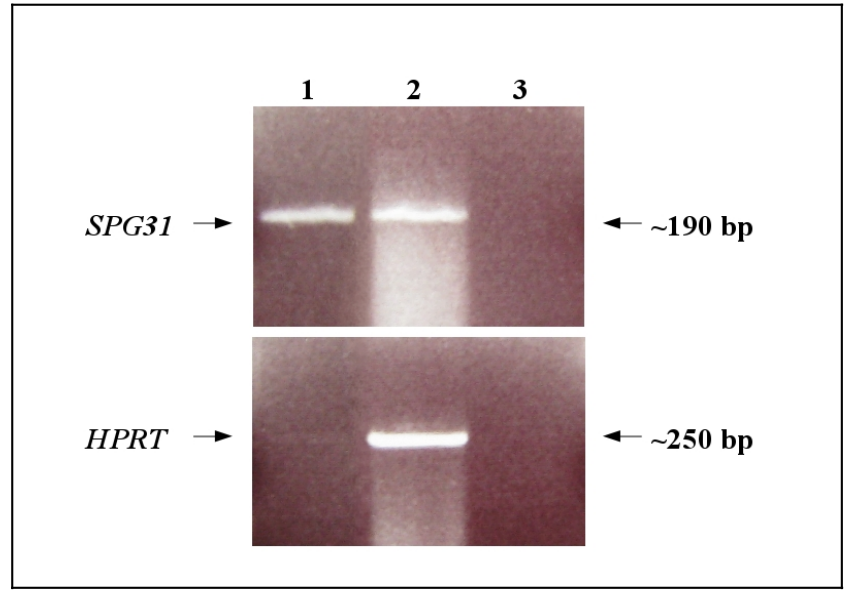

Abb. 13: cDNA-PCR-Produkte aus dem ersten Versuch, RNA aus Haarwurzeln zu isolieren, aufgetragen auf ein 1,8\%-Agarosegel.

1) Haar von Person S.W (brünett)., 2) Positivkontrolle: menschliches Gehirn, 3) Leerkontrolle.

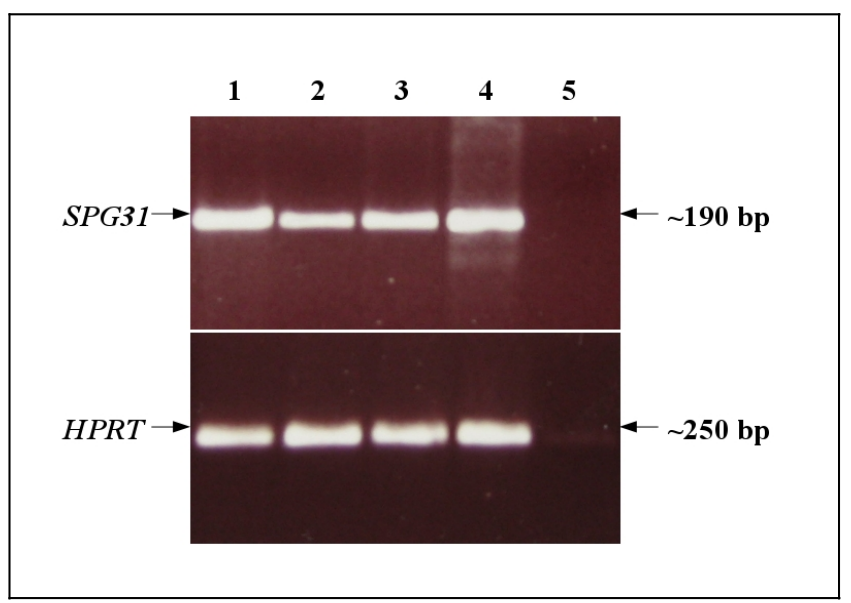

Abb. 14: cDNA-PCR-Produkte aus dem vierten Versuch, RNA aus Haarwurzeln zu isolieren, aufgetragen auf ein 1,8\%-Agarosegel.

1) Haar von Person M.S. (schwarzhaarig) Probe 1, 2) Haar von Person M.S. (schwarzhaarig) Probe 2, 3) Haar von Person S.W. (brünett), 4) Positivkontrolle: menschliches Gehirn, 5) Leerkontrolle.

Das Foto des Agarosegels (Abb. 15) zeigt die Ergebnisse von drei unabhängigen RNAIsolationen (Versuche 6, 7 und 8, vgl. Tab. 7). Die Reverse Transkription und die anschließende PCR wurden für alle Proben zusammen durchgeführt. Es sind deutliche Banden für die Positivkontrolle zu sehen. Da keine Banden für die Leerkontrolle sichtbar sind, ist eine Kontamination nicht anzunehmen. Für alle Haarproben von Person M.S. sind sowohl SPG31als auch HPRT-Banden zu sehen. Bei Person S.W. sind bei der ersten Isolation beide Banden 
sichtbar, bei der zweiten Isolation ist die HPRT-Kontrolle ausgefallen, bei der dritten Isolation sind keine PCR Produkte für SPG31 und HPRT nachweisbar.

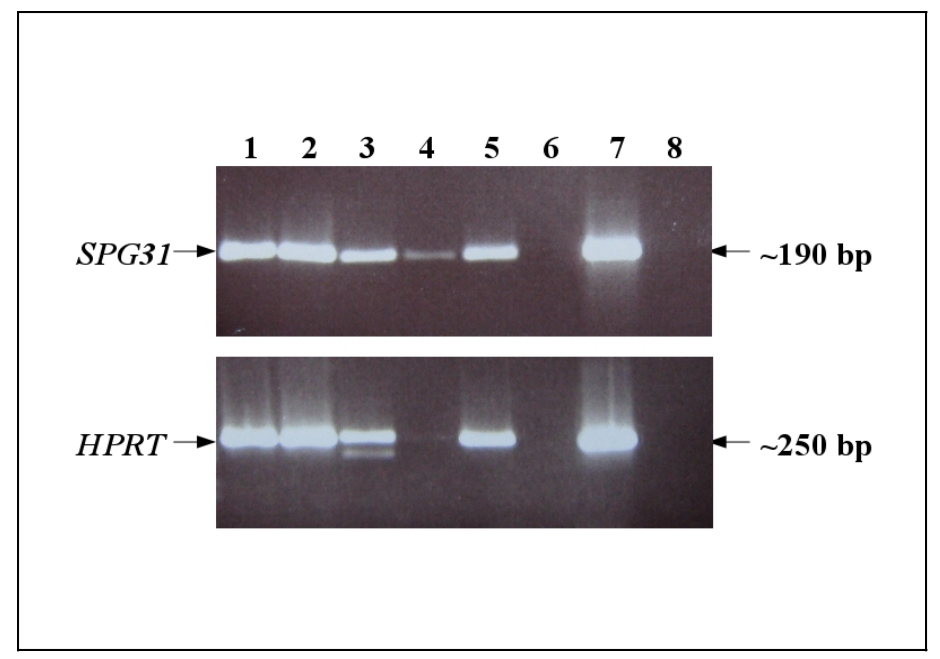

Abb. 15: cDNA-PCR-Produkte dreier unabhängiger Versuche, RNA aus Haarwurzeln zu isolieren, aufgetragen auf ein 1,8\%-Agarosegel.

1) Haar von Person M.S. (schwarzhaarig) 1. Isolation, 2) Haar von Person S.W. (brünett) 1. Isolation, 3) Haar von Person M.S. (schwarzhaarig) 2. Isolation, 4) Haar von Person S.W. (brünett) 2. Isolation, 5) Haar von Person M.S. (schwarzhaarig) 3. Isolation, 6) Haar von Person S.W. (brünett) 3. Isolation, 7) Positivkontrolle: menschliches Gehirn, 8) Leerkontrolle.

In der Tabelle 7 sind die Ergebnisse aller Versuche zusammengestellt. Es ist zu sehen, dass vor allem bei den schwarzhaarigen Probanden der Nachweis von SPG31- und HPRT-PCRProdukten sehr zuverlässig gelang. 
Tab. 7: Übersicht über alle durchgeführten Versuche, RNA aus Haarwurzeln zu isolieren und daran die SPG31-Expression nachzuweisen.

Für die Versuche 2, 3 und 5 sind oben keine Agarosegel-Fotos aufgeführt.

\begin{tabular}{|c|c|c|c|c|c|}
\hline Versuch & Person & Haarfarbe & SPG31-Nachweis & HPRT-Nachweis & weiterer Primer/ Nachweis \\
\hline 1 & S.W. & brünett & ja & sehr schwach & \\
\hline \multirow[t]{3}{*}{2} & S.W. & brünett & nein & nein & $\beta$-Aktin/ ja \\
\hline & K.P. & schwarz & ja & ja & $\beta-A k t i n /$ ja \\
\hline & M.S. & schwarz & Fragmente & ja & $\beta-A k t i n /$ ja \\
\hline \multirow[t]{3}{*}{3} & M.M. & brünett & nein & nein & \\
\hline & L.B. & blond & nein & nein & \\
\hline & K.P. & schwarz & ja & ja & \\
\hline \multirow[t]{3}{*}{4} & M.S. & schwarz & ja & ja & \\
\hline & M.S. & schwarz & ja & ja & \\
\hline & S.W. & brünett & ja & ja & \\
\hline \multirow[t]{2}{*}{5} & M.S. & schwarz & ja & ja & $\beta-A k t i n /$ ja \\
\hline & S.W. & brünett & ja & ja & $\beta$-Aktin/ ja \\
\hline \multirow[t]{2}{*}{6} & M.S. & schwarz & ja & ja & $\beta$-Aktin/ ja \\
\hline & S.W. & brünett & ja & ja & $\beta$-Aktin/ ja \\
\hline \multirow[t]{2}{*}{7} & M.S. & schwarz & ja & ja & $\beta-A k t i n /$ ja \\
\hline & S.W. & brünett & schwach & nein & B-Aktin/ schwach \\
\hline \multirow[t]{2}{*}{8} & M.S. & schwarz & ja & ja & $\beta$-Aktin/ ja \\
\hline & S.W. & brünett & nein & nein & $\beta$-Aktin/ nein \\
\hline
\end{tabular}

\subsection{Effekt von Mutationen im Bereich von miRNA-Bindestellen}

Mikro-RNAs sind kleine regulatorische RNA-Sequenzen. Durch miRNA-Anlagerung an partiell komplementäre 3'UTR-Sequenzen kann die Proteinbiosynthese beeinflusst werden. Die miR-691 ist partiell komplementär zu dem Teil der SPG31-3'UTR, in dem eine HSPverursachende Mutation beschrieben wurde (s. Abb. 16) (Beetz et al. 2008). Durch einen Luciferase-Assay sollte untersucht werden, welchen Effekt diese Mutation auf die Bindung der miR-691 und damit auf die Expression des SPG31-Gens hat. 


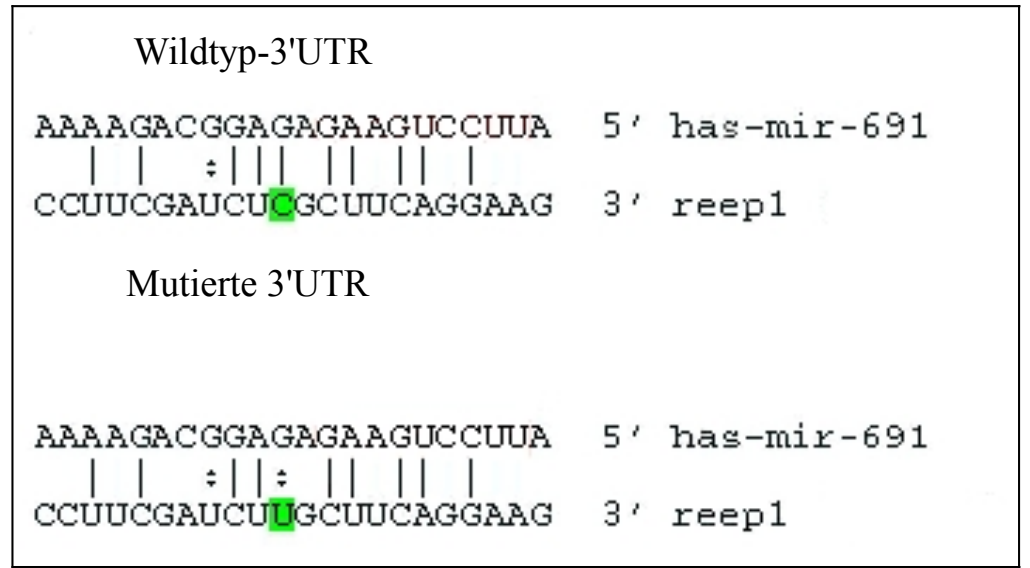

Abb. 16: Bindung der miR-691 an Wildtyp-3'UTR und mutierte 3'UTR.

Die grün hinterlegte Base zeigt die Position der Mutation c.606+14C>T, an dieser Stelle ist die Wildtyp-3'UTR-Sequenz komplementär zur miR-691.

Zunächst wurden die gewünschten Mutationen (c.605A $>\mathrm{G}$ und c.606 $+14 \mathrm{C}>\mathrm{T}$ ) mittels zielgerichteter Mutagenese in die 3'UTR einer Wildtyp-DNA-Sequenz integriert. Es schloss sich eine Amplifikation der veränderten SPG31-3'UTR mitsamt ca. 250 bp-langen flankierenden Sequenzen an (s. Abb. 17). Dazu wurde das Primerpaar „3'UTR“ verwendet. Der Vorwärts-Primer enthielt eine Schnittstelle für das Restriktionsenzym HindIII, der Rückwärts-Primer eine für das Enzym SacI (=SstI). Eine Wildtyp-3'UTR wurde als Kontrolle mitgeführt.

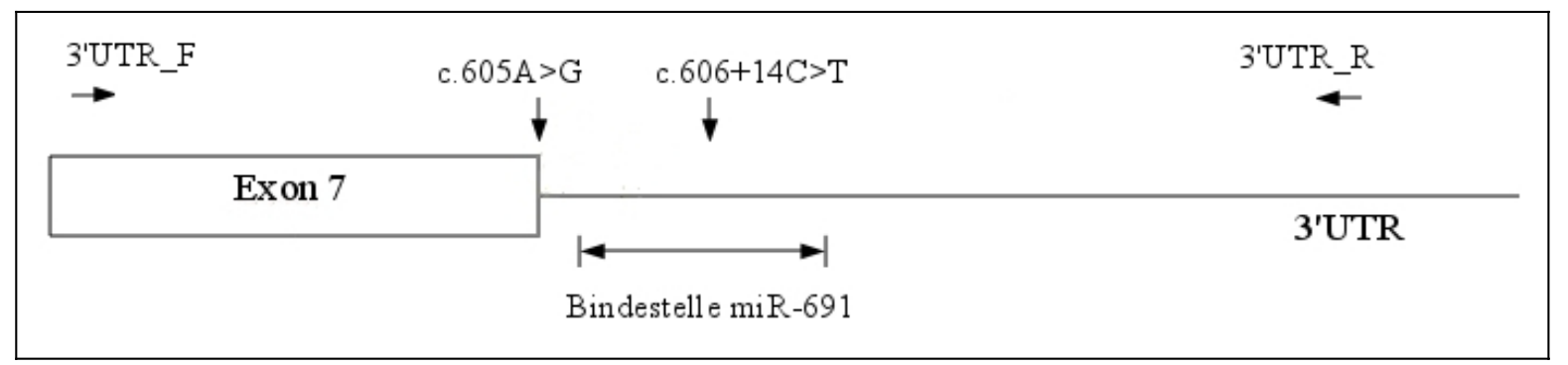

Abb. 17: Schema der für den Luciferase-Assay eingesetzten mutierten 3'UTR.

Die vertikalen Pfeile markieren die beiden Mutationen. Mit dem Primerpaar 3'UTR_F und 3'UTR_R (horizontale Pfeile) wurde eine 679 bp-lange Sequenz amplifiziert, die beide Mutationen enthält.

Die entstandenen 679 bp-langen Produkte wurden in den Vektor pGEM-T Easy (Vektorkarte s. Abb. 5) kloniert und in DH5a-Zellen vermehrt. An die Plasmid-Präparation schloss sich ein Restriktionsverdau mit HindIII und SstI an. Mittels Agarosegel-Elektrophorese wurden die Fragmente aufgetrennt und die Inserts konnten aus dem Gel isoliert werden. Zum Ausschluss 
von neu entstandenen Mutationen im Konstrukt wurde eine Sequenzanalyse mithilfe der 3'UTR-Primer durchgeführt.

Auch der in Abbildung 18 dargestellte pMIR REPORT miRNA Expression Reporter (im Folgenden: pMIR_Luc) wurde mit HindIII und SstI verdaut und aus einem Agarosegel isoliert.

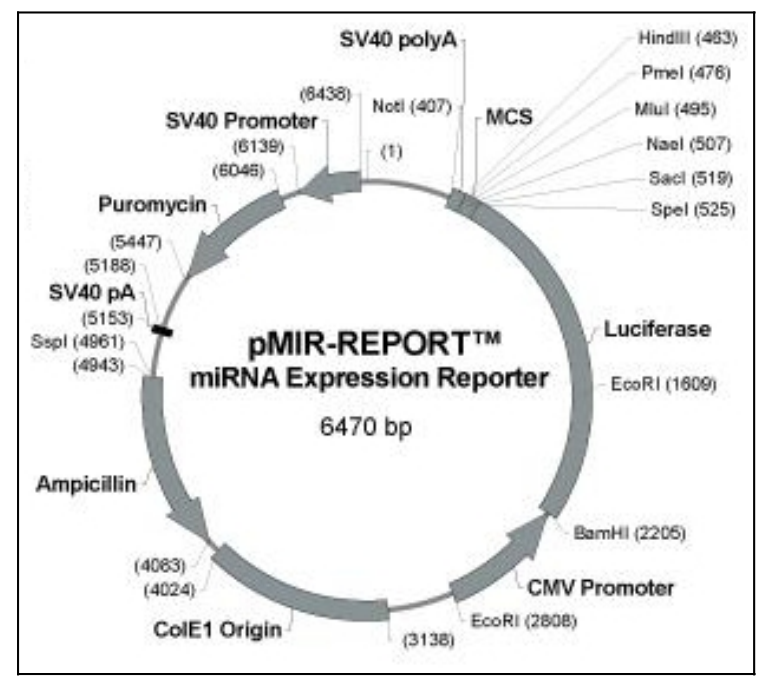

Abb. 18: Schema des Vektors pMIR-REPORT miRNA Expression Reporter für den Luciferase-Assay. Mit MCS ist die Stelle markiert, in die die 3'UTR integriert wurde. Diesen Bereich flankieren besonders viele Restriktionsschnittstellen. Upstream davon ist das Gen für das Enzym Luciferase gelegen. Es finden sich außerdem Gene, die für die Resistenz gegen die Antibiotika Puromycin und Ampicillin kodieren.

Das auf diesem Vektor kodierte Firefly-Enzym Luciferase katalysiert die in Abbildung 19 dargestellte Reaktion, bei der Licht emittiert wird (De Wet et al. 1985, Ow et al.1986). Schließlich wurde das 3'UTR-Konstrukt in den pMIR_Luc-Vektor ligiert. Zur Kontrolle wurde ein Restriktionsverdau mit HindIII und SstI durchgeführt, anschließend wurden die entstandenen Fragmente elektrophoretisch aufgetrennt (1\% Agarosegel).

$$
\text { Luciferin }+\mathrm{ATP}+\mathrm{O}_{2} \rightarrow \text { Oxiluciferin }+\mathrm{AMP}+\mathrm{CO}_{2}+\text { Licht }
$$

Abb. 19: Reaktionsgleichung der vom Enzym Luciferase katalysierten Reaktion. 
Nach Vermehrung des Vektors in DH5 $\alpha$-Zellen wurde das Konstrukt in präparativem Maßstab isoliert. Um unerwünschte Mutationen im Insert auszuschließen und die Lage des Inserts im Vektor zu überprüfen, wurde eine Sequenzierung mit dem Primerpaar pMIR durchgeführt. Die verwendeten pMIR-Primer sind komplementär $\mathrm{zu}$ den die MCS-flankierenden Vektorabschnitten.

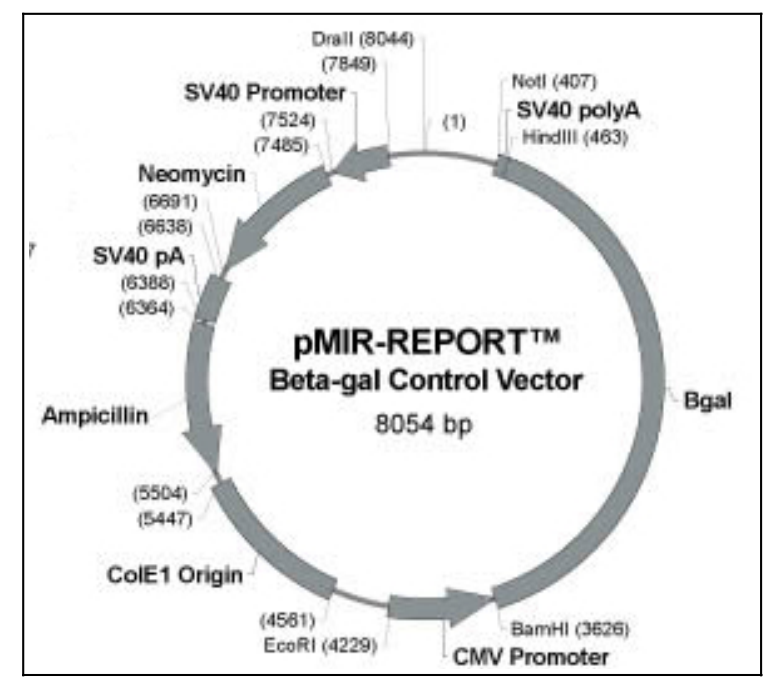

Abb. 20: Schema des pMIR REPORT Beta-Gal Control-Vektors.

Der Vektor enthält neben verschiedenen Restriktionschschnittstellen die Gene für die Resistenz gegen Neomycin und Ampicillin sowie für das Enzym $\beta$-Galaktosidase,.

Es schloss sich die Kultur und Transfektion der 3T3-Zellen in unterschiedlichen Versuchsanordnungen (Transfektionsansätze s.u.) an. Es wurde jeweils der in Abbildung 20 dargestellte pMIR REPORT Beta-Gal Control Vector (im Folgenden: pMIR_ßGal) zur späteren Normalisierung mitgeführt. Alle Transfektionen wurden dreifach durchgeführt.

Bei der anschließenden Messung der Biolumineszenz wurde die Lichtemission mit der Menge der entstandenen Luciferase korreliert. Alle Substrate des Enzyms sind im Überschuss im Reaktionsansatz vorhanden, so dass die Lichtemission einzig durch die Luciferase-Menge limitiert wird. Für jede Probe wurden zwei Messungen durchgeführt, somit ergaben sich pro Transfektionsansatz sechs Messwerte. Unter der Annahme, dass pMIR_Luc und pMIR_ $\beta G a l$ in gleichem Maße in die 3T3-Zellen aufgenommen wurden, wurden die gemessenen Lumineszenz-Werte gegen die entsprechenden $\beta$-Galactosidase-Werte normalisiert. Dadurch sollten Unterschiede in der Transfektionseffizienz als mögliche Fehlerquellen ausgeschlossen 
werden. Die relative Lumineszenz der mutierten Probe wurde mit der der Wildtyp-Probe verglichen. So konnten Rückschlüsse gezogen werden, welchen Effekt die Mutation auf die posttranskriptionelle Regulation hat.

Im ersten Versuch wurden folgende Transfektionen durchgeführt:

1. pMIR Luc-Vektor mit WT-3'UTR + pMIR $\beta$ Gal-Vektor

2. pMIR_Luc-Vektor mit WT-3'UTR + pMIR_BGal-Vektor ～+ Kontroll-miRNA

3. pMIR_Luc-Vektor mit mutierter 3'UTR + pMIR_ $\beta$ Gal-Vektor $\quad+$ miR-691

4. pMIR_Luc-Vektor mit mutierter 3'UTR + pMIR_ßGal-Vektor + Kontroll-miRNA

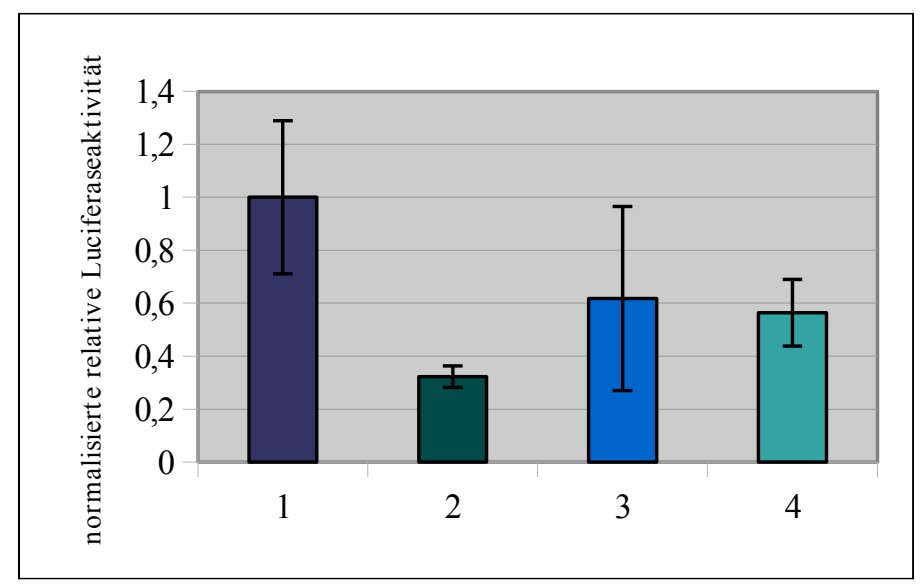

Abb. 21: Graphische Darstellung der gegen den Mittelwert der Probe 1 normalisierten Messergebnisse der ersten Transfektion.

1) $\left.p M I R \_L u c\left(W T-3^{\prime} U T R\right)+p M I R \_\beta G a l+m i R-6912\right) p M I R \_L u c\left(W T-3^{\prime} U T R\right)+p M I R \_\beta G a l+$ Kontroll-miR 3) pMIR_Luc (mutierte $\left.3^{\prime} U T R\right)+p M I R \_\beta G a l+m i R-691$ 4) pMIR_Luc (mutierte $\left.3^{\prime} U T R\right)+p M I R \_\beta G a l+$ Kontroll-miR

Die Abbildung 21 zeigt die Ergebnisse der gegen die Wildtyp-Probe mit miR-691 (1) normalisierten Messwerte. Es ist zu sehen, dass die Luciferase-Aktivität der mutierten Probe mit miR-691 (3) geringer ist als die der Wildtyp-Probe (1). Auffällig ist, dass die WildtypProbe mit Kontroll-miR (2) eine deutlich erniedrigte Luciferase-Aktivität zeigt. Bei Verwendung des Vektors mit mutierter 3'UTR (3 und 4) sind beide Messwerte etwa auf gleichem Level.

Nach Erhalt der oben genannten Ergebnisse wurde der Versuch umstrukturiert, sodass die zweite Transfektion folgende Ansätze beinhaltete.
1. pMIR_Luc-Vektor mit WT-3'UTR
+ pMIR_ßGal-Vektor
$+\operatorname{miR}-691$
2. pMIR_Luc-Vektor mit WT-3'UTR
+ pMIR_ßGal-Vektor
+ Kontroll-miRNA 
3. pMIR_Luc-Vektor mit mutierter 3'UTR + pMIR_ $\beta$ Gal-Vektor $\quad+$ miR-691

4. pMIR_Luc-Vektor mit mutierter 3'UTR + pMIR_ßGal-Vektor ～+ Kontroll-miRNA

5. pMIR_Luc-Vektor ohne Insert $\quad+$ pMIR_ßGal-Vektor $\quad+$ miR-691

6. pMIR_Luc-Vektor ohne Insert + $\quad+$ pMIR_ßGal-Vektor $\quad+$ Kontroll-miRNA

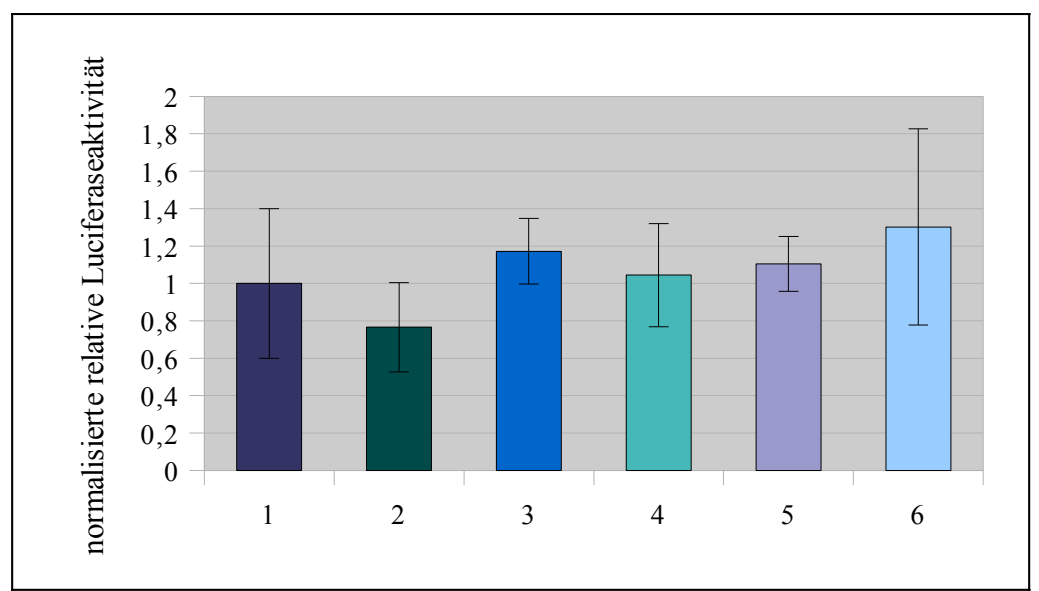

Abb. 22: Graphische Darstellung der gegen den Mittelwert der Probe 1 normalisierten Messergebnisse der zweiten Transfektion.

1) $\left.p M I R \_L u c\left(W T-3^{\prime} U T R\right)+p M I R \_\beta G a l+m i R-6912\right) p M I R \_L u c\left(W T-3^{\prime} U T R\right)+p M I R \_\beta G a l+$ Kontroll-miR 3) pMIR_Luc (mutierte 3'UTR) + pMIR_BGal + miR-691 4) pMIR_Luc (mutierte $\left.3^{\prime} U T R\right)+p M I R \_\beta G a l+$ Kontroll-miR 5) pMIR_Luc (ohne Insert) $+p M I R \_\beta G a l+m i R-691$ 6) pMIR_Luc (ohne Insert) + pMIR_ $\beta$ Gal + Kontroll-miR.

In Abbildung 22 ist zu sehen, dass die Luciferase-Aktivität der Probe mit Vektor ohne Insert mit Kontroll-miR (6) am stärksten ist, die der Wildtyp-Probe mit Kontroll-miR (2) am geringsten. Die Luciferase-Aktivität der übrigen Proben ist auf einem ähnlich hohen Niveau. Bei der Probe 6) fällt auf, dass im Gegensatz zu den übrigen Proben die Luciferase-Aktivität der Probe mit Kontroll-miR stärker ist als die der Probe mit miR-691 (5).

Um die obigen Ergebnisse zu validieren, erfolgte eine dritte Transfektion mit gleichen Transfektionsansätzen, die Ergebnisse sind in Abbildung 23 dargestellt. 


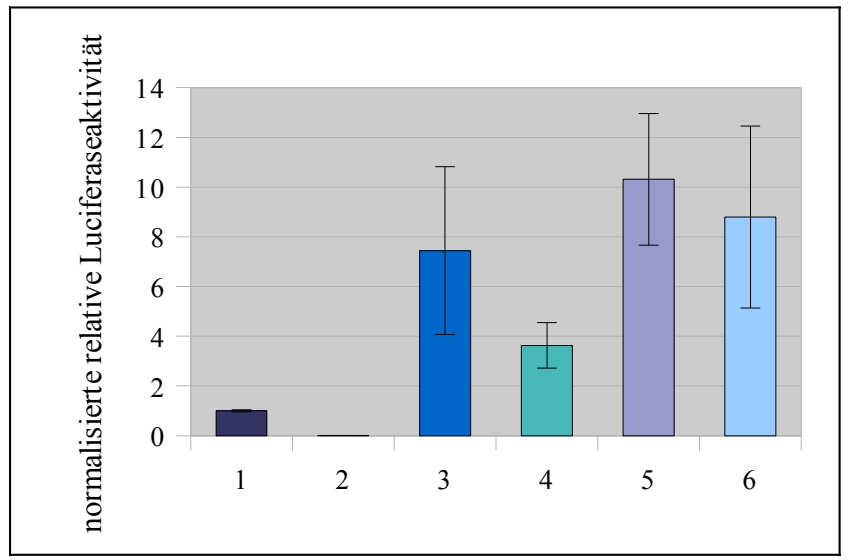

Abb. 23: Graphische Darstellung der gegen den Mittelwert der Probe 1 normalisierten Messergebnisse der dritten Transfektion.

1) $p M I R \_L u c\left(W T-3^{\prime} U T R\right)+p M I R \_\beta G a l+m i R-691$ 2) $p M I R \_L u c\left(W T-3^{\prime} U T R\right)+p M I R \_\beta G a l+$ Kontroll-miR 3) pMIR_Luc (mutierte 3'UTR) + pMIR_BGal + miR-691 4) pMIR_Luc (mutierte $\left.\left.3^{\prime} U T R\right)+p M I R \_\beta G a l+K o n t r o l l-m i R ~ 5\right) \quad p M I R \_L u c$ (ohne Insert) $+p M I R \_\beta G a l+m i R-691$ 6) pMIR_Luc (ohne Insert) + pMIR_ $\beta G a l+$ Kontroll-miR.

Es ist zu sehen, dass die Luciferase-Aktivität der beiden Wildtyp-Proben (1 und 2), verglichen mit den Werten der übrigen Proben, extrem gering ist (vgl. Abb. 23). Bei den Proben mit Vektor ohne Insert (5 und 6) ist die Luciferase-Aktivität am stärksten. Bei allen Proben ist die Aktivität bei Verwendung der Kontroll-miR geringer als bei Einsatz der miR-691.

Die Ergebnisse der zweiten und dritten Transfektion veranlassten zur erneuten Modifikation der Transfektionsansätze für den vierten, fünften und sechsten Versuch.

1. pMIR_Luc-Vektor mit WT-3'UTR + pMIR_ßGal-Vektor $\quad+$ miR-691

2. pMIR_Luc-Vektor mit mutierter 3'UTR + pMIR_ßGal-Vektor $\quad+$ miR-691

3. pMIR_Luc-Vektor ohne Insert $\quad+$ pMIR_ßGal-Vektor $\quad+$ miR-691 


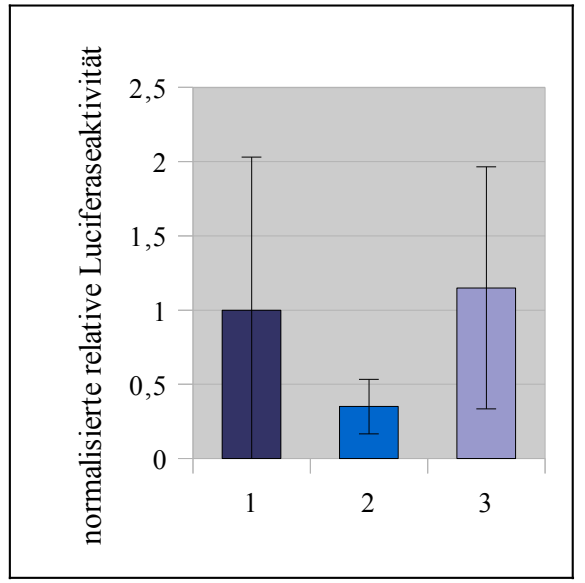

Abb. 24: Graphische Darstellung der gegen den Mittelwert der Probe 1 normalisierten Messergebnisse der vierten Transfektion.

1) $p M I R \_L u c\left(W T-3^{\prime} U T R\right)+p M I R \_\beta G a l+m i R-691$ 2) pMIR_Luc $\left(m u t i e r t e 3^{\prime} U T R\right)+p M I R \_\beta G a l+$ miR-691 3) pMIR_Luc (ohne Insert) + pMIR_ $\beta G a l+m i R-691$.

Die Abbildung 24 zeigt, dass die Luciferase-Aktivität der mutierten Probe (2) im Verhältnis zur Wildtyp-Probe (1) geringer ist. Bei der Probe mit dem Vektor ohne Insert (3) zeigt sich die stärkste Luciferase-Aktivität.

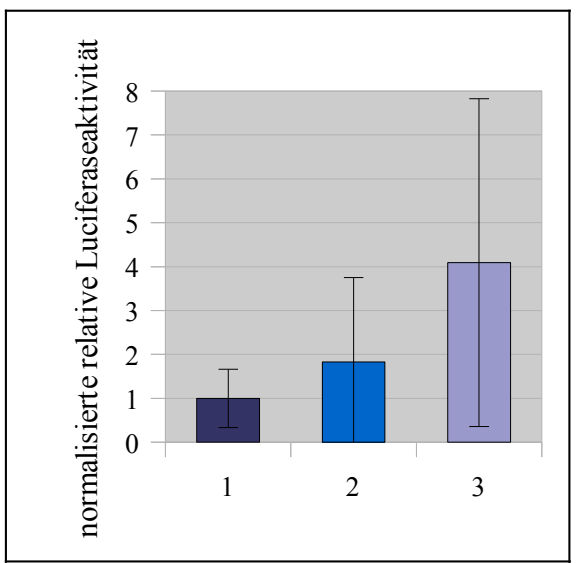

Abb. 25: Graphische Darstellung der gegen den Mittelwert der Probe 1 normalisierten Messergebnisse der fünften Transfektion.

1) $p M I R \_L u c\left(W T-3^{\prime} U T R\right)+p M I R \_\beta G a l+m i R-691$ 2) $p M I R \_L u c\left(m u t i e r t e 3^{\prime} U T R\right)+p M I R \_\beta G a l+$ miR-691 3) pMIR_Luc (ohne Insert) + pMIR_BGal + miR-691.

Im oben dargestellten Säulendiagramm (Abb. 25) sind die Ergebnisse der fünften Transfektion dargestellt. Man sieht, dass die Luciferase-Aktivität der Probe mit Vektor ohne Insert (3) deutlich stärker ist als die des Wildtyps (1). Auch die Luciferase-Aktivität des mutierten Konstrukts (2) ist stärker als die Aktivität bei der Wildtyp-Probe. 


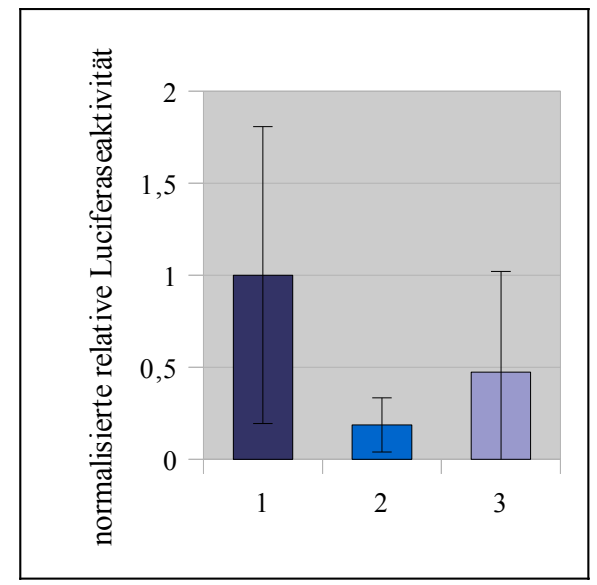

Abb. 26: Graphische Darstellung der gegen den Mittelwert der Probe 1 normalisierten Messergebnisse der sechsten Transfektion.

1) $p M I R \_L u c\left(W T-3{ }^{\prime} U T R\right)+p M I R \_\beta G a l+m i R-691$ 2) pMIR_Luc $\left(\right.$ mutierte $\left.3^{\prime} U T R\right)+p M I R \_\beta G a l+$ miR-691 3) pMIR_Luc (ohne Insert) + pMIR_ $\beta G a l+m i R-691$.

In Abbildung 26 ist zu sehen, dass die Luciferase-Aktivität der Probe mit mutiertem Konstrukt (2) im Verhältnis zur Wildtypprobe (1) sehr gering ist. Die Aktivität der Kontrollprobe mit unverändertem Vektor (3) ist ebenfalls gering, aber stärker als die der mutierten Probe. Die Ergebnisse dieser Transfektion unterscheiden sich deutlich von denen der vorherigen Transfektionen.

Zusammenfassend lässt sich feststellen, dass die Ergebnisse der Lumineszenz-Messungen sehr inkonstant sind. Es zeigen sich sehr stark divergierende Messwerte in den einzelnen Transfektionen und sehr hohe Standardabweichungen bei Bildung der Mittelwerte. 


\section{Diskussion}

\subsection{Molekulargenetik der Hereditären Spastischen Paraplegie Typ 31}

In der vorliegenden Arbeit steht die Hereditäre Spastische Paraplegie Typ 31 im Vordergrund. Diese Form der spastischen Paraplegie wird durch Mutationen im SPG31-Gen (REEP1-Gen) hervorgerufen.

Wie die Abbildung 27 zeigt, umfasst das bisher beschriebene Mutationsspektrum 42 verschiedene genetische Veränderungen, darunter sind kleine (wenige Basenpaare umfassende) und große (ein oder mehrere Exons lange) Deletionen, Duplikationen und Insertionen; Splice-Site-, Missense- und Nonsense-Mutationen sowie Mutationen, die regulatorisch wichtige Sequenzen betreffen (Human Gene Mutation Database, http://www.biobase-international.com 22.01.2013). Es gibt keinen sog. Hotspot-Bereich, in dem besonders viele Mutationen vorliegen. Jedes der sieben Exons kann von Mutationen betroffen sein.

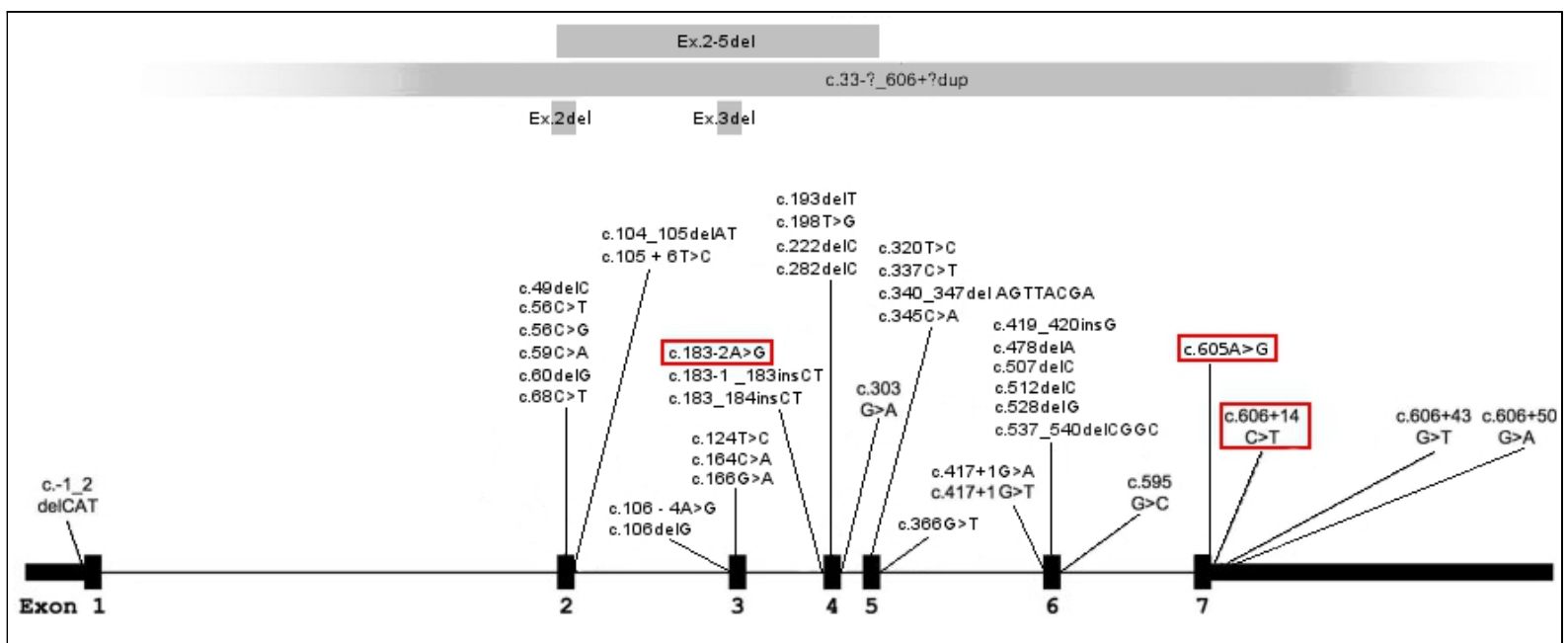

Abb. 27: Übersicht über die bislang beschriebenen Mutationen in REEP1.

Es kann jedes der sieben Exons betroffen sein. Der graue Balken ,c.33-?_606+?dup“ zeigt eine große Duplikation, die im Intron 1 beginnt und weit über den 3'-codierenden Bereich hinausreicht. Der Balken „Ex.2-5del“ steht für eine große Deletion der Exons 2-5. del: Deletion. dup: Duplikation. ins: Insertion.. Mit roten Kästen sind die in der vorliegenden Arbeit gefundenen Mutationen markiert. (Modifiziert nach Beetz et al. 2008, Human Gene Mutation Database, Stand 01/2013). 
Im Patientenkollektiv der vorliegenden Arbeit konnten eine Splice-Site-Mutation, eine Missense-Mutation und eine Mutation in der regulatorischen 3'UTR nachgewiesen werden.

Bislang wurden 8 verschiedene Splice-Site-Mutationen in REEPl beschrieben (vgl. Tab. 8, HGMD, http://www.biobase-international.com, 22.01.2013), was darauf hindeutet, dass sie relativ häufig auftreten. Sie können sowohl die Splice-Donor-als auch die Splice-AkzeptorStelle betreffen.

Tab. 8: Übersicht über die bisher beschriebenen Splice-Site-Mutationen. (HGMD, http://www.biobase-international.com, 22.01.2013)

\begin{tabular}{|l|c|l|l|}
\hline DNA-Veränderung & Exon & \multicolumn{1}{|c|}{ Seite } & \multicolumn{1}{c|}{ Literatur } \\
\hline c. $105+6 T>C$ & 2 & Splice-Donor & Schlang et al. (2008) \\
\hline c. $106-4 A>G$ & 2 & Splice- Akzeptor & Goizet et al. (2011) \\
\hline c. $183-2 A>G$ & 3 & Splice- Akzeptor & Züchner et al. (2006) \\
\hline c.303G $>$ A & 4 & Splice-Donor & Beetz et al. (2008) \\
\hline c.366G $>$ T & 5 & Splice-Donor & Goizet et al. (2011) \\
\hline c. $417+1 G>A$ & 5 & Splice-Donor & Liu et al. (2009) \\
\hline c.417+1G $>$ T & 5 & Splice-Donor & Beetz et al. (2008) \\
\hline c.595G $>$ C & 6 & Splice-Donor & Beetz et al. (2008) \\
\hline
\end{tabular}

Die in der vorliegenden Arbeit beschriebene Splice-Site-Mutation c.183-2A $>$ G wurde bereits in der Arbeit von Züchner et al. (2006) beschrieben (vgl. Tab. 8). Die Veränderung war bei 365 untersuchten Kontrollindividuen (730 Chromosomen) nicht $\mathrm{zu}$ finden. Sie liegt im Bereich der 5'-Splice-Akzeptor-Stelle vor Exon 4 und reduziert nach NNSPLICE-Vorhersage (eine Software zur Analyse möglicher Auswirkungen einer Splice-Site-Mutation) die SpliceEffizienz von 99\% auf $0 \%$ (http://www.fruitfly.org/seq tools/splice.html, 22.01.2013). Dadurch kommt es zu einem Frameshift und schließlich zu einem vorzeitigen Stopp-Codon (Züchner et al. 2006). Um Rückschlüsse der Mutationsauswirkungen auf Proteinebene in vitro ziehen zu können, ist die Isolation und Sequenzierung der mRNA notwendig. Da REEP1 jedoch nicht in Leukozyten exprimiert wird und die Untersuchung möglicher Mutationsauswirkungen nicht die Durchführung einer Muskel- oder Nervenbiopsie rechtfertigt, liegen bislang keine derartigen Untersuchungsergebnisse an humanem Gewebe vor (Züchner et al. 2006). Hier wären Expressionsanalysen an RNA aus nicht- bzw. minimalinvasiv zu gewinnenden Patienten-Proben wünschenswert.

Missense- und Nonsense-Mutationen stellen die zweithäufigste Art molekulargenetischer Veränderungen in REEP1 dar. Es konnten bislang 11 verschiedene Mutationen dieser Art nachgewiesen werden (vgl. Tab. 9, HGMD, http://www.biobase-international.com, 
22.01.2013). Missense-Mutationen führen zum Austausch einer Aminosäure. NonsenseMutationen hingegen führen zur Generierung eines vorzeitigen Stopp-Codons. In der Patientenkohorte der vorliegenden Arbeit fand sich die neue Missense-Mutation c.605A>G. Der Basenaustausch $A>G$ an Position 605 führt zur Disruption des Stopp-Codons in Exon 7 und somit zur Verlängerung der Aminosäuresequenz. Das alternative Stopp-Codon befindet sich 54 Triplets downstream, an Position 256 des Proteins. Durch die veränderte Proteinlänge ist anzunehmen, dass sich die Sekundär- und Tertiärstruktur von REEP1 verändern.

Tab. 9: Übersicht über die bislang beschriebenen Missense und Nonsense-Mutationen in REEP1 (HGMD, http://www.biobase-international.com, 22.01.2013).

\begin{tabular}{|c|c|c|}
\hline \multicolumn{2}{|c|}{ Veränderung auf } & \multirow[b]{2}{*}{ Literatur } \\
\hline cDNA-Ebene & Protein-Ebene & \\
\hline c. $56 \mathrm{C}>\mathrm{T}$ & p.Pro19Leu & Goizet et al. (2011) \\
\hline c. $56 \mathrm{C}>\mathrm{G}$ & p.Pro19Arg & Beetz et al. (2008) \\
\hline c. $59 \mathrm{C}>\mathrm{A}$ & p.Ala20Glu & Züchner et al. (2006) \\
\hline c. $68 \mathrm{C}>\mathrm{T}$ & p.Ser23Phe & Goizet et al. (2011) \\
\hline c. $124 \mathrm{~T}>\mathrm{C}$ & p.Trp42Arg & Goizet et al. (2011) \\
\hline c. $164 \mathrm{C}>\mathrm{A}$ & p.Thr55Lys & Schlang et al. (2008) \\
\hline c. $166 \mathrm{G}>\mathrm{A}$ & p.Asp56Asn & Goizet et al. (2011) \\
\hline c. $198 \mathrm{~T}>\mathrm{G}$ & p. Tyr66Stopp & Goizet et al. (2011) \\
\hline c.320T $>C$ & p.Leu107Pro & Schlang et al. (2008) \\
\hline c. $337 \mathrm{C}>\mathrm{T}$ & p.Arg113Stopp & Hewamadduma et al. (2008) \\
\hline c. $345 \mathrm{C}>\mathrm{A}$ & p.Tyr115Stopp & Schlang et al. (2008) \\
\hline
\end{tabular}

Die dritte gefundene Mutation c.606+14C $>$ T betrifft die 3'UTR. Veränderungen in diesem regulatorischen Bereich des REEP1-Gens scheinen eine relativ häufige Ursache für SPG31 zu sein, da sowohl Züchner et al. (2006) als auch Beetz et al. (2008) Patienten mit dieser Art von Mutationen beschrieben haben (vgl. Tab. 10). In 1000 gesunden Kontrollindividuen fanden sich keine vergleichbaren Veränderungen. Es konnte experimentell bislang jedoch noch nicht gezeigt werden, dass diese Mutationen tatsächlich einen Effekt auf die Proteinbiosynthese haben und somit krankheitsverursachend sind. 
Tab. 10: Übersicht über die bisher beschriebenen Mutationen in der regualtorisch wichtigen 3' untranslatierten Region des REEP1-Gens. (HGMD, http://www.biobase-international.com, 22.01.2013).

\begin{tabular}{|l|c|l|}
\hline \multicolumn{1}{|c|}{ DNA-Veränderung } & Exon & \multicolumn{1}{c|}{ Literatur } \\
\hline c. $606+14 C>T$ & 6 & Beetz et al. (2008) \\
\hline c.606+43G $>$ T & 6 & Hewamadduma et al. (2008) \\
\hline c. $606+50 G>A$ & 6 & Züchner et al. (2006) \\
\hline
\end{tabular}

Mittels Multiplex Ligation-dependent Probe Amplification können große genomische Rearrangements (LGR; Deletionen und Duplikationen) detektiert werden. Wie die bisherigen Veröffentlichungen zeigen, ist die Inzidenz großer Deletionen und Duplikationen im REEP1Gen eher gering. Es wurden eine Duplikation der Exone 2-7, eine Deletion der Exone 2-5 sowie jeweils eine isolierte Deletion von Exon 2 bzw. Exon 3 beschrieben (vgl. Tab. 11, HGMD, http://www.biobase-international.com, 22.01.2013). Diese geringe Inzidenz könnte die Ursache dafür sein, dass im Patientenkollektiv der vorliegenden Arbeit keine Veränderungen mittels MLPA detektiert werden konnten. Es sind also weitere Studien an größeren Patientenkohorten nötig.

Tab. 11: Übersicht über die bisher beschriebenen großen genomischen Rearrangements. HGMD, http://www.biobase-international.com, 22.01.2013.

\begin{tabular}{|l|c|l|}
\hline \multicolumn{1}{|c|}{ DNA-Veränderung } & Exon & \multicolumn{1}{c|}{ Literatur } \\
\hline Deletion & 2 & Goizet et al. (2011) \\
\hline Deletion & $2-5$ & Battini et al. (2011) \\
\hline Duplikation & $2-7$ & Beetz et al. (2008) \\
\hline Deletion & 3 & Goizet et al. (2011) \\
\hline
\end{tabular}

Zusammenfassend lässt sich feststellen, dass es im REEP1-Gen ein großes Spektrum verschiedener genetischer Veränderungen gibt. Die meisten Mutationen führen zur verminderten Bildung von physiologischem REEP1. Bei autosomal dominantem Erbgang impliziert dies einen Funktionsverlust von REEP1 durch Haploinsuffizienz (Beetz et al. 2008).

\subsection{Klinische Merkmale der Hereditären Spastischen Paraplegie Typ 31}

Patienten mit Spastischer Paraplegie Typ 31 zeigen vorwiegend einen unkomplizierten Phänotyp (Züchner et al. 2006). Im Jahr 2008 wurde bei einer Familie neben der spastischen 
Paraplegie eine Amyotrophie beschrieben, sodass bei der dort gefundenen SPG31-Mutation von einem komplizierten Phänotyp ausgegangen wurde (Hewamadduma et al. 2008). Auch Beetz et al. (2008) beschrieben zwei Patienten mit distaler Amyotrophie, klassifizierten diese jedoch als unkomplizierte HSP-Patienten. Ein mögliches Ziel für weitere Studien wäre die Etablierung eines eindeutigen Klassifizierungssystems.

Bei der Indexpatientin 28103 und ihrem Bruder zeigt sich ein unkomplizierter Phänotyp, aber mit interindividuell unterschiedlich starker Ausprägung von Gangstörung und begleitenden Symptomen. So ist die Indexpatientin im Erwachsenenalter noch ohne Gehhilfe mobil, während ihr Bruder schon seit längerer Zeit auf einen Rollstuhl angewiesen ist (vgl. Abb. 9 und Kapitel 3.1.2.2). Die von Züchner et al. (2006) beschriebenen Patienten mit derselben Mutation zeigen, neben der Gangstörung mit Schwäche der unteren Extremitäten, Kloni des Sprunggelenks und eine milde Skoliose. Wie auch bei den Betroffenen der Familie unserer Indexpatientin findet sich ein positiver Babinski-Reflex. Eine genauere Genotyp-PhänotypKorrelation ist aufgrund der geringen Anzahl Betroffener mit derselben Mutation nicht möglich.

Auch die Mutation c.606 $+14 \mathrm{C}>\mathrm{T}$ ist bereits beschrieben worden. $\mathrm{Zu}$ dem von Beetz et al. (2008) beschriebenen Patienten gibt es jedoch keine detaillierten klinischen Angaben. Die Betroffenen der Familie 30213 zeigen einen unkomplizierten Phänotyp, jedoch variiert der Schweregrad interindividuell sehr stark. In der III. Generation ist die Gangstörung deutlich ausgeprägter als in der II. Generation (vgl. Abb. 8 und Kapitel 3.1.2.1).

Die Einführung eines einheitlichen Ratingsystems würde es erleichtern, die Patienten miteinander zu vergleichen und eine Genotyp-Phänotyp-Korrelation zu versuchen. Hier würde sich z.B. die Spastic Paraplegia Rating Scale des German Network for Hereditary Movement Disorders (GeNeMove) eignen (s. Tab. 12 im Anhang). Im Rahmen einer neurologischen Untersuchung werden 13 Kriterien bewertet. Dazu gehören z.B. die maximale Gehstrecke, die ohne Pause zurückgelegt werden kann, die Qualität des Gangbildes und das Treppensteigen. Für jedes der Kriterien können maximal vier Punkte vergeben werden. Schwerst betroffene Patienten können maximal 52 Punkte erreichen. So kann der Schweregrad der Erkrankung eingestuft und verglichen werden (Schüle et al. 2006). 


\subsection{Manifestationsalter der Hereditären Spastischen Paraplegie Typ 31}

Wie auch bei anderen Hereditären Spastischen Paraplegien ist das Erkrankungsalter unter den SPG31-Patienten sehr variabel. Die überwiegende Anzahl Betroffener zeigt erste Symptome im Kindes- oder Jugendalter. Bei einigen Patienten konnte die Erstmanifestation jenseits des 30. Lebensjahres dokumentiert werden, sodass eine bimodale Verteilung angenommen wird (Beetz et al. 2008, Hewamadduma et al. 2008, Goizet et al. 2011).

Bei der Indexpatientin 28103 und ihrem Bruder lag der Erkrankungsbeginn in der Kindheit. Der Vater zeigte erst im hohen Erwachsenenalter Symptome einer spastischen Gangstörung (vgl. Abb. 8 und Kapitel 3.1.2.2). Der Indexpatient 30213 sowie seine Schwester erkrankten erst im jungen Erwachsenenalter, wohingegen der Bruder und die Tochter des Indexpatienten bereits im Kindesalter Symptome der Gangstörung zeigten (vgl. Abb. 7 und Kapitel 3.1.2.1).

So deuten diese beiden Stammbäume nicht nur auf eine zweigipflige Verteilung des Manifestationsalters hin, sondern geben auch Hinweise auf eine genetische Antizipation. Tendenziell liegt der Erkrankungsbeginn bei der zweiten und dritten Generation Betroffener eher im jüngeren Lebensalter.

Das Phänomen der genetischen Antizipation ist vor allem bei Erkrankungen mit CAG-RepeatExpansion beschrieben, wie z.B. bei der Chorea Huntington. Durch Zunahme der Wiederholungen eines bestimmten Basen-Triplets erkranken die Patienten von Generation zu Generation in immer früherem Lebensalter (Lo und Hughes 2011).

\subsection{Epidemiologie der Hereditären Spastischen Paraplegie Typ 31}

Zunächst wurde die Häufigkeit von REEP1-Mutationen mit 6,5 Prozent unter allen HSPPatienten sehr hoch geschätzt (Züchner et al. 2006). Die nachfolgenden Publikationen lassen eher auf eine Rate von 2-5\% schließen (Beetz et al. 2008, Goizet et al. 2011). Dennoch sind Mutationen in diesem Gen nach SPG4 und SPG3A als dritthäufigste Ursache für autosomal dominant vererbte spastische Paraplegien anzusehen (Beetz et al. 2008, Hewamadduma et al. 2008). In einer Studie von McCorquodale et al. (2011) fanden sich mit einer Häufigkeit von 5\% sogar mehr Mutationen in REEP1 als in ATL1 (SPG3A).

In der vorliegenden Studie konnten bei 2 Patienten aus einer Kohorte von 64 Personen mit Hereditärer Spastischer Paraplegie Mutationen im REEP1-Gen detektiert werden. Damit liegt die Inzidenz bei 3,13\%. Dies würde sich mit den vorbeschriebenen Inzidenzen decken. Leider 
ist das Studiendesign der anderen Arbeiten nicht einheitlich: Schlang et al. (2008) untersuchten nur Patienten mit unkompliziertem Phänotyp und autosomal dominantem Erbgang. Goizet et al. (2011) legten zusätzlich fest, dass in ihrer Kohorte SPG3A- und SPG4Veränderungen inkl. großer Rearrangements sowie Veränderungen in weiteren ADHSPGenen ausgeschlossen sein sollten.

Da Hereditäre Spastische Paraplegien zu den seltenen Erkrankungen gehören (Definition: Weniger als 5 Betroffenen pro 10000 Einwohner in Europa, vgl. Salvatore et al. 2011) und für die vorliegende Studie strenge Einschlusskriterien gewählt wurden, ergab sich nur eine geringe Zahl von 64 untersuchten Patienten. Es sollten Mutationen in SPG3A und SPG4 ausgeschlossen sein. Außerdem wurden nur Patienten mit familiärer unkomplizierter spastischer Paraplegie eingeschlossen. Bei dieser Studie wurde also außer Acht gelassen, dass auch SPG31-Patienten mit kompliziertem Phänotyp (Hewamadduma et al. 2011) oder sporadischer spastischer Paraplegie (Beetz et al. 2008) beschrieben worden sind. Zur besseren Vergleichbarkeit von Prävalenzen sollten Studien mit einheitlichen Einschlusskriterien durchgeführt werden.

\subsection{Expressionsanalyse von REEP1 in verschiedenen humanen Geweben}

Eine RT-PCR-Analyse verschiedener humaner Gewebe wie Muskel, Rückenmark, Kleinhirn etc. zeigte, dass REEP1 ubiquitär exprimiert wird. In Fibroblasten aus Hautstanzen und Leukozyten des peripheren Blutes konnte jedoch keine REEPl-Expression nachgewiesen werden (Saito et al. 2004, Züchner et al. 2006). Zur näheren Charakterisierung der beschriebenen Splice-Site-Mutationen ist es ethisch nicht gerechtfertigt, den Patienten Nerven-, Muskel- oder Leberbiopsien zuzumuten. Daher wäre es wünschenswert, diese Untersuchungen an leicht zu gewinnendem Material, wie zum Beispiel Körpersekreten oder Haaren, durchführen zu können.

\subsubsection{Mundschleimhaut und Zellen der Speicheldrüsen und -ausführungsgänge}

Die Gewinnung von RNA aus Speichel und Mundschleimhaut ist in den letzten Jahren eine häufig angewandte Technik zur Detektion von Tumoren im Mundraum (Li et al. 2004, Park et al. 2006) und zur Untersuchung des Einflusses inhalativer Noxen auf die Genexpression 
geworden (Spivack et al. 2004).

In den Versuchen der vorliegenden Arbeit konnten keine ausreichenden Mengen RNA aus Speichel isoliert werden, um diese mittels RT-PCR zu vervielfältigen. Mögliche Ursachen könnten eine zu geringe Anzahl vitaler Zellen im Speichel und konsekutiv eine zu geringe RNA-Menge sein. Eines der publizierten Protokolle sah als Ausgangsmaterial für die RNAIsolation den zellfreien Speichel-Überstand nach 30-minütiger Zentrifugation vor (Park et al. 2006). Jedoch konnten dort nur bestimmte mRNAs nachgewiesen werden und es gab interindividuell starke Schwankungen der mRNA-Level. Bei den in der vorliegenden Arbeit verwendeten TriFast- und RNeasy Saliva Protect-Protokollen wurde das Zellpellet eingesetzt (vgl. Kap. 2.2.2.2).

Bei den Zellen im Speichel handelt es sich um verschiedene Epithelzellen, die sich im Rahmen der Apoptose durch Auflösung der Zellverbindungen aus dem Epithelverband lösen. Ein physiologischer Prozess im Rahmen des programmierten Zelltodes ist auch die Degeneration der RNA, sodass häufig nur noch RNA-Fragmente nachweisbar sind (Spivack et al. 2004, Park et al. 2010). Um vitale Zellen der Mundschleimhaut abzuschilfern und so die Zellausbeute zu erhöhen, setzten Spivack et al. (2004) kleine Bürsten ein. In der vorliegenden Arbeit wurden die Zellen mithilfe eines kleinen „Löffels“, der zur Gewinnung von Speichelproben in der Routine-Diagnostik eingesetzt wird, abgeschilfert. Ein möglicher Vorteil der Bürsten könnte sein, dass die abgeschilferten Zellen daran haften und somit direkt in ein Reagenzgefäß überführt werden können.

Der physiologische RNA-Abbau erfolgt durch ubiquitär vorkommende und sehr umweltresistente RNasen (Marshall et al. 2008). Durch Behandlung von Arbeitsgeräten und Oberflächen mit speziellen Chemikalien (z.B. RNase away) können diese degradiert werden. Trotzdem ist eine weitere Reduktion der RNA-Ausbeute durch Kontamination mit RNasen denkbar. Eine weitere Fehlerquelle könnte die Behandlung der RNA mit DNase A im RNeasy Saliva Protect-Protokoll sein. Die DNase A vermindert bei vollständiger Degeneration genomischer DNA nachweislich die RNA-Ausbeute (Huang et al. 1996). Beim TriFastProtokoll könnte der physiologisch hohe Bikarbonat-Gehalt im Speichel (Speckmann et al. 2008) einen Einfluss auf die RNA-Qualität haben, da es laut Herstellerinformationen Interaktionen des Reagenzes mit Puffersubstanzen gibt (http://www.peqlab.com, 18.07.2012). 


\subsubsection{Urothelzellen und Epithelien der ableitenden Harnwege aus Spontanurin}

Die Untersuchung von RNA aus Urin ist eine mögliche Screeningmethode zur Früherkennung von Blasenkrebs (Weikert et al. 2005, Hanke et al. 2007, Wadhwa et al. 2012) und kann auch zur Funktionsdiagnostik allogener Nierentransplantate eingesetzt werden (Li et al. 2001). In den Versuchen der vorliegenden Arbeit konnten keine ausreichenden Mengen RNA aus den Urinproben isoliert werden.

Eine denkbare Ursache dafür ist, dass für die Isolation in der Literatur überwiegend kommerzielle Kits verwendet wurden (Li et al. 2001, Hanke et al. 2007). Die Verwendung des TriFast-Reagenz zur RNA-Gewinnung ist nicht beschrieben worden. Im Urin sind neben Zellen auch Giftstoffe und Stoffwechselendprodukte enthalten. Diese Inhaltsstoffe könnten durch Interaktion mit den verwendeten Chemikalien einen Einfluss auf die RNA-Ausbeute haben. So kann laut Herstellerinformationen z.B. ein alkalischer Urin-pH zu einer geringeren RNA-Ausbeute und DNA-Kontamination bei Verwendung des TriFast-Reagenzes führen (http://www.peqlab.com, 18.07.2012). Die Isolierung erfolgte in den meisten Fällen aus dem Zellpellet des Urins. Dieses besteht aus abgeschilferten Zellen der Niere, der Blase und der ableitenden Harnwege. Bei Tumorerkrankungen (v.a. Urothelkarzinomen) werden u.a. im Rahmen der Metastasierung viele vitale Zellen abgeschilfert, eine Tatsache, die man sich bei der Urin-Zytologie zunutze macht (Hautmann und Huland 2006, Wadhawa et al. 2012). Aufgrund der größeren Zellmenge lässt sich schlussfolgern, dass bei Tumorerkrankungen eine deutlich größere RNA-Ausbeute zu erwarten ist. Hanke et al. (2007) isolierten mit gutem Erfolg RNA aus zellfreiem Urin. Es wurde davon ausgegangen, dass im Rahmen des programmierten Zelltodes kleine Apoptose-Körperchen entstehen, die sich aus dem Zellverband lösen und mit dem Urin ausgeschieden werden. In diesen Körperchen soll die RNA vor Abbau durch Urin-RNasen geschützt sein. Einen zusätzlichen positiven Einfluss schien die Behandlung des Urins mit Guanidinthiozyanat (GTC) unmittelbar nach Probengewinnung zu haben. Hierdurch werden RNA-degradierende Enzyme inaktiviert. Hanke et al. (2007) führten ebenfalls Genexpressions-Studien anhand von Urin-RNA durch. Sie stellten fest, dass nicht nur RNA-Menge und -Qualität den Erfolg der Experimente beeinflussten, sondern auch die Stabilität der PCR-Amplifikate.

Für weiterführende Studien ist festzuhalten, dass eine $\mathrm{pH}-\mathrm{Metrie}$ des verwendeten Urins vor RNA-Isolation sinnvoll erscheint. Der pH-Wert sollte gemäß Herstellerempfehlungen für das 
verwendete Reaktionssystem eingestellt werden. Da RNA sehr instabil ist, ist es unabdingbar, einen weiteren Verlust durch RNA-degradierende Enzyme zu verhindern. Eine Möglichkeit ist die Behandlung der Proben mit GTC, sofern dieses nicht mit den Chemikalien für die RNAIsolation interferiert. Um die RNA-Ausbeute zu erhöhen, scheint es ebenfalls sinnvoll zu sein, kommerzielle Kits zu verwenden, mit denen auch kleinste RNA-Mengen aufgereinigt werden können.

Weitere Studien müssen zeigen, ob die RNA-Isolation aus dem Zellpellet oder aus zellfreiem Urin zu einer höheren RNA-Ausbeute führt. Notwendig erscheint die Entwicklung und Veröffentlichung eines standardisierten Protokolls zur RNA-Isolation, um Expressionsanalysen an Urothelzellen und Zellen der ableitenden Harnwege verlässlicher und vergleichbarer zu machen.

\subsubsection{Haarwurzeln}

In der Forensik wird zur Genotypisierung routinemäßig DNA aus Haaren gewonnen (Szabo et al. 2011). Vor allem die Isolation mitochondrialer DNA (mtDNA) aus dem Haarschaft ist ein etabliertes Verfahren (Opel et al. 2008). Auch einzelne Protokolle zur Isolation von RNA und anschließender Expressionsanalyse aus Haarwurzeln waren bei einer Literaturrecherche zu finden (Fujikawa et al. 2012). In den durchgeführten Versuchen im Rahmen dieser Arbeit war es möglich, cDNA-Amplifikate nach Reverser Transkription und PCR im Agarose-Gel nachzuweisen. Eine Sequenzanalyse der cDNA zeigte, dass es sich tatsächlich um die SPG31cDNA handelte.

Die Ergebnisse der vorliegenden Arbeit deuten darauf hin, dass Haarwurzeln zur Charakterisierung von Splice-Site-Mutationen in SPG31 verwendet werden können. Jedoch ist das Verfahren der RNA-Isolation noch nicht ausreichend standardisiert, die cDNA-Menge war häufig sehr gering. Eine Ursache könnte die sehr geringe Anzahl vitaler Zellen sein, die lediglich im Bereich des Haarbulbus lokalisiert sind. Der Haarschaft hingegen besteht überwiegend aus verhornten Keratinozyten, die nach der Apoptose nur noch Reste von Nukleus und Organellen enthalten. Die Isolation von DNA-Bruchstücken aus Haarschäften wird in der Forensik zur Genotypisierung verwendet. Ein RNA-Nachweis gelingt hieraus nicht mehr. (Linch et al. 2001, Fritsch 2004, Linch 2009, Szabo et al. 2011)

Da die Haardicke von der Anzahl der Matrixzellen abhängt (Fritsch 2004), ist umgekehrt 
anzunehmen, dass bei der Verwendung dickerer Haare für die RNA-Isolation mehr vitale Keratinozyten im Haarbalg zu finden sind als bei dünneren Haaren. Dies würde erklären, warum die Ergebnisse bei der Verwendung der gleichen Anzahl mikroskopisch dickerer Haare bzw. größerer Haarwurzeln reproduzierbar besser waren. Es lässt sich auch vermuten, dass der Einsatz einer größeren Anzahl Haarwurzeln bei dünnen Haaren bessere Ergebnisse bringt.

Eine weitere Möglichkeit, die RNA-Ausbeute zu erhöhen, wäre die Verwendung spezieller Kits zur Isolation auch sehr geringer RNA-Mengen, wie z.B. von Fujikawa et al. (2012) beschrieben.

\subsubsection{Perspektiven}

Bislang konnte nur mithilfe von Computerprogrammen vorhergesagt werden, ob Splice-SiteMutationen in SPG31 krankheitsverursachend sind, ein experimenteller Nachweis wurde nicht beschrieben. Aufgrund der Untersuchungen im Rahmen der vorliegenden Arbeit ist anzunehmen, dass REEP1 in Haarwurzeln exprimiert wird. Anhand von mRNA aus PatientenHaarwurzeln bzw. der daraus synthetisierten cDNA könnte der Effekt von Splice-SiteMutationen mittels Sequenzanalyse untersucht werden. Hier wäre interessant zu sehen, ob es durch unvollständiges Splicen zu Exon-Skipping oder zur Intron-Retention kommt.

Exon-Skipping würde bedeuten, dass die Splice-Stelle am Intron-Exon-Übergang (SpliceAkzeptorstelle) nicht erkannt wird und somit das gesamte Exon inklusive nachfolgendem Intron übersprungen würde. Eine Intron-Retention hingegen entsteht durch Nicht-Erkennen einer Splice-Donorstelle (Übergang Exon-Intron). Das zu entfernende Intron bleibt in der mRNA-Sequenz enthalten (vgl. Abb. 28). Beide Veränderungen haben Auswirkungen auf die spätere Proteinsequenz. Im Falle einer Intron-Retention werden bei der Translation zusätzliche Aminosäuren eingebaut. Beim Exon-Skipping fehlen Aminosäuren. Bei beiden Phänomenen ist durch Verschiebung des Leserasters die Bildung vorzeitiger Stopp-Codons möglich. 


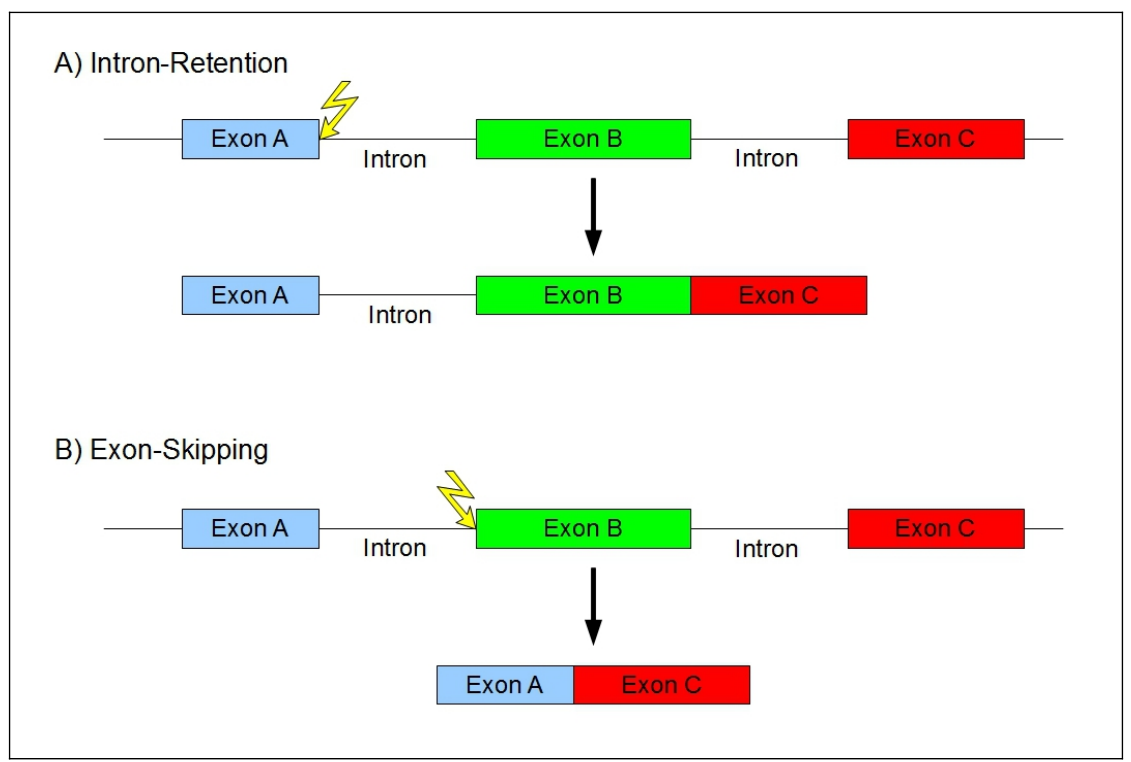

Abb. 28: Mögliche Effekte einer Splice-Site-Mutation.

A) Durch Nicht-Erkennen der Splice-Donorstelle bleibt das Intron zwischen Exon A und B nach dem Splice-Vorgang in der mRNA-Sequenz enthalten. B) Durch Mutationen im Bereich der SpliceAkzeptorstelle kann es zum Exon-Skipping kommen. Exon B fehlt in der reifen $m R N A$.

Massiv veränderte mRNA-Sequenzen können mittels Nonsense-Mediated Decay vor Beginn der Proteinbiosynthese abgebaut werden und so zu einem verminderten mRNA-Level führen (Chang et al. 2007).

Das Verfahren der RNA-Isolation aus Haaren muss noch weiter validiert und standardisiert werden, um die RNA-Ausbeute zu erhöhen. Dann kann auch Patientenmaterial untersucht werden und experimentell nachgewiesen werden, ob die Vorhersage des Computerprogramms NNSPLICE stimmt und es bei der Mutation c-183-2A $>$ G durch Veränderung der SpliceAkzeptorstelle zum Exon-Skipping kommt und welche Auswirkungen dies auf die mRNA und die Proteinbiosynthese hat.

\subsection{Rolle von Mutationen im Bereich von miRNA-Bindestellen in der Pathogenese der Hereditären Spastischen Paraplegie 31}

Zunächst soll ein kurzer Überblick über miRNAs und ihre Rolle bei der Entstehung von Erkrankungen gegeben werden. 


\subsubsection{Definition von miRNAs}

Mikro-RNAs sind kurze, einzelsträngige und nicht-codierende RNA-Sequenzen, die der posttranskriptionellen Regulation der Gen-Expression dienen. Sie haben u.a. einen Einfluss auf die Proliferation, Differenzierung und Apoptose von Zellen. Reife miRNAs befinden sich im Zytoplasma und können sich an partiell komplementäre mRNAs anlagern. Sie stellen eine Verbindung zum RNA-induced silencing complex (RISC) her. So kann einerseits durch direkte Endonuklease-Aktivität, andererseits durch Deadenylierung und Exonuklease-Aktivität die mRNA degradiert und in der Folge die Translation verhindert werden (Lee et al. 2002, Bartel 2004, Doench und Sharp 2004).

Es wurden jedoch auch einige wenige miRNAs beschrieben, die die Translation hochregulieren, wie z.B miR-373 bei der Expression des Genes für E-Cadherin (Place et al. 2008, Vasudevan et al. 2007).

\subsubsection{Entdeckung von miRNAs und ihren Zielsequenzen}

Die erste miRNA lin-4 wurde 1993 in dem Fadenwurm Caenorhabditis elegans entdeckt (Lee et al. 1993). Sie spielt eine Rolle bei der Entwicklung vom ersten zum zweiten Larvenstadium (Olsen und Ambros 1999). Erst Jahre später wurde let-7, eine weitere miRNA, in Caenorhabditis elegans entdeckt. Auch diese hat durch Unterdrückung der Expression von Proteinen, die in adulten Fadenwürmern nachweisbar sind, einen Einfluss auf die LarvenEntwicklung (Slack et al. 2000). Diese Entdeckungen legten den Grundstein zur Identifikation vieler weiterer miRNAs in Pflanzen, Tieren und beim Menschen. Bislang wurden mehr als 2000 verschiedene miRNA-Sequenzen allein im humanen Genom entdeckt (http://www.mirbase.org, 23.01.2013) und es wird davon ausgegangen, dass 30-50\% aller Protein-codierenden Gene durch miRNAs reguliert werden (Bentwich et al. 2005, Rajewsky 2006, Li et al. 2008, Krol et al. 2010). Allerdings ist die genaue Interaktion zwischen miRNA und Zielsequenz weiterhin unklar. Es gibt verschiedene Hypothesen, welche Kriterien eine mRNA-3'UTR erfüllen muss, um von einer miRNA als Zielsequenz erkannt zu werden (Didiano und Hobert 2008, Thomson et al. 2011, Pasquinelli 2012). Es konnte mehrfach gezeigt werden, dass perfekte Komplementarität kein Garant für eine posttranskriptionelle Regulation durch miRNAs ist (Vella et al. 2004a, Vella et al. 2004b, Didiano und Hobert 2006). 


\subsubsection{Biogenese und Funktion von miRNAs}

Reife miRNAs sind 20-22 nt lange RNA-Sequenzen. Die Vorstufen reifer miRNAs werden als primary precursor miRNAs (pri-miRNA) bezeichnet und sind bis zu einer Kilobase lang. Wie auch in Abbildung $29 \mathrm{zu}$ sehen ist, können diese pri-miRNAs nach Transkription und Translation aus Introns (= Mirtrons) Protein-codierender Gene (= Host Gene) entstehen (Aravin et al. 2003, Lagos-Quintana et al. 2003, Lim et al. 2003, Ladewig et al. 2012). Weitere Möglichkeiten sind die Synthese durch die RNA-Polymerase II nach Transkription eigenständiger Gene oder anhand von miRNA-Cluster-Regionen (Lagos-Quintana et al. 2001, Lee und Ambros 2001). Zur weiteren Prozessierung dieser RNA-Fragmente gehören möglicherweise, wie auch bei der mRNA, das Capping und die Polyadenylierung (Kim 2005). Durch Drosha, eine nukleäre RNase III Endonuklease, werden die pri-miRNAs im Nucleus zu ca. $70 \mathrm{nt}$ langen Haarnadel-precursor miRNAs (pre-miRNA) prozessiert (Lee et al. 2003, Han et al. 2004). Eine weitere Möglichkeit der miRNA-Reifung sind Splice-Vorgänge am Spliceosom (Okamura et al. 2007, Ruby et al. 2007, Ladewig et al. 2012). Mittels RanGTP und Exportin-5 werden die miR-Vorstufen aktiv ins Zytoplasma transportiert. Dort werden von der RNase III Dicer imperfekte miRNA/miRNA*-Duplexe gebildet (Hutvágner et al. 2001). Der instabilere sog. Passenger-Strang dieses Komplexes wird degradiert, der andere bildet zusammen mit Argonaut-Proteinen (AGO) den sog. miRNA-induced-silencing-complex (miRISC) (Bartel 2009). Über nahezu perfekte Basenpaarung der miRNA-Nukleotide 2-8 an die mRNA kann dieser Komplex die Translation unterdrücken oder eine Deadenylierung der mRNA bewirken (Lee et al. 2002, Bartel 2004, Kim 2005, Krol et al. 2010). 


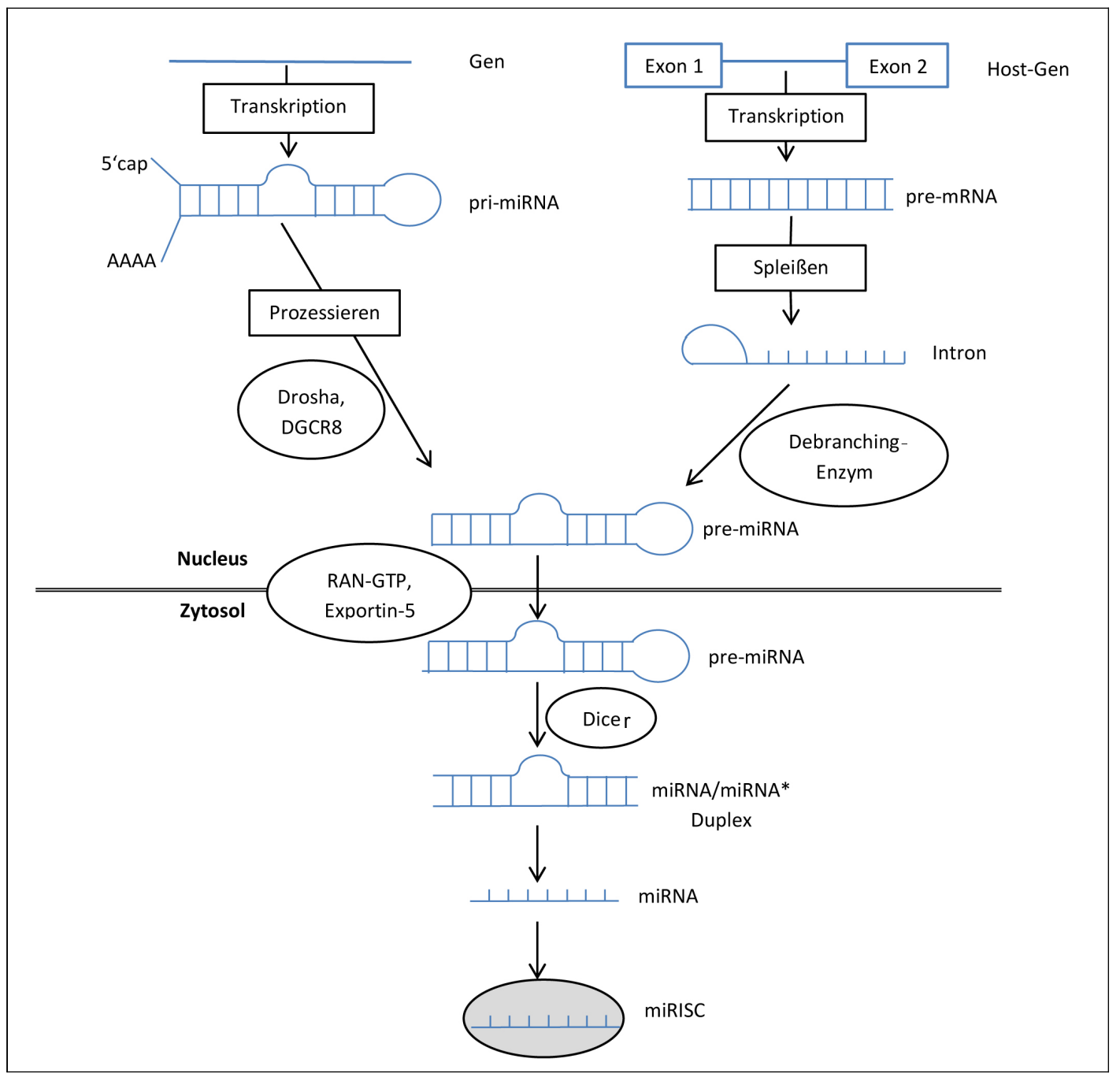

Abb. 29: MicroRNA-Biogenese.

Die miRNA-Vorläufer entstehen aus eigenen Genen oder werden aus Introns proteincodierender Gene prozessiert. Über Transportproteine gelangen sie ins Zytoplasma, wo die Reifung abgeschlossen wird und die miRNAs im Ribonukleoprotein-Komplex ihre Wirkung entfalten können (nach Krol et al. 2010, S. 598).

\subsection{4 miRNAs und ihre Rolle bei der Pathogenese humaner Erkrankungen}

In den letzten Jahren konnte eine Vielzahl von miRNAs entdeckt werden, einige werden ubiquitär exprimiert, andere sind Gewebe-spezifisch. Insbesondere im menschlichen Gehirn finden sich viele verschiedene miRNAs (Lagos-Quintana et al. 2002), die die Proteinexpression herunterregulieren. So ist bei fehlender Regulation eine Beteiligung an der Pathogenese neurodegenerativer Erkrankungen mit Ablagerung toxischer Proteine naheliegend. Bilen et al. (2006) konnten beispielsweise bei Erkrankungen mit Polyglutamin- 
Expansion (z.B. Spinozerebelläre Ataxie, Chorea Huntington) zeigen, dass ein Mangel spezifischer microRNAs die Toxizität der gebildeten pathogenen Proteine dramatisch erhöht. Sowohl bei der Alzheimer-Erkrankung als auch bei Hirntumoren können veränderte Level des Alzheimer-Precursor-Proteins (APP) nachgewiesen werden, welches ebenfalls durch miRNAs reguliert wird. Als integrales Membranprotein ist APP maßgeblich an der Zellproliferation mitbeteiligt und wird z.B. bei Hirntumoren überexprimiert. Außerdem konnte es in den charakteristischen Amyloid-Plaques bei M. Alzheimer nachgewiesen werden (Du und Pertsemlidis 2011, Gascon et al. 2012).

$\mathrm{Zu}$ den Krankheiten mit miRNA-Einfluss gehören auch neuromuskuläre Erkrankungen. Unter Umständen lässt sich die interindividuell unterschiedliche Dystrophin-Expression bei der Duchenne Muskeldystrophie, die Auswirkungen auf den Verlauf hat, durch veränderte miRNA-Regulation erklären (Salvatore et al. 2011). Auch bei der Entstehung kardiovaskulärer Erkrankungen scheinen miRNAs beteiligt zu sein (Li et al. 2008).

Nicht nur bei den Hirntumoren, auch bei Brustkrebs und vielen anderen Tumorentitäten wurden veränderte miRNA-Expressionsmuster festgestellt, die sowohl das Rezidiv-Risiko als auch das klinische Outcome der Patienten beeinflussten (Adams et al. 2007, Li et al. 2008, Hassan 2012).

\subsubsection{Rolle von miRNAs bei der Hereditären Spastischen Paraplegie 31}

Im Bereich der SPG31-3' UTR liegen Sequenzen, die partiell komplementär zu denen der miRNAs miR-140 und miR-691 sind (Züchner et al. 2006, Beetz et al. 2008). Diese potentiellen Zielsequenzen konnten in verschiedenen Spezies, wie z.B. Rindern, Mäusen und Schimpansen, als hochkonserviert nachgewiesen werden (vgl. Abb. 30) (Züchner et al. 2006). Bei Patienten mit Veränderungen in diesen Sequenzen, die typische Symptome einer familiären spastischen Paraplegie aufweisen und bei denen Veränderungen in anderen bekannten HSP-Genen ausgeschlossen werden konnten, liegt der Verdacht nahe, dass miRNAs eine Rolle bei der Pathogenese der spastischen Paraplegie Typ 31 spielen können. Zudem konnten die beschriebenen 3'UTR Veränderungen in 1000 gesunden Kontrollindividuen nicht nachgewiesen werden (Beetz et al. 2008). 


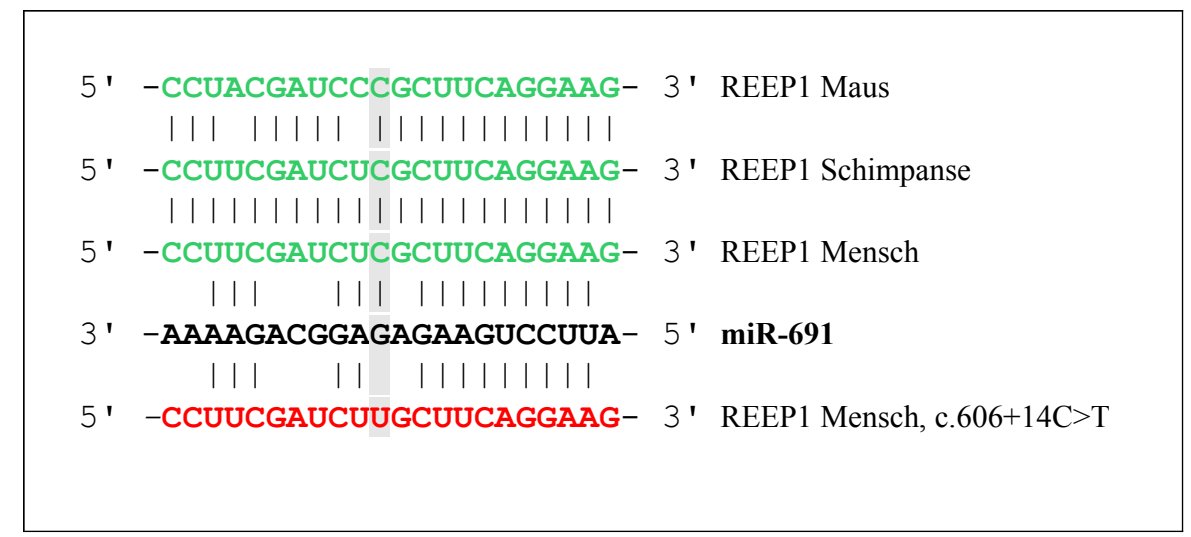

Abb. 30: Hochkonservierte Bindungsstelle an der 3'UTR-Sequenz von REEPI am Beispiel der miRNA-691 bei verschiedenen Spezies.

Grau hinterlegt ist die Stelle, an der sich die Mutation c.606+14 C>T befindet. Es ist zu sehen, dass durch die Mutation eine Watson-Crick-Bindung () zwischen miRNA und mRNA betroffen ist.

Aufgrund der fehlenden Expression des Gens in Leukozyten und Fibroblasten konnten bislang routinemäßig keine quantitativen Expressionsanalysen bei Mutationsträgern durchgeführt werden. Um einen experimentellen Nachweis der Interaktion von mir-691 und der SPG31-3'UTR zu führen und die Einflüsse der Mutation c606+14C $>$ T zu untersuchen, wurde daher ein Luciferase-Assay durchgeführt.

\subsubsection{Assay-System}

Eine Methode zur Untersuchung der posttranskriptionellen Regulation durch miRNAs ist der Luciferase-Assay (Shen et al. 2008). Dazu wird ein Vektor generiert, der u.a. das Gen für das Enzym Luciferase enthält. Luciferase ist ein Enzym, das vielfach zur Quantifizierung der Gen-Expression eingesetzt wird (De Wet et al. 1985, Ow et al. 1986). Downstream dieses Gens im Vektor befindet sich die Multi Cloning Site. In diese wird eine 3'UTR-Sequenz integriert, die die Bindestelle einer bestimmten miRNA enthält. Die Co-Transfektion kompetenter Zellen mit dem Vektor und der entsprechenden miRNA führt zur Synthese einer bestimmten Menge Luciferase. Im Anschluss kann man unter Zusatz aller benötigten Substrate (u.a. Luciferin und ATP) in einem Luminometer die Luciferase-Aktivität (Lichtemission) messen und dadurch auf die Luciferase-Menge rückschließen. Die Abbildung 31 illustriert das beschriebene Vorgehen. 


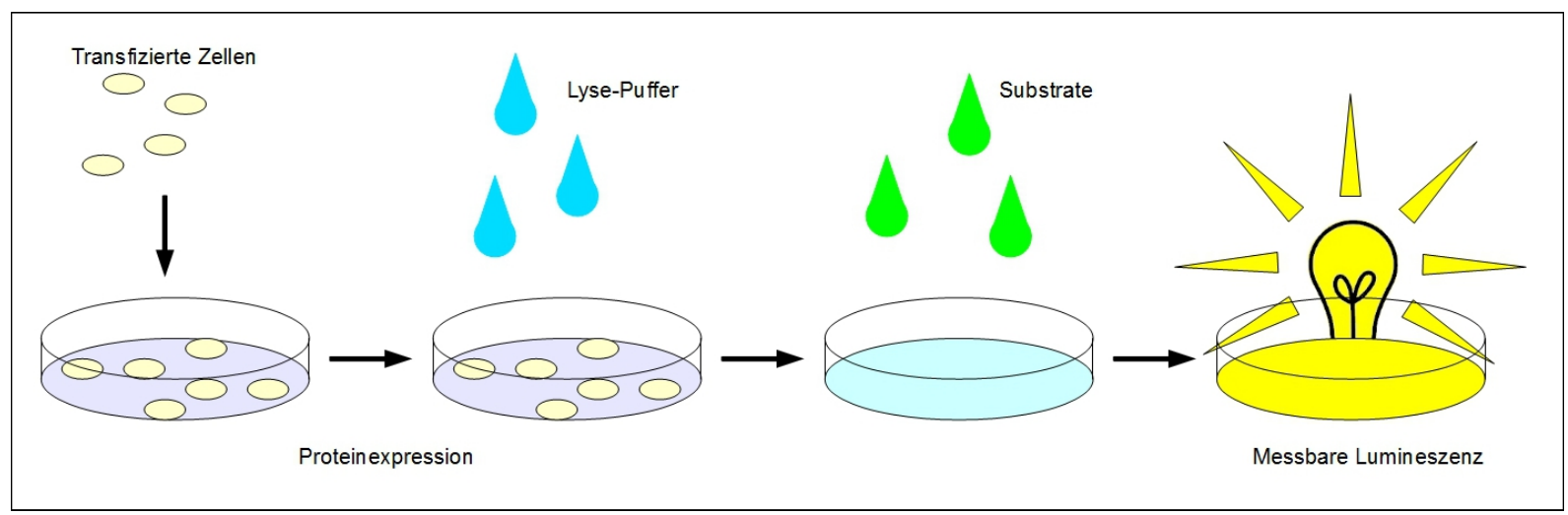

Abb. 31: Schema des Vorgehens beim Luciferase-Assay.

Die Zellen wurden mit der miRNA, dem Luciferase-Reporter und dem $\beta$-Galaktosidase-Vektor cotransfiziert. Nach ausreichender Inkubation zur Proteinexpression wurde Lyse-Puffer hinzugegeben, anschließend wurden die Zellen schockgefroren. Nach dem Auftauen wurden die Substrate zugegeben und die Lumineszenz konnte gemessen werden.

Durch Vergleich des Luciferase-Expressionslevels von Wildtyp-Konstrukten und mutanten Konstrukten lässt sich der Effekt der Mutation im Bereich von miRNA-Bindestellen evaluieren.

\subsubsection{Daten}

Im Rahmen der Etablierung des oben beschriebenen Assay-Systems wurden die Versuchsabläufe und Transfektionsansätze wiederholt umstrukturiert.

Im ersten Versuch (vgl. Abb. 21) zeigte sich eine deutlich höhere Luciferase-Aktivität bei der Wildtyp-Probe mit miR-691 als bei der mit Kontroll-miRNA. Dies entspricht nicht der Erwartung, nämlich dass durch Bindung der miR an die Zielsequenz posttranskriptionell eine Herunterregulation der Transkription erfolgen soll. Die Ergebnisse für die LuciferaseAktivität bei den mutierten Proben entsprechen eher den Erwartungen. Durch Veränderung der Zielsequenz bleibt eine Bindung der miR aus, die Luciferase-Aktivität ist vergleichbar mit der der Kontroll-miRNA-Probe. Allerdings ist bei diesem Versuch die Standardabweichung sehr hoch, sodass die Ergebnisse als nicht zuverlässig anzusehen sind.

Unter der Annahme, dass allein das Vorhandensein einer 3'UTR in der Vektorsequenz einen regulatorischen Einfluss auf die Transkription haben könnte, wurde im zweiten Versuch (vgl. Abb. 22) ein Kontroll-Vektor eingeführt. Hier zeigten sich alle Messwerte auf einem vergleichbaren Niveau, sodass die Versuchsergebnisse kritisch zu betrachten sind. Außerdem 
sind auch hier die Standardabweichungen einzelner Proben sehr groß.

Der dritte Versuch stellte eine Wiederholung des ersten Versuchs dar. Hier zeigte sich bei den Wildtyp-Proben eine sehr geringe Luciferase-Aktivität. Allerdings entsprechen die Ergebnisse tendenziell den Erwartungen Die Luciferase-Expression ist bei der Leerkontrolle (5 und 6) sehr hoch, es gibt keinen regulatorischen Einfluss durch die miRNA und somit auch keine Herunterregulation. Die Lichtemission bei der Probe mit dem mutierten Konstrukt (3 und 4) ist höher als beim Wildtyp, aber geringer als bei der Leerkontrolle. Es scheint also eine Bindung der miRNA an die Zielsequenz und konsekutiv eine gewisse Herunterregulation zu geben. Diese ist jedoch bei mutierter 3'UTR nicht so effektiv wie bei der Wildtyp-Probe. Leider sprechen die sehr geringen Lumineszenz-Werte der Wildtyp-Proben dafür, dass es technische Fehler oder Fehler im Versuchsaufbau gegeben hat. Auch die hohen Standardabweichungen lassen an der Validität dieses Ergebnisses zweifeln.

Die Kontroll-miR (Negative Control 1 Pre-miR) sollte eine miRNA sein, die nicht komplementär zur verwendeten 3'UTR ist und somit keine regulatorische Wirkung entfalten kann. Auffällig ist jedoch, dass die Luciferase-Aktivität der Proben mit Kontroll-miRNA in den meisten Fällen geringer war als die der Proben mit miR-691. Es muss daher davon ausgegangen werden, dass die Kontoll-miR einen Effekt auf die posttranskriptionelle Regulation hat, sodass im vierten Versuch auf den Einsatz dieser miRNA verzichtet wurde. Leider wurde stattdessen keine Leerkontrolle ohne jegliche miRNA mitgeführt. Es zeigte sich eine etwa gleich hohe Luciferase-Aktivtät für Wildtyp- und Leer-Vektor, wohingegen die Werte für die mutante Probe weniger als halb so groß waren. Da sich auch hier sehr große Standardabweichungen zeigten, müssen auch die Ergebnisse dieses Versuchs kritisch betrachtet werden.

Die beiden folgenden Versuche wurden nach dem gleichen Prinzip durchgeführt. Es zeigten sich bei der Auswertung stark voneinander abweichende Ergebnisse, beiden Versuchen gemein waren einzig die hohen Werte für die Standardabweichung.

\subsubsection{Schlussfolgerungen}

Alle Versuche, mittels Luciferase-Assay die Auswirkungen der Mutation in der 3'UTR des SPG31-Gens näher zu charakterisieren, ergaben Messwerte mit sehr hohen Standardabweichungen, sodass eine Wiederholung zum Ausschluss technischer Fehler und zur weiteren Standardisierung des Versuchsaufbaus nötig ist. Während des Entstehungsprozesses dieser Schrift wurde das Assay-System weiter verwendet und es 
konnten Ergebnisse mit akzeptablen Standardabweichungen erzielt werden. Es zeigte sich eine deutlich geringere Luciferase-Expression bei der mutierten Probe als bei der WildtypProbe (Rousseau 2010). Bei Zugrundelegen der überwiegend beobachteten Funktion von miRNAs, der posttranskriptionellen Repression, wäre dies entgegen den Erwartungen. Es passt jedoch zum vorhergesagten Pathomechanismus der Haploinsuffizienz bei der Spastischen Paraplegie vom Typ 31 (Züchner et al. 2006).

In allen Versuchen wurde eine Normalisierung gegen $\beta$-Galaktosidase vorgenommen. Die emittierte Lumineszenz beruht auf einem völlig anderen Reaktionsprinzip, sodass die Messwerte für die beiden Reaktionen sehr unterschiedlich ausfielen. Des Weiteren gestaltete sich die $\beta$-Galaktosidase-Messung sehr zeitintensiv (Inkubation während der Messung für eine Stunde). Da die Proben während dieser Zeit bei Raumtemperatur gelagert wurden, ist eine Degradierung gut möglich. Eine Normalisierung gegen ein anderes Vektorsystem könnte hilfreich sein. Hier besteht die Möglichkeit, einen dualen Luciferase-Assay zu verwenden (Johnson et al. 2005). Die Luciferase der Seefeder Renilla emittiert blaues Licht und benötigt andere Substrate als die Leuchtkäfer-Luciferase. Es wird zunächst die Lichtemission der Firefly-Luciferase gemessen. Nach Zugabe eines Stopp-Reagenzes, das zusätzlich die RenillaSubstrate enthält, wird wieder die Lumineszenz gemessen. Neben der Zeitersparnis wäre ein weiterer Vorteil, dass es keine Verfälschung durch mögliche Verteilungsunterschiede bei der Aufteilung der Proben auf verschiedene Messplatten gibt. Allerdings ist damit zu rechnen, dass sich die Hintergrundaktivität erhöht, wenn die erste Luciferase noch nicht vollständig deaktiviert ist und die Aktivität der zweiten Luciferase gemessen wird.

Neben den technischen Voraussetzungen muss weiterhin diskutiert werden, ob die Vorhersage zutrifft, dass die miR-691 eine Rolle bei der Entstehung der spastischen Paraplegie spielt. Bislang gelang kein experimenteller Nachweis des Einflusses dieser speziellen miRNA auf die posttranskriptionelle Regulation in SPG31. Weiterhin ist unklar, welche Kriterien eine 3'UTR-Sequenz erfüllen muss, um von einer miRNA als Zielsequenz erkannt zu werden (Brendle et al. 2008, Didiano und Hobert 2008). Bei der computergestützten Untersuchung von 3'UTR-Sequenzen auf mögliche miRNA-Zielsequenzen muss derzeit von einer 20\%-igen Rate falsch-positiver Ergebnisse ausgegangen werden (Li et al. 2008).

Formal muss auch die Hypothese, dass die mangelnde Komplementarität der miRNA zu einer geringeren Affinität zur Zielsequenz führt und dadurch keine ausreichende posttranskriptionelle Herunterregulation der Translation stattfindet, in Frage gestellt werden. Bei der Pathogenese der spastischen Paraplegie 31 wird eine Haploinsuffizienz angenommen, die zum Loss of function-Phänomen führt. Züchner et al. (2006) vermuteten bereits, dass 
Mutationen in der 3'UTR supressive Effekte der miRNAs fördern und somit zu weniger REEP1-Protein führen könnten. Würde eine posttrankriptionelle Downregulation ausbleiben, käme es jedoch zur vermehrten Translation und somit zur Akkumulation von REEP1 in der Zelle. Es würde zum Gain of function-Phänomen kommen.

\subsubsection{Perspektiven}

Das Prinzip des Luciferase-Assays kann zur Untersuchung des Einflusses von miRNAs auf die posttranskriptionelle Regulation der Genexpression eingesetzt werden. Da das System jedoch störanfällig ist, ist eine weitere Standardisierung durch Wiederholen der Versuche unter optimalen Bedingungen und Elimination möglicher Fehlerquellen nötig. Nach weiterer Standardisierung des Verfahrens kann es zur Evaluation weiterer Mutationen im Bereich konservierter miRNA-Bindestellen sowohl in der 3'UTR als auch in der 5'UTR des REEPIGens eingesetzt werden. 


\section{Zusammenfassung}

Der Begriff der Hereditären Spastischen Paraplegien umschreibt eine Gruppe seltener, klinisch und genetisch heterogener Erkrankungen. Es sind mittlerweile mehr als 48 verschiedene Gene bekannt, deren Veränderungen zu diesem Krankheitsbild führen. Eines dieser Gene ist das REEP1-Gen (SPG31). Mutationen in diesem Gen werden mit einer Häufigkeit von 2-6\% als dritthäufigste Ursache autosomal dominant vererbter spastischer Paraplegien angesehen.

Im Rahmen dieser Arbeit wurde eine Studie mit 64 nicht-verwandten Patienten mit autosomal dominanter spastischer Paraplegie nach Ausschluss von Mutationen in den beiden am häufigsten betroffenen Gene ( $S P G 4$ und $S P G 3 A$ ) durchgeführt. Bei zwei Patienten konnten insgesamt drei verschiedene genetische Veränderungen nachgewiesen werden. Mit einer Häufigkeit von 3,13\% konnte die beschriebene Inzidenzrate bestätigt werden. Wie auch in der Literatur zeigte sich im Patientenkollektiv der vorliegenden Arbeit ein Beginn der Erkrankung im Kindes- und Jugendalter. Es konnten eine Splice-Site-Mutation am Übergang Intron-Exon 4, eine Missense-Mutation mit Affektion eines Stopp-Codons und eine Mutation in der regulatorischen 3'UTR detektiert werden. Zwei dieser Veränderungen sind bereits beschrieben worden. Eine exakte Genotyp-Phänotyp-Korrelation ist aufgrund der geringen Anzahl von Patienten mit derselben Mutation jedoch noch nicht möglich.

Zur Untersuchung des Effekts von Splice-Site-Mutationen wurden Expressionsanalysen an verschiedenen, nicht-invasiv zu gewinnenden, humanen Materialien durchgeführt. Es zeigte sich, dass Haarwurzeln zur Isolation von RNA gut geeignet sind und REEP I-mRNA in diesen nachweisbar ist. Vor Durchführung von Patientenstudien muss das Verfahren jedoch weiter standardisiert werden.

Zur Untersuchung des Effekts von 3'UTR-Mutationen in SPG31 wurde im Rahmen dieser Arbeit ein Luciferase-Assay etabliert. Es zeigten sich Hinweise dafür, dass durch die Mutation die Translation verstärkt supprimiert wird und es somit zum vorhergesagten Loss of functionPhänomen kommt. Hier sind jedoch eine weitere Standardisierung des Versuchsprotokolls und Beseitigung möglicher technischer Fehler nötig, um verlässliche Aussagen zur Auswirkung von 3'UTR-Veränderungen im Bereich von miRNA-Bindestellen bei der spastischen Paraplegie Typ 31 treffen zu können. 
Auf dem Gebiet der miRNA-Forschung allgemein sind weitere Studien nötig, um die genauen Mechanismen zu verstehen, die zur Zielsequenzfindung von miRNAs führen. So kann geklärt werden, ob die Bindung von miR-691 überhaupt an der Pathogenese der SPG31 beteiligt ist.

Weiterhin besteht viel Klärungsbedarf: Die Funktion von REEP1 ist noch nicht abschließend geklärt und es gibt bislang keinen Konsens über die genaue Lokalisation des Proteins in der Zelle. 


\section{Anhang}

\section{Spastic Paraplegia Rating Scale (SPRS)}

Tab. 12: Spastic Paraplegia Rating Scale.

Das German Network for Hereditary Movement Disorders hat einen Score entwickelt, um spastische Paraplegien nach Schweregraden klassifizieren zu können. Dabei sollte es primär um Praktikabilität gehen, die Kriterien sollten ohne besondere Hilfsmittel oder Geräte im Rahmen einer umfassenden neurologischen Untersuchung beurteilbar sein. Für jedes der 13 Kriterien können maximal 4 Punkte vergeben werden. Ein schwerst betroffener Patient kann einen Score von maximal 52 Punkten erreichen (Schüle et al. 2006).

\begin{tabular}{|c|c|c|c|c|}
\hline 0 Punkte & 1 Punkt & 2 Punkte & 3 Punkte & 4 Punkte \\
\hline \multicolumn{5}{|c|}{ 1) Gehstrecke ohne Pause (anamnestisch, Hilfsmittel erlaubt) } \\
\hline normal, uneingeschränkt & $\begin{array}{l}\text { abnorme Erschöpf ung nach } \\
\text { Gehstrecke von } 500 \mathrm{~m}\end{array}$ & Gehstrecke unter $500 \mathrm{~m}$ & Gehstrecke unter $10 \mathrm{~m}$ & Gehunf ähigkeit \\
\hline \multicolumn{5}{|c|}{ 2) Gangqualität (10 m so schnell w ie möglich hin- und zurück zu gehen) } \\
\hline normal & $\begin{array}{l}\text { milde Steifigkeit, } \\
\text { Rennen möglich }\end{array}$ & $\begin{array}{l}\text { deutlich spastischer Gang, } \\
\text { Behinderung des Rennens }\end{array}$ & $\begin{array}{l}\text { spastischer Gang, } \\
\text { Gehhilfe nötig }\end{array}$ & $\begin{array}{l}\text { auch mit max. Unterstützung } \\
\text { Gehen von } 10 \mathrm{~m} \text { nicht möglich }\end{array}$ \\
\hline \multicolumn{5}{|c|}{ 3) Gehgeschw indigkeit (10 $\mathrm{m}$ hin und zurück) } \\
\hline normal & $\begin{array}{l}\text { leicht eingeschränkt } \\
(10 \mathrm{~m} \geq 5 \mathrm{~s})\end{array}$ & $\begin{array}{l}\text { mittelgradig eingeschränkt } \\
(10 \mathrm{~m} \geq 10 \mathrm{~s})\end{array}$ & $\begin{array}{l}\text { schwer eingeschränkt } \\
(10 \mathrm{~m} \geq 20 \mathrm{~s})\end{array}$ & $\begin{array}{l}\text { Gehen von } 10 \mathrm{~m} \text { nicht möglich, } \\
\text { Dauer } \geq 40 \mathrm{~s}\end{array}$ \\
\hline \multicolumn{5}{|c|}{ 4) Treppensteigen (5 Stufen hinauf - Drehung - 5 Stufen hinunter) } \\
\hline $\begin{array}{l}\text { normal: kein Geländer } \\
\text { nötig }\end{array}$ & $\begin{array}{l}\text { mild beeinträchtigt: } \\
\text { gelegentliche Benutzung des } \\
\text { Geländers }\end{array}$ & $\begin{array}{l}\text { mittelgradig eingeschränkt: } \\
\text { permanentes Festhalten am } \\
\text { Geländer }\end{array}$ & $\begin{array}{l}\text { schwer eingeschränkt: } \\
\text { Hilf estellung/ Hilf smittel benötigt }\end{array}$ & Treppensteigen nicht möglich \\
\hline \multicolumn{5}{|c|}{ 6) Aufstehen vom Stuhl (Arme auf der Brust verschränkt) } \\
\hline normal & $\begin{array}{l}\text { langsam, mehr als ein Versuch } \\
\text { nötig }\end{array}$ & Unterstützung durch die Arme & \begin{tabular}{|l|} 
Tendenz zurückzuf allen, mehrere \\
Versuche nötig, Auf stehen \\
möglich
\end{tabular} & $\begin{array}{l}\text { Auf stehen ohne Hilf e nicht } \\
\text { möglich }\end{array}$ \\
\hline \multicolumn{5}{|c|}{ 7) Spastik Hüftadduktoren (stärker betroffene Seite) } \\
\hline Tonus nicht erhöht & Tonus mild erhöht & $\begin{array}{l}\text { Tonuserhöhung über größten Teil } \\
\text { des Bewegungsradius }\end{array}$ & \begin{tabular}{|l|}
$\begin{array}{l}\text { deutlich erhöhter Muskeltonus, } \\
\text { passive Bewegung schwierig }\end{array}$ \\
\end{tabular} & Bein steif in Adduktion \\
\hline \multicolumn{5}{|c|}{ 8) Spastik Knieflexion (stärker betroffene Seite) } \\
\hline Tonus nicht erhöht & Tonus mild erhöht & $\begin{array}{l}\begin{array}{l}\text { Tonuserhöhung über größten Teil } \\
\text { des Bewegungsradius }\end{array} \\
\end{array}$ & \begin{tabular}{|l|}
$\begin{array}{l}\text { deutlich erhöhter Muskeltonus, } \\
\text { passive Bewegung schwierig }\end{array}$ \\
\end{tabular} & Bein steif in Flexion/ Extension \\
\hline \multicolumn{5}{|c|}{ 9) Schw äche Hüftabduktion } \\
\hline keine Schwäche & milde Schwäche (4/5 n. MRC) & moderate Schwäche $(3 / 5 \mathrm{n}$. MRC) & Schwäche (1-2/5 n. MRC) & Plegie (0/5 n. MRC) \\
\hline \multicolumn{5}{|c|}{ 10) Schw äche Dorsalextension im oberen Sprunggelenk } \\
\hline keine Schwäche & milde Schwäche (4/5 n. MRC) & moderate Schwäche (3/5 n. MRC) & Schwäche (1-2/5 n. MRC) & Plegie (0/5 n. MRC) \\
\hline \multicolumn{5}{|c|}{$\begin{array}{l}\text { 11) Kontakturen untere Extremitäten (Hüfte: Beine in Rückenlage auf Unterlage, Hüftabduktion }>60^{\circ} \text {, Knie: Ober- und Unterschenkel } \\
\text { berühren Unterlage, Fuß: Dorsalextension }>10^{\circ} \text {, Pronation }>10^{\circ} \text { ) }\end{array}$} \\
\hline keine Kontrakturen & $\begin{array}{l}\text { milde, nicht fixierte Kontaktur } \\
\text { eines Gelenks }\end{array}$ & fixierte Kontraktur eines Gelenks & $\begin{array}{l}\text { fixierte Kontraktur von zwei } \\
\text { Gelenken }\end{array}$ & $\begin{array}{l}\text { fixierte Kontraktur von mehr als } 2 \\
\text { Gelenken }\end{array}$ \\
\hline \multicolumn{5}{|c|}{ 12) Schmerzen durch Spastik } \\
\hline keine & \begin{tabular}{|l|}
$<50 \%$ des Tages \\
Intensität $0-3$ VAS \\
\end{tabular} & \begin{tabular}{|l|}
$<50 \%$ des Tagen \\
Intensität 4-10 VAS
\end{tabular} & \begin{tabular}{|l|}
$>50 \%$ des Tages \\
Intensität $0-3$ VAS
\end{tabular} & \begin{tabular}{|l|}
$50 \%$ des Tages \\
Intensität $4-10$ VAS
\end{tabular} \\
\hline \multicolumn{5}{|c|}{ 13) Blasen-/ Mastdarmfunktion } \\
\hline normal & Drang, ohne Inkontinenz & milde Dranginkontinenz & moderate Dranginkontinenz & $\begin{array}{l}\text { Dauerkatheter/ dauerhaf te } \\
\text { Inkontinenz }\end{array}$ \\
\hline
\end{tabular}




\section{Literaturverzeichnis}

Adams BD, Furneaux H, White BA (2007). The micro-ribonucleic acid (miRNA) miR-206 targets the human estrogen receptor- $\alpha(\mathrm{ER} \alpha)$ and represses ER $\alpha$ messenger RNA and protein expression in breast cancer cell lines. Mol Endokrinol 21, 1132-1147.

Aravin AA, Lagos-Quintana M, Yalcin A, Zavolan M, Marks D, Snyder B, Gaasterland T, Meyer J, Tuschl T (2003). The small RNA profile during Drosophila melanogaster development. Dev Cell. $\underline{5}, 337-350$.

Bartel DP (2004). MicroRNAs: Genomics, biogenesis, mechanism, and function. Cell $\underline{116}$, 281-297.

Bartel DP (2009). MicroRNAs: target recognition and regulatory functions. Cell $\underline{136}, 215-$ 233.

Battini R, Fogli A, Borghetti D, Michelucci A, Perazza S, Baldinotti F, Conidi ME, Ferreri MI, Simi P, Cioni G (2011). Clinical and genetic findings in a series of Italian children with pure hereditary spastic paraplegia. Eur J Neurol 18, 150-157.

Beetz C, Schüle R, Deconinck T, Tran-Viet KN, Zhu H, Kremer BPH, Frintz SGM, van Zelst-Stams WAG, Byrne P, Otto S (2008). REEP1 mutation spectrum and genotype/ phenotype correlation in hereditary spastic paraplegia type 31. Brain $\underline{131}$, 1078-1086.

Behan WMH, Maia M (1974). Strümpell's familial spastic paraplegia: genetics and neuropathology. J Neurol Neurosurg Psychiatry $\underline{37}, 8-20$. 
Bentwich I, Avniel A, Karov Y, Aharonov R, Gilad S, Barad O, Barzilai A, Einat P, Einav U, Meiri E (2005). Identification of hundreds of conserved and nonconserved human microRNAs. Nat. Genet $\underline{37}, 766-770$.

Bilen J, Liu N, Burnett BG, Pittman RN, Bonini NM (2006). MicroRNA pathways modulate polyglutamine-induced neurodegeneration. Mol Cell 24, 157-163.

Birnboim HC, Doly J (1979). A rapid alkaline extraction procedure for screening recombinant plasmid DNA. Nucleic Acids Res 24, 1513-1523.

Brendle A, Lei H, Brandt A, Johansson R, Enquist K, Henriksson R, Hemminki K, Lenner P, Försti A (2008). Polymorphisms in predicted microRNA-binding sites in integrin genes and breast cancer: ITGB4 as prognostic marker. Carcinogenesis. 29, 1394-1399.

Chang YF, Imam JS, Wilkinson MF (2007). The nonsense-mediated decay RNA surveillance pathway. Annu Rev Biochem $\underline{76}$, 51-74.

Chomczynski P, Sacchi N (1987). Single-step method of RNA isolation by acid guanidinium thiocyanate-phenol-chloroform extraction. Anal Biochem 162, 156-159.

Clark JM (1988). Novel non-templated nucleotide addition reactions catalyzed by procaryotic and eucaryotic DNA polymerases. Nucleic Acids Res 16, 9677-9686.

De Bot ST, van de Warrenburg BP, Kremer HP, Willemsen MA (2010). Child Neurology: Hereditary spastic paraplegias in children. Neurology $\underline{75}, 75-79$.

Depienne C, Stevanin G, Brice A, Durr A (2007). Hereditary spastic paraplegias: an update. Curr Opin Neurol 20, 674-680. 
De Wet JR, Wood KV, Helinski DR, DeLuca M (1985). Cloning of firefly luciferase cDNA

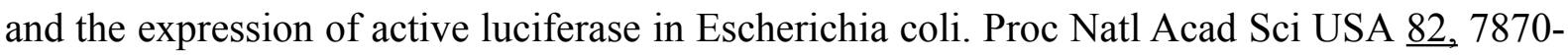
7873.

Didiano D, Hobert O (2006). Perfect seed pairing is not a generally reliable predictor for miRNA-target interactions. Nat Struct Mol Biol 13, 849-851.

Didiano D, Hobert O (2008). Molecular architecture of a miRNA-regualted 3'UTR. RNA $\underline{14}$, $1297-1317$.

Doench JG, Sharp PA (2004). Specifity of microRNA target selection in translational repression. Genes \& Dev 21, 504-511.

Du L, Pertsemlidis A (2011). Cancer and neurodegenerative disorders: pathogenic convergence through microRNA regulation. J Mol Cell Biol. $\underline{3}, 176-180$.

Duning T, Warnecke T, Schirmacher A, Schiffbauer H, Lohmann H, Mohammadi S, Young P, Deppe M (2010). Specific pattern of early white-matter changes in pure hereditary spastic paraplegia. Mov Disord. 25,1986-1992.

Erichsen AK, Koht J, Stray-Pedersen A, Abdelnoor M, Tallaksen CME (2009). Prevalence of hereditary ataxia and spastic paraplegia in southeast Norway: a populationbased study. Brain 132, 1577-1588.

Finsterer J (2003). Hereditäre spastische Paraplegien. Nervenarzt 쑤, 497-504

Fritsch P: Dermatologie Venerologie. 2. Auflage, Springer Verlag, Berlin 2004. 
Fujikawa H, Fujimoto A, Farooq M, Ito M, Shimomura Y (2012). Characterization of the human hair keratin-associated protein 2 (KRTAP2) gene family. J Invest Dermatol 132, 18061813

Gascon E, Gao FB (2012). Cause or Effect: Misregulation of microRNA Pathways in Neurodegeneration.Front Neurosci. $\underline{6}, 48$.

Goizet C, Depienne C, Benard G, Boukhris A, Mundwiller E, Solé G, Coupry I, Pilliod J, Martin-Négrier ML, Fedirko E (2011). REEP1 mutations in SPG31: frequency, mutational spectrum, and potential association with mitochondrial morpho-functional dysfunction. Hum Mutat $\underline{32}, 1118-1127$.

Guidubaldi A, Piano C, Santorelli FM, Silvestri G, Petracca M, Tessa A, Bentivoglio AR (2011). Novel mutations in SPG11 cause hereditary spastic paraplegia associated with earlyonset levodopa-responsive parkinsonism. Mov Disord 26, 553-556.

Han J, Lee Y, Yeom KH, Kim YK, Jin H, Kim VN (2004). The Drosha-DGCR8 complex in primary microRNA processing. Genes Dev $\underline{18}, 3016-3027$.

Hanahan D (1983). Studies on transformation of Escherichia coli with plasmids. J Mol Biol $\underline{166}, 557-580$.

Hanke M, Kausch I, Dahmen G, Jocham D, Warnecke JM (2007). Detailed technical analysis of urine RNA-based tumor diagnostics reveals ETS2/ urokinase plasminogen activator to be a novel marker for bladder cancer. Clin Chem 53, 2070-2077.

Harding AE (1983). Classification of the hereditary ataxias and paraplegias. Lancet $\underline{1}, 1151$ 1155. 
Harding AE (1993). Hereditary spastic paraplegias. Seminars in Neurology $\underline{13}$, 333-336

Hassan O, Ahmad A, Sethi S, Sarkar FH (2012). Recent updates on the role of microRNAs in prostate cancer. J Hematol Oncol $\underline{5}, 9$.

Hautmann R, Huland H: Urologie. 3.Auflage, Springer Medizin Verlag, Heidelberg 2006.

Hedera P, Eldevik OP, Maly P, Rainier S, Fink JK (2005). Spinal cord magnetic resonance imaging in autosomal dominant hereditary spastic paraplegia. Neuroradiology $\underline{47}, 730-734$.

Hewamadduma C, McDermott C, Kirby J, Grierson A, Panayi M, Dalton A, Rajabally Y, Shaw P (2008). New pedigrees and novel mutation expand the phenotype of REEPIassociated hereditary spastic paraplegia (HSP). Neurogenetics $\underline{10}, 105-110$.

Hourani R, El-Hajj T, Barada WH, Hourani M, Yamount BI (2009). MR imaging findings in autosomal recessive hereditay spastic paraplegia. Am J Neuroradiol $\underline{30}$, 936-940.

Hu J, Shibata Y, Zhu PP, Voss C, Rismanchi N, Prinz WA, Rapoport TA, Blackstone C (2009). A class of dynamin-like GTPases involved in the generation of tubular ER network. Cell $\underline{138}, 549-561$.

Huang Z, Fasco MJ, Kaminsky LS (1996). Optimization of DNase I removal of contaminating DNA from RNA for use in quantitative RNA-PCR. Biotechniques $\underline{20}, 1012-$ 1020.

Hutchison CA 3rd, Phillips S, Edgell MH, Gillam S, Jahnke P, Smith M (1978). Mutagenesis at a specific position in a DNA sequence. J Biol Chem $\underline{253}, 6551-6560$ 
Hutvágner G, McLachlan J, Pasquinelli AE, Bálint E, Tuschl T, Zamore PD (2001). A cellular function for the RNA-interference enzyme Dicer in the maturation of the let-7 small temporal RNA. Science. 293, 834-838.

Jainchill JL, Aaronson SA, Todaro GJ (1969). Murine sarcoma and leukemia viruses: assay using clonal lines of contact-inhibited mouse cells. J Virol $\underline{4}, 549-553$.

Johnson SM, Grosshans H, Shingara J, Byrom M, Jarvis R, Cheng A, Labourier E, Reinert KL, Brown D, Slack FJ (2005). RAS is regulated by the let-7 microRNA family. Cell $\underline{120}, 635-647$.

Kim VN (2005). Small RNAs: classification, biogenesis, and function. Mol Cells $\underline{19}$, 1-15.

Krol J, Loedige I, Filipowicz W (2010). The widespread regulation of microRNA biogenesis, function and decay. Nat Rev Genet 11, 597-610.

Lacks S, Greenberg B (1975). A deoxyribonuclease of Diplococcus pneumoniae specific for methylated DNA. J Biol Chem $\underline{250}$, 4060-4066.

Lacks S, Greenberg B (1977). Complementary specificity of restriction endonucleases of Diplococcus pneumoniae with respect to DNA methylation. J Mol Biol 114, 153-168.

Ladewig E, Okamura K, Flynt AS, Westholm JO, Lai EC (2012). Discovery of hundreds of mirtrons in mouse and human small RNA data. Genome Res. 22, 1634-1645.

Lagos-Quintana M, Rauhut R, Lendeckel W, Tuschl T (2001). Identification of novel genes coding for small expressed RNAs. Science. 294, 853-858. 
Lagos-Quintana M, Rauhut R, Yalcin A, Meyer J, Lendeckel W, Tuschl T (2002). Identification of tissue-specific microRNAs from mouse. Curr Biol $\underline{12}$, 735-9.

Lagos-Quintana M, Rauhut R, Meyer J, Borkhardt A, Tuschl T (2003). New microRNAs from mouse and human. RNA $\underline{9}, 175-179$.

Lee RC, Feinbaum RL, Ambros V (1993). The C. elegans heterochronic gene lin-4 encodes small RNAs with antisense complementarity to lin-14. Cell. $\underline{75}$, 843-854.

Lee RC, Ambros V (2001). An extensive class of small RNAs in Caenorhabditis elegans. Science 294, 862-864.

Lee Y, Jeon K, Lee JT, Kim S, Kim VN (2002). MicroRNA maturation: stepwise processing and subcellular localization. EMBO J $\underline{21}, 4663-4670$.

Lee Y, Ahn C, Han J, Choi H, Kim J, Yim J, Lee J, Provost P, Rådmark O, Kim S, Kim VN (2003). The nuclear RNase III Drosha initiates microRNA processing. Nature $\underline{425}, 415$ 419.

Li B, Hartono C, Ding R, Sharma VK, Ramaswamy R, Qian B, Serur D, Mouradian J, Schwartz JE, Suthanthiran M (2001). Noninvasive diagnosis of renal-allograft rejection by measurement of messenger RNA for perforin and granzyme B in urine. N Engl J Med $\underline{344}$, 947-954.

Li M, Marin-Muller C, Bharadwaj U, Chow KH, Yao Q, Chen C (2008). MicroRNAs: Control and loss of control in human physiology and disease. World J Surg $\underline{33}, 667-684$.

Li Y, St John MA, Zhou X, Kim Y, Sinha U, Jordan RC, Eisele D, Abemayor E, Elashoff D, Park NH, Wong DT (2004). Salivary transcriptome diagnostics for oral cancer detection. 
Clin Cancer Res $\underline{10}, 8442-8450$.

Lim LP, Lau NC, Weinstein EG, Abdelhakim A, Yekta S, Rhoades MW, Burge CB, Bartel DP (2003). The microRNAs of Caenorhabditis elegans. Genes Dev. $\underline{8}, 991-1008$.

Linch CA (2009). Degeneration of nuclei and mitochondria in Human Hairs. J Forensic Sci 54, 346-349

Linch CA, Whiting DA, Holland MM (2001). Human hair histogenesis for the mitochondrial DNA forensic scientist. J Forensic Sci $\underline{46}, 844-853$

Liu SG, Che FY, Heng XY, Li FF, Huang SZ, Lu DG, Hou SJ, Liu SE, Wang Q, Wang HP (2009). Clinical and genetic study of a novel mutation in the REEP1 gene. Synapse $\underline{63}$, 201-205.

Lo DC, Hughes RE: Neurobiology of Huntington's disease: applications to drug discovery. CRC Press, Boca Raton, Florida, USA 2011.

Lorrain M (1898). Contribution à l'étude de la paraplégie spasmodique familiale. Thesis de Paris.

Marshall GR, Feng JA, Kuster DJ (2008). Back to the future: ribonuclease A. Biopolymers 90, 259-277.

McCorquodale DS III, Ozomaro U, Huang J, Montenegro G, Kushman A, Citrigno L, Price J, Speziani F, Pericak-Vance MA, Züchner S (2011). Mutation screening of spastin, atlastin, and REEP1 in hereditary spastic paraplegia. Clin Genet $\underline{79}, 523-530$. 
McDermott CJ, White K, Bushby K, Shaw PJ (2000). Hereditary spastic paraparesis: A review of new developments. J Neurol Neurosurg Psychiatry $\underline{69}, 150-160$.

McDermott CJ, Burness CE, Kirby J, Cox LE, Rao DG, Hewamadduma C, Sharrack B, Hadjivassiliou M, Chinnery PF, Dalton A, Shaw PJ (2006). Clinical features of hereditary spastic paraplegia due to spastin mutation. Neurology $\underline{67} .45-51$.

McMonagle P, Webb S, Hutchinson M (2002). The prevalence of ,pure“ autosomal dominant hereditary spastic paraparesis in the island of Ireland. J Neurol Neurosurg Psychiatry $\underline{72}, 43-46$

Monrad P, Renaud DL (2011). Severe spinal cord atrophy associated with spastic paraparesis. Pediatr Neurol $\underline{44}, 75-77$.

Montpetit SA, Fitch IT, O'Donnell PT (2005). A simple automated instrument for DNA extraction in forensic casework. J Forensic Sci $\underline{50}$, 555-563.

Navazesh M (1993). Methods for collecting saliva. Ann N Y Acad Sci 694, 72-77.

Olsen PH, Ambros V (1999). The lin-4 regulatory RNA controls developmental timing in Caenorhabditis elegans by blocking LIN-14 protein synthesis after the initiation of translation. Dev Biol 216, 671-680.

Okamura K, Hagen JW, Duan H, Tyler DM, Lai EC (2007). The mirtron pathway generates microRNA-class regulatory RNAs in Drosophila. Cell 130, 89-100.

Opel KL, Fleishacker EL, Nicklas JA, McCord BR (2008). Evaluation and quantification of nuclear DNA from human telogen hairs. J Forensic Sci 53, 853-857. 
Ow DW, De Wet JR, Helinski DR, Howell SH, Wood KV, Deluca M (1986). Transient and stable expression of the firefly luciferase gene in plant cells and transgenic plants. Science $\underline{234}, 856-859$.

Park NJ, Li Y, Yu T, Brinkman BM, Wong DT (2006). Characterization of RNA in saliva. Clin Chem $\underline{52}, 988-994$.

Park SH, Zhu PP, Parker RL, Blackstone C (2010). Hereditary spastic paraplegia proteins REEP1, spastin, and atlastin-1 coordinate microtubule interactions with the tubular ER network. J Clin Invest 120, 1097-1110.

Pasquinelli AE (2012). MicroRNAs and their targets: recognition, regulation and an emerging reciprocal relationship. Nat Rev Genet. 13, 271-282.

Place RF, Li LC, Pookot D, Noonan EJ Dahiya R (2008). MicroRNA-373 induces expression of genes with complementary promoter sequences. Proc Natl Acad Sci $\underline{105}, 1608$ 1613.

Rajewsky N (2006). L(ou)sy miRNA targets? Nat Struct Mol Biol 13, 754-755.

Rousseau M. Evaluating the role of p.S44L variant in SPG4 pathogenesis - To determine the effect of miRNA binding sites on the pathogenesis of SPG31 (miR-691 \& miR-140). Bachelor Thesis, Georg-August Universität, Göttingen 2010.

Ruby JG, Jan CH, Bartel DP (2007). Intronic microRNA precursors that bypass Drosha processing. Nature $\underline{448}, 83-86$

Saiki RK, Gelfand DH, Stoffel S, Scharf SJ, Higuchi R, Horn GT, Mullis KB, Erlich HA (1988). Primer-directed enzymatic amplification of DNA with a thermostable DNA 
polymerase. Science $\underline{239}, 487-491$.

Saito H, Kubota M, Roberts RW, Chi Q, Matsunami H (2004). RTP family members induce functional expression of mammalian odorant receptors. Cell. $\underline{119}, 679-91$.

Salinas S, Carazo-Salas RE, Proukakis C, Schiavo G, Warner TT (2007). Spastin and

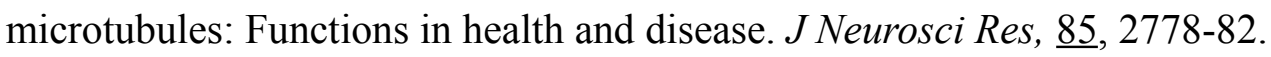

Salinas S, Proukakis C, Crosby A, Warner TT (2008). Hereditary spastic paraplegia: clinical features and pathogenetic mechanisms. Lancet Neurol $\underline{7}, 1127-1138$.

Salvatore M, Magrelli A, Taruscio D (2011). The role of microRNAs in the biology of rare diseases. Int. J. Mol. Sci. 12, 6733-6742.

Sambrook J, Fritsch EF, Maniatis T: Molecular cloning: a laboratory manual. Cold Spring Harbor Laboratory Press, New York, USA 1989.

Sanger F, Nicklen S, Coulson AR (1977). DNA sequencing with chain-terminating inhibitors. Proc Nati Acad Sci 74, 5463-5467.

Sauter S, Neesen J, Paulus W, Engel W (2002). Hereditäre spastische Paraplegie. Dtsch Arztebl 99, A 434-440.

Schlang KJ, Arning L, Epplen JT, Stemmler S (2008). Autosomal dominant hereditary spastic paraplegia: Novel mutations in the REEP I gene (SPG31). BMC Med Genet $\underline{9}$, 71-74.

Schouten JP, McElgunn CJ, Waaijer R, Zwijnenburg D, Diepvens F, Pals G (2002). Relative quantification of 40 nucleic acid sequences by multiplex ligation-dependent probe 
amplification. Nucleic Acids Res $\underline{30}$, e57.

Schüle R, Holland-Letz T, Klimpe S, Kassubek j, Klopstock t, Mall V, Otto S, Winner B, Schöls L (2006). The spastic paraplegia rating scale (SPRS) A reliable and valid measure of disease severity. Neurology $\underline{67}, 430-434$.

Scuderi C, Fichera M, Calabrese G, Elia M, Amato C, Savio M, Borgione E, Vitello GA, Muscumeci SA (2008). Posterior fossa abnormalities in hereditary spastic paraparesis with spastin mutations. J Neurol Neurosurg Psychiatry $\underline{80}$, 440-443.

Sellner LN, Taylor GR (2004). MLPA and MAPH: New techniques for detection of gene deletions. Hum Mutat 23, 413-419.

Shen J, Ambrosone CB, Zhao H (2008). Novel genetic variants in microRNA genes and familial breast cancer. Int J Cancer 124, 1178-1182.

Silva MC, Coutinho P, Pinheiro CD, Neves JM, Serrano P. (1997). Hereditary ataxias and spastic paraplegias: Methodological aspects of a prevalence study in Portugal."J Clin Epidemiol 50, 1377-1384.

Slack FJ, Basson M, Liu Z, Ambros V, Horvitz HR, Ruvkun G (2000). The lin-41 RBCC gene acts in the $\mathrm{C}$. elegans heterochronic pathway between the let-7 regulatory RNA and the LIN-29 transcription factor. Mol Cell $\underline{5}, 659-669$.

Somasundaram S, Raghavendra S, Singh A, Kesavadas C, Nair M (2007). Hereditary spastic paraplegia with a thin corpus callosum. Pediatr Radiol 37, 503-505

Speckmann EJ, Hescheler J, Köhling R: Physiologie. 5. Auflage, Elsevier GmbH Urban \& Fischer, München 2008. 
Spivack SD, Hurteau GJ, Jain R, Kumar SV, Aldous KM, Gierthy JF, Kaminsky LS (2004). Gene-environment interaction signatures by quantitative mRNA profiling in exfoliated buccal mucosal cells.“ Cancer Res $\underline{64}$, 6805-6813.

Stromillo ML, Malandrini A, Dotti MT, Bataglini M, Borgogni F, Tessa A, Storti E, Denora PS, Santorelli FM, Gaudiano C (2011). Structural and metabolic damage in brains of patients with SPG11-related spastic paraplegia as detected by quantitative MRI. J Neurol $\underline{258}, 2240-2247$

Strümpell A (1880). Beiträge zur Pathologie des Rückenmarks. Arch Psychiatr Nervenkr $\underline{10}$, 676-717.

Suenaga E, Nakamura H (2005). Evaluation of three methods for effective extraction of DNA from human hair. J Chromatogr B Analyt Technol Biomed Life Sci. 2ㅜㅇ, 137-141.

Szabo S, Jaeger K, Fischer H, Tschachler E, Parson W, Eckhard L (2011). In situ labeling of DNA reveals interindividual variation in nuclear DNA breakdown in hair and may be useful to predict success of forensic genotyping of hair. Int J Legal Med $\underline{126}, 63-70$

Thomson DW, Bracken CP, Goodall GJ (2011). Experimental strategies for microRNA target identification. Nucleic Acids Res $\underline{39}$, 6845-6853.

Vasudevan S, Tong Y Steitz JA (2007). Switching from repression to activation: microRNAs can up-regulate translation. Science $\underline{318}$ 1931-1934.

Vella MC, Choi EY, Lin SY, Reinert K, Slack FJ (2004a). The C. elegans microRNA let-7 binds to imperfect let-7 complementary sites from the lin-41 3' UTR. Genes \& Dev $\underline{18}, 132-$ 137. 
Vella MC, Reinert K, Slack FJ (2004b). Architecture of a validated microRNA target interaction. Chem Biol 11, 1619-1623.

Wadhwa N, Jatawa SK, Tiwari A (2012). Non-invasive urine based tests for the detection of bladder cancer. J Clin Pathol $\underline{65}$, 970-975.

Weikert S, Christoph F, Schrader M, Krause H, Miller K, Müller M (2005). Quantitative analysis of survivin mRNA expression in urine and tumor tissue of bladder cancer patients and its potential relevance for disease detection and prognosis. Int J Cancer $\underline{116}, 100-104$.

Züchner S (2007). The genetics of hereditary spastic paraplegia and implications for drug therapy. Expert Opin Pharmacother $\underline{8}, 1433-1439$.

Züchner S, Wang G, Tran-Viet KN, Nance MA, Gaskell PC, Vance JM, Ashley-Koch AE, Periak-Vance MA (2006). Mutations in the Novel Mitochondrial Protein REEP1 Cause Hereditary Spastic Paraplegia Type 31. Am J Hum Genet 79, 365-369. 


\section{Danksagung}

Mein herzlicher Dank gilt Herrn Prof. Dr. med. Dr. h.c. Engel für die Möglichkeit, meine Promotion unter seiner Leitung durchführen zu können.

Ebenfalls danken möchte ich meinen Betreuern Herrn Dr. rer. nat. Ashraf-ul Mannan und Herrn Dr. med. Moneef Shoukier für die Unterstützung, die Geduld und Beantwortung all meiner Fragen.

Für die lehrreichen Gespräche, die Einarbeitung und die Hilfe bei der Versuchsplanung bin ich weiterhin Herrn Dr. rer. nat. Krishna Pantakani, Herrn Chiranjeevi Bodda, Frau Dr. rer. nat. Silke Kaulfuß, Frau Dr. med. Silke Pauli, den Kolleginnen aus der DNA-Diagnostik und natürlich meinen lieben Mit-Promovierenden zu Dank verpflichtet. 